\title{
THE EFFECT OF HEAT TREATMENT ON METALLURGICAL AND MECHANICAL PROPERTIES OF WELD METAL IN A LEAD-0.06 WEIGHT PERCENT CALCIUM ALLOY
} W. W. Canary

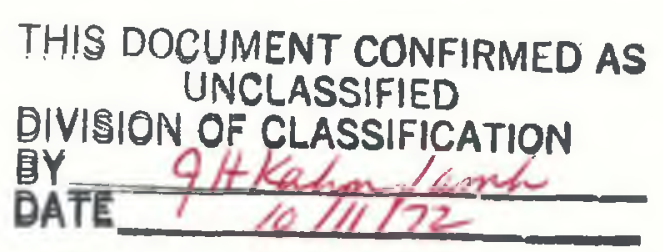




\section{DISCLAIMER}

This report was prepared as an account of work sponsored by an agency of the United States Government. Neither the United States Government nor any agency Thereof, nor any of their employees, makes any warranty, express or implied, or assumes any legal liability or responsibility for the accuracy, completeness, or usefulness of any information, apparatus, product, or process disclosed, or represents that its use wouid not infringe privately owned rights. Reference herein to any specific commercial product, process, or service by trade name, trademark, manufacturer, or otherwise does not necessariiy constitute or impiy its endorsement, recommendation, or favoring by the United States Government or any agency thereof. The views and opinions of authors expressed herein do not necessariiy state or reflect those of the United States Government or any agency thereof. 


\section{DISCLAIMER}

Portions of this document may be illegible in electronic image products. Images are produced from the best available original document. 
Printed in the United States of America. Available from National Technical Information Service

U.S. Department of Commerce

5285 Port Royal Road, Springfield, Virginia 22151

Price: Printed Copy $\$ 3.00$; Microfiche $\$ 0.95$

This report was prepared as an account of work sponsored by the United States Government. Neither the United States nor the United States Atomic Energy Commission, nor any of their employees, nor any of their contractors, subcontractors, or their employees, makes any warranty, express or implied, or assumes any legal liability or responsibility for the accuracy, completeness or usefulness of any information, apparatus, product or process disclosed, or represents that its use would not infringe privately owned rights.

Reference to a company or product name does not imply approval or recommendation of the product by Union Carbide Corporation or the US Atomic Energy Commission to the exclusion of others that may meet specifications. 


\title{
THE EFFECT OF HEAT TREATMENT ON METALLURGICAL AND MECHANICAL PROPERTIES OF WELD METAL IN A LEAD-0.06 WEIGHT PERCENT CALCIUM ALLOY
}

W. W. Canary

\section{Oak Ridge .Y-12 Plant}

P.O. Box Y, Oak Ridge, Tennessee 37830

\begin{abstract}
operated for the U.S. ATOMIC ENERGY COMMISSION bY UNION CARBIDE CORPORATION-NUCLEAR DIVISION under Contract W-7405-eng-26
\end{abstract}

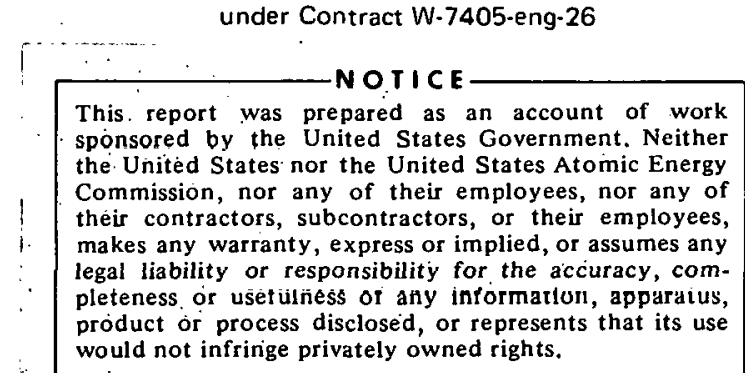

would not infringe privately owned rights.

This report is based on a study by the author as partial fulfillment of requirements for the degree of Master of Science in Metallurgical Engineering from The University of Tennessee.

Date Issued - September 29, 1972 
The purpose of this investigation was to determine the welding parameters necessary, to produce a metallurgically sound weld with chemistry similar to the 0.06 weight percent calcium base metal and to determine the effect of heat treatment on metallurgical and mechanical properties of the weld metal and heat-affected zone.

The gas tungsten-arc alternating current welding process was determined to be a welding process capable of welding the lead-calcium alloy without producing calcium losses in the weld metal. The process permitted the addition of filler metal, promoted complete fusion, and resulted in a smooth weld bead.

Mechanical properties, including hardness and tensile strength, were first characterized on base metal solution heat treated and room temperature aged and solution heat treated and aged at $100^{\circ} \mathrm{C}$. A maximum hardness of approximately 13.0 BHN was obtained for both aging treatments. A maximum ultimate tensile strength of approximately 5000 ps $i$ and a maximum yield strength of approximately 2600 ps $i$ was reached for base metal.

Weld metal was determined to respond in a manner similar to basse mețal when similarly heat treated and aged. A maximum hardness of approximately $12.5 \mathrm{BHN}$ was reached for both the room temperature age and the $100^{\circ} \mathrm{C}$ age. A maximum ultimate tensile strength of approximately $5000 \mathrm{psi}$ and a maximum yield strength of approximately 3000 psi was reached for weld metal. 
Weld metal in the as-welded and room temperature aged condition was also found to respond to hardness and tensile strength increases in a manner similar to the base metal and weld metal solution heat treated and room temperature aged.

Metallographic analysis, transverse-weld tensile data, and microhardness data did not indicate any degradation of properties in the heat-affected zone. Because the lead-calcium alloy is soft and. readily oxidizes, metallographic analysis was difficult. The microstructure did not reveal the solidification history. An electron microprobe analysis did not reveal discrete areas rich in calcium. The analysis did, however, indicate an average calcium content of 0.04 to 0.07 weight percent. Analysis using the scanning electron microscope did not reveal the solidification history. The microscope, however, aided in characterizing isolated porosity and oxidation. 


\section{ACKNOWLEDGEMENTS}

The author is grateful to his thesis advisor, Dr.C. D. Lundin, for his guidance and helpful criticism during this investigation and for his assistance in preparing this manuscript. He expresses his appreciation to the management of the 0ak Ridge $Y-12$ Plant for their approval and support of his research program.

Thanks are extended to the following members of the $Y-12$ Plant who contributed to the success of this research: H. C. East and M. A. Butner for metallography work, C. D, Sțevenson for microprobe work, R. K. Bennett for electron microscopy and D. L. Brown and staff for chemical analysis.

The author is indebted to F. B. Grantham for typing this manuscript and the Technical Information Services Department for assistance in preparing this manuscript.

Thls research was performed at the Oak Ridge $Y=12$ Plant which is operated by the Nuclear Division, Union Carbide Corporation for the U. S. Atomic Energy Commission. 
TABLE OF CONTENTS

CHAPTER

PAGE

I. INTRODUCTION ANB HISTORICAL REVIEW............. I Introduction.................. . . 1 Historical Review ................ 3

The Lead-Calcium System ............ . . 3

Heat Treatment of Lead-Calcium Alloys . ...... 5

Welding Lead-Calcium Alloys........... 7

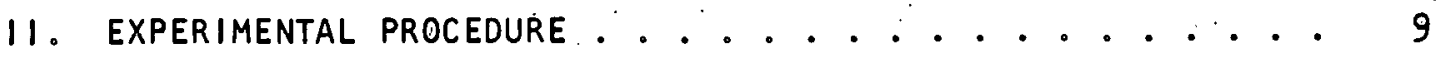

Material Preparation .............. 9

Welding Procedure ................. 11

Chemical Analysis ................. 18

Heat Treatment and Aging ........... 18

Hardness and Tensile Strength Measurements . . . . . 19

Macrohardness ................. . 19

Microhardness ............... . . 19

Tensile Strength . . . . . . . . . . . . 20

Metallography .................. 20

Electron Microprobe Analysis . . . . . . . . 20

Scanning Electron Microscopy . . . . . . . . . 22

Safety...................... 22

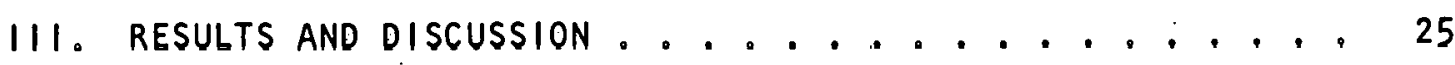

Welding the Lead-Calcium Alloy ............ 25 


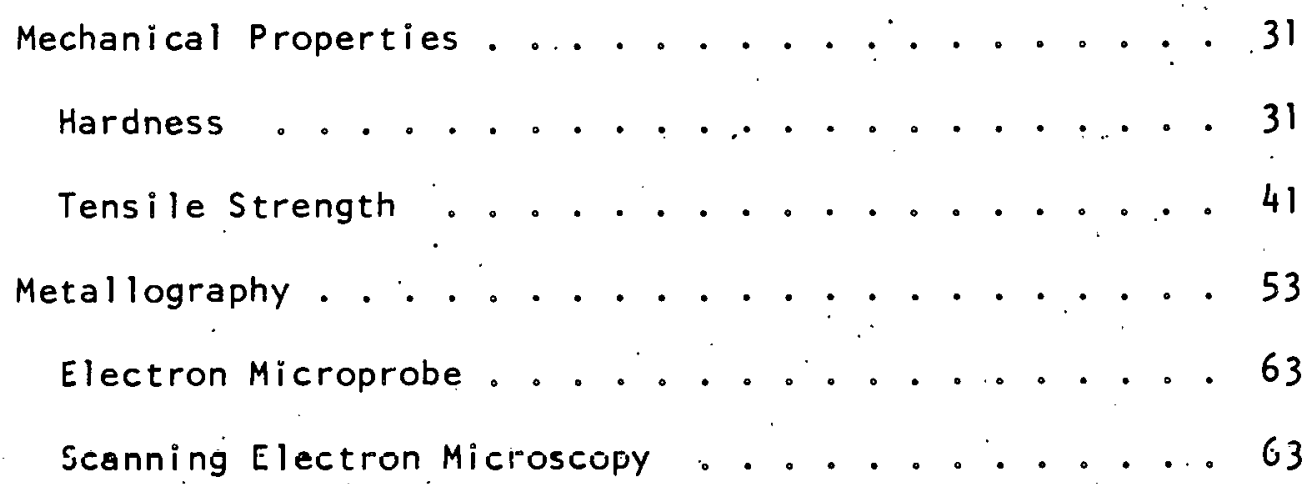

IV. CONCLUSIONS AND RECOMMENDATIONS . . . . ...... 69

Conclusions . . . . . . . . . . . . . . 69

Welding.................... 69

Properties ................ . 69

Summary .................. 71

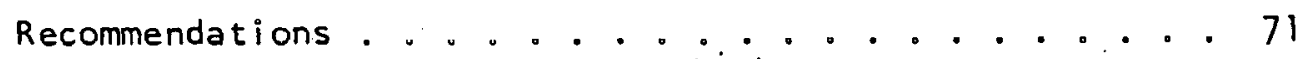

LIST OF REFERENCES ..................... . . 72

APPENDIXES ....................... 75

A. HARDNESS CONVERSION . . . . . . . . . . . . . . . . . . . . 76

B. CALCIUM CONTENT IN BASE METAL COUPONS . . . . . . . 78

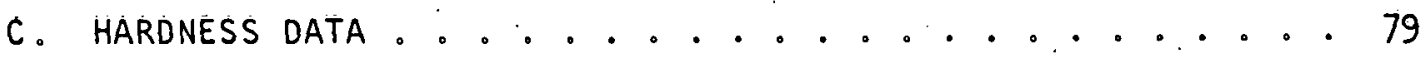

D. TENSILE DATA ..................... 91

VITA .......................... 98 
1. Gross Chemical and Impurity Analysis of the Nominal Lead-0.06 Weight Percent Calcium Used in This Investigation ...................... 10

11: Parameters Used to Weld Lead-Calcium Plate . . . . . 17

111. Calcium Content of Weld Metal Coupons Used for Hardness and Tensile Strength Evaluation, Weight Percent....

B-1. Calcium Content of Base Metal Coupons Used for Hardness and Tensile Strength Evaluation, Weight Percent . . . 78

C-1. Hardness at Various Aging Times for Base Metal Samples Solution Heat Treated at $300^{\circ} \mathrm{C}$ for the Times Indicated, Water Quenched and Room Temperature Aged . . . . . 79

C-2. Hardness at Various Aging Times for Base Metal Samples Solution Heat Treated at $300^{\circ} \mathrm{C}$ for Two Hours, Water Quenched, Aged at $100^{\circ} \mathrm{C}$ for the Time Indicated and Followed by a Room Temperature Age . . . . . . .

C-3. Hardness at Various. Aging Times for Weld Metal Samples Solution Heat Treated at $300^{\circ} \mathrm{C}$ for the Times Indicated, Water Quenched and Room Temperature Aged . . . . . .

C-4. Hardness at Various Aglng Times for Weld Metal Samples Solution Heat Treated at $300^{\circ}$ C for. Two Hours, Water Quenched, Aged at $100^{\circ} \mathrm{C}$ for the Times Indicated and Followed by a Room Temperature Age . . . . . . . 
TABLE

C-5. Hardness at Various Aging Times for Weld Metal Samples in the As-Welded and Room Temperature Aged Condition ... .

c-6. Hardness Traverse in an Initially Fully Hardened Base Metal in the As-Welded Condition, Two Weeks after Welding ................... 90

D-I. Tensile Strength at Various Aging Times for Base Metal Samples Solution Heat Treated at $300^{\circ} \mathrm{C}$ for Two Hours, Water Quenched and Room Temperature Aged ....... 91

D-2. Tensile Strength at Various Aging Times for Base Metal Samples Solution Heat Treated at $300^{\circ} \mathrm{C}$ for Two Hours, Water Quenched and Aged at $100^{\circ} \mathrm{C}$..........

D-3. Tensile Strength at Various Aging Times for LongitudinalWeld Metal Samples Solution Heat Treated at $300^{\circ} \mathrm{C}$ for Two Hours, Water Quenched and Room Temperature Aged . .

D-4. Tensile Strength at Varioue Aging Times for Longiturinal-. Weld Metal Samples Solution Heat Treated at $300^{\circ} \mathrm{C}$ for Two Hours, Water Quenched and Aged at $100^{\circ} \mathrm{C}$. . . . . 94 D-5. Tensile Strength at Various Aging Times for TransverseWeld Metal Samples Solution Heat Treated at $300^{\circ} \mathrm{C}$ for Twö llours, water Quenched and Room Temperatura Aged. . 95

D-6. Tensile Strength at Various Aging Times for TransverseWeld Metal Samples Solution Heat Treated at $300^{\circ}$. C for Two Hours, Water Quenched and Aged at $100^{\circ} \mathrm{C}$. . . . . 96

D-7. Tensile Strength at Various Aging Times for Welded Samples in the As-Welded and Room Temperature Aged Condition . . 97 
i. Lead-Calcium Binary Phase Diagram . . . . . . ... 4

2. Joint Geometry Used in This Investigation . . . . . . 12

3. Welding Fixture Used in This Investigation ........ 13

4. Lead-Calcium Welding Specimens in the Welding Fixture. . . 14

5. The Templet Used to Align the Welding Coupons, Copper

Chill Bars and Aluminum Hold-Down Bar ......... 15

6. Scraping Tool Used to Clean the Welding Coupon Surface

Prior to Welding ...................... 16

7. Tensile Specimen Used in. This Evaluation ........... 21

8. Lead Vapor Flow Pattern During Welding . . . . . . . 23

9. Hardness Versus Aging Time for Base Metal Samples Solution

Heat Treated at $300^{\circ} \mathrm{C}$ for Different Times, Water

Quenched, and Room Temperature Aged ......... 33

10. Hardness Versus Aging Time at the Elevated Aging Tem-

perature for Base Metal Samples Solution Heat Treated

at $300^{\circ} \mathrm{C}$ for Two Hours, Water Quenched, and Aged at

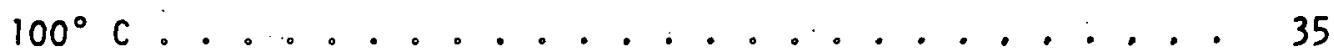

11. Hardness Versus Aging Time for Weld Samples Solution Heat

Treated at $300^{\circ}$ C for Different Times, Water Quenclied, and Room Temperature Aged ............. 36 
FIGURE

PAGE

12. Hardness Versus Aging Time at the Elevated Aging Tem-

perature for Weld Metal Samples Solution Heat Treated

at $300^{\circ} \mathrm{C}$ for Two Hours, Water Quenched, and Aged at

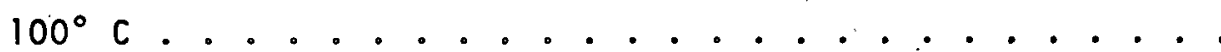

13. Hardness Versus Aging Time for Weld Metal in the As-

Welded, and Room Temperațure Aged Condition. . . . . . 40

14. Hardness Traverse in Initially Fully Hardened Base Metal

in the As-Welded Condition. Two Weeks After Welding . . 42

15. Tensile Strength Versus Aging Time for Base Metal Samples

Solution Heat Treated at $300^{\circ} \mathrm{C}$ for Two Hours, Water

Quenched, and Room Temperature Aged . . . . . . . . 44

16. Tensile Strength Versus Aging Time for Base Metal Samples

Solution Heat Treated at $300^{\circ} \mathrm{C}$ for Two Hours, Water

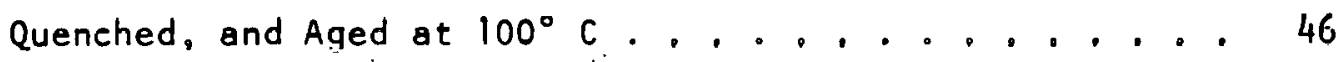

17. Tensile Strength Versus Aging Time for Longitudinal-Weld

Metal Samples Solution Heat Treated at $300^{\circ} \mathrm{C}$ for Two

Hours, Water Quenched, and Room Temperature Aged . . . 47

18. Tensile strength Versus $n g i n g ~ T i m e$ for Longitudinal-Weld

Metal Samples Solution Heat Treated at $300^{\circ} \mathrm{C}$ for Two

Hours, Water Quenched, and Aged at $100^{\circ} \mathrm{C}$. . . . . . 49

19. Tensile Strength Versus Aging Time for Transverse-Weld

Metal Samples Solution Heat Treated at $300^{\circ} \mathrm{C}$ for Two

Hours, Water Quenched, and Room Temperature Aged . . . 
20. Tensile Strength Versus Aging Time for Transverse-Weld Metal Samples Solution Heat Treated at $300^{\circ} \mathrm{C}$ for Two Hours, Water Quenched, and Aged at $100^{\circ} \mathrm{C}$. . . . . . 52

21. Photomicrograph of Base Metal in a Welded Specimen Treated at $300^{\circ} \mathrm{C}$ for Two Hours, Water Quenched, and Room Temperature Aged for Two Weeks (Acetic Acid, Hydrogen Peroxide and Ethyl Alcohol) . . . . . . . . 56

22. Photomicrograph of Weld Metal Solution Heat Treated at $300^{\circ} \mathrm{C}$ for Two Hours, Water Quenched, and Room Temperature Aged for Two Weeks. (Acetic Acid, Hydrogen Peroxide and Ethyl Alcohol) ..............

23. Photomicrograph of. Base Metal in a Welded Specimen Solution Heat Treated at $300^{\circ} \mathrm{C}$ for Two Hours, Water Quenched, and Aged at $100^{\circ} \mathrm{C}$ for 48 Hours (Acetic Acid, Hydrogen Peroxide and Ethyl Alcohol) . . . . . . . 59

24. Photomicrograph of Weld Metal Solution Heat Treated at $300^{\circ} \mathrm{C}$ for Two Hours, Water Quenched, and Aged at $100^{\circ} \mathrm{C}$ for 48 Hours (Acetic Acid, Hydrogen Peroxide and Ethyl. Alcohol).......................

25. Photomicrograph of Initially Fully Hardened Base Metal in a Welded Specimen in the As-Welded Condition, Room, Temperature Aged for Two Weeks (Acetic Acid, Hydrogen Peroxide and Ethyl Alcohol) . . . . . . . . . . 
26. Photomicrograph of Weld. Metal in the As-Welded Condition,

Room Temperature Aged for Two Weeks (Acetic Acid,

Hydrogen Peroxide and Ethyl A.lcohol) ......... 62

27. Scanning Electron Micrograph of a Fractured. Base Metal

Tensile Coupon $(300 x)$. . . . . . . . . . 64

28. Scanning Electron Micrograph of a Fractured Weld Metal

Tensile Coupon $(300 x)$. . ............. 65

29. Scanning Electron Micrograph of an Isolated Pore (1000x) . . 67

30. Scanning Electron Micrograph of Area Just Below the Weld

Root in Unfused Metal (1000x) ........... 68

A-1. The Brinell Hardness Number as a Function of Depth of Indentation for a $1 / 2-$ Inch Penetrator and a $60 \mathrm{~kg}$ Load . . 
CHAPTER I

\author{
C . \\ INTRODUCTION AND HISTORICAL REVIEW
}

1. INTRODUCTION

Lead is one of the oldest metals known to man. This metal probably has more varied fields of application than any other. Some outstanding characteristics of lead include heavy weight, high density, softness, malleability, flexibility, low melting point, low strength, high resistance to corrosion under a wide variety of conditions, and its ability to shield nuclear radiation. Lead and its alloys have found use in ammunition, bearing metals, cable sheathing, foil, pipe, solder, battery plates, type metal and additives to paint and gasoline. The disadvantages of using pure lead in some engineering applications inçlude low fatigue resistance, extreme softness, low tensile strengths, and inability to have its mechanical properties enhanced by heat treatment.

Alloying is the only effective means available to enhance the properties of lead. A desirable solution to the problem; then, is to develop an alloy that is (1) rich in lead for nuclear properties, (2) corrosion resistant, and (3) capable of having its mechanical properties enhanced by heat treatment.

A number of binary and ternary systems have been investigated. Binary systems of general interest include lead-antimony, lead-arsenic, 
lead-cadmium, lead-calcium, lead-lithium, lead-silver, and lead-tin. Ternary systems of interest have included lead-antimony-arsenic, leadantimony-cadmi um, lead-antimony-silver, and lead-antimony-tin. Generally, the lead-calcium alloys have exhibited the best combination of fatigue resistance, tensile strength, and hardness without degradation of corrosion resistance and nuclear properties. Because of the enhanced combinations of mechanical properties of the lead-calcium alloys it is of special interest for use as cable sheathing, battery plates, and nuclear radiation shielding.

A method for welding lead-calcium alloys which maintains superior mechanical properties in the weld metal has not been developed. Therefore, when machined parts are required, the part must be machined from special castings. Molds for such castings can become very expensive when large or complex shaped parts are required. Also, long machining times are required because of excesslve sluck ieyuited for castings. It is, therefore, economlcaliy desirable to produce welded assumilies. The purpose of this study is (1) to determine the parameters necessary to produce a metallurgically sound weld with chemistry similar to the lead -0.06 weight percent calcium base metal and (2) to determine the effect of heat treatment on metallurgical and mechanical properties of the weld metal and hear-affected zurle in the lead-0.06 weight porcent calcium alloy, 


\section{HISTORICAL REVIEW -}

The Lead-Calcium System

The binary phase diagram for the lead-calcium system on the low calcium side indicates a eutectic reaction of 0.08 weight percent calcium as shown in figure 1. The solid solubility of calcium decreases from 0.07 weight percent at $326^{\circ} \mathrm{C}$ to approximately 0.01 weight percent at $0^{\circ} \mathrm{C}$. For an alloy containing less than 0.07 weight percent calcium a terminal solid solution exists at the eutectic temperature. Under equilibrium conditions, an alloy with less than 0.07 weight percent calcium could not contain any eutectic constituent. Generally, however, such an alloy will contain the eutectic constituent when solidified. This, of course, is caused by nonequilibrium solidification which causes the average composition of the solid phase to depart from that indicated by the solidus such that freezing is not complete before the eutectic temperature is reached. An alloy containing less than the maximum solid solubility may be brought to equilibrium after solidification by subjecting it to an extended exposure at a temperature between the solvus and solidus (a single phase region). The alloy will eventually become a single phase. During the heat treatment, homogenization occurs in two ways: (1) segregation of the primary phase $(\alpha)$ is: eliminated by interdiffusion of the components ( $\mathrm{Pb}$ and $\mathrm{Ca}$ ) and (2) the secondary phase $\left(\mathrm{Pb}_{3} \mathrm{Ca}\right)$ is dissolved in the primary phase. The rate at which these changes occur is dependent upon the temperature of the heat treatment and the time of exposure. By quickly cooling the 


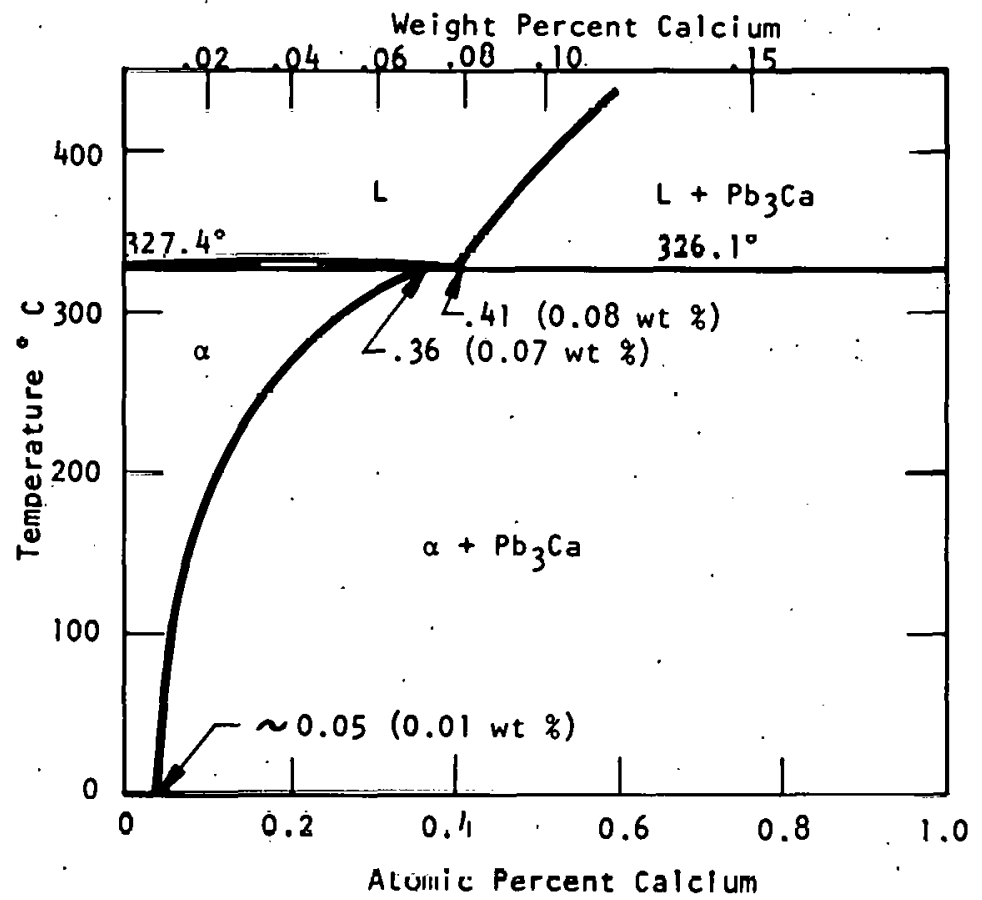

Figure 1. Lead-calcium binary phase diagram.' 
homogenized alloy to room temperature it is usually possible to retain the homogeneous single-phase condition.

When the homogenized terminal solid solution is cooled to a temperature below the solvus, the alloy becomes thermodynamically unstable and tends to reject the secondary $\left(\mathrm{Pb}_{3} \mathrm{Ca}\right)$ phase. This process is known as precipitation and is such that an increase in hardness and strength occurs concurrent with precipitation.

Heat Treatment of Lead-Calcium Alloys

A systematic search of Chemical Abstracts from 1907 to 1970 , inclusive, and Metallurgical Abstracts from 1934 to 1971, inclusive, was made to obtain references relating to lead-calcium alloys. A list of 135 references were obtained; only four articles were related to heat treating and five were related to welding of lead-calcium alloys. A planned computer search of Nuclear Science Abstracts (NSA) for the period 1963 to 1971, inclusive, was made on lead-calcium alloys. Nine references were listed; none were related to heat treating or welding. Schumacher and Bouton ${ }^{2}$ were the first to perform heat-treating evaluations on the lead-calcium alloy. Hardness data collected from samples water quenched from various temperatures $\left(200\right.$ to $\left.308^{\circ} \mathrm{C}\right)$ and allowed to age at room temperature showed that the lead-0.04 welght percent calcium solid solution first begins to precipitate $\mathrm{Pb}_{3} \mathrm{Ca}$ at a temperature between $228^{\circ} \mathrm{C}$ and $200^{\circ} \mathrm{C}$. Additional hardness data indicated that complete solution of the calcium ( 0.04 weight percent) did not take place until a temperature of about $265^{\circ} \mathrm{C}$ was reached. 
Tensile strength studies were reported to show definite age hardening in alloys containing as little as 0.01 weight percent calcium.

Dean and Ryjord 3 found that an ultimate tensile strength of 7000 psi was developed at an aging temperature of $100^{\circ} \mathrm{C}$ for 4 hours. The ultimate tensile strength, using the above aging treatment, was achieved with a calcium content ranging between 0.065 and 0.075 weight percent.

Schumacher and Phipps ${ }^{4}$ have reported that an witimate tensile strength of 8000 psi can be obtained with the alloy containing 0.1 weight percent calcium and aged at $20^{\circ} \mathrm{C}$ for $\mathrm{l}$ week and then aged at an elevated temperature of $100^{\circ} \mathrm{C}$ for 18 hours.

Townsend 5 investigated the nominal 0.07 weight percent calciumlead alloy. It was found that when the alloy contains as much as 0.05 weight percent calcium, it develops strengths in excess of 4000 psi. As the nominal calcium content drops to the 0.03 to 0.02 weight percent level, the tensile strength of the alloy drops rapidly.

Townsend further reports that the lead-calcium alloy was found to respond to solution heat treatment. Times from 2 to 16 hours were found adequate for treatment at $300^{\circ} \mathrm{C}$. When water quenched, the solution treated alloy hardened at room temperature in about 24 hours. Acceleraled aying al $100^{\circ} \mathrm{C}$ for 8 hours gave tensile strengths supcrior to those developed at room temperature. Preliminary room temperature aging. followed by accelerated aging was not demonstrated to be better than immediate accelerated aging. Hardness was found to give a regular but not a precise correlation with the tensile strength. 
Welding Lead-Calcium Alloys

Welding of lead-calcium alloys is made difficult by the great affinity of calcium for oxygen. Al'so; the specific gravity of calcium oxide is 3.35 compared to 11.4 for lead. Therefore, when a flame is used to melt the lead-calcium alloy, calcium oxide is formed and rises to the surface. Fusion of base metal and filler metal is prevented. because the calcium oxide adheres tightly to the surface and is difficult to break up. Also, when the alloy becomes calcium depleted, a reduction in the hardness and tensile strength can be expected as noted by Townsend. 5 Patents by Garten 6,7 indicate that parts to be welded must be heated to the melting point with a hydrogen-oxygen flame to burn the calcium out of the alloy. After the calcium has been oxidized and risen to surface, it can be removed by mechanical treatments exposing essentially pure lead which can be welded. The resulting weld metal was reported to be soft.

Hoehne and Schweinitz ${ }^{8}$ also indicate that the lead-calcium alloy is difficult to weld. No data was presented.

Scliuildalier and Phipps 4 stated, "The lead calcium alloys, in the composition range studied, can be fabricated by drawing, extruding, stamping, machining, welding, and burning." No data is presented to support these statements.

Abe, 9 in a Japanese patent, indicates that a lead welding rod containing 0.2 weight percent silver can be used to successfully weld lead-calcium alloys. The lead-silver alloy welding rod was reported to 
remove calcium oxide formed at the welding temperature and permits uniform welding by formation of intermetallic compounds or alloys by mutual diffusion of calcium and silver. There is no thermodynamic advantage' in using silver in the lead-calcium because the heat of formation of silver oxide is $-6.7 \mathrm{k}$ cal/mole compared to the much larger heat of formation of $-38.2 \mathrm{k}$ cal/mole for lead oxide. There is, however, a metallurgical advantage in using the lead-silver alloy filler metal because the silver replaces the oxidized calcium and acts as a precipitation hardening agent. 
CHAPTER II

\section{EXPERIMENTAL PROCEDURE}

\section{MATERIAL PREPARATION}

The material used in this investigation was prepared from a premium grade of corroding lead. The calcium was added as a 1 weight percent calcium master alloy. Alloying was achieved by induction heating pure molten lead to $520^{\circ} \mathrm{C}$ before addition of the master alloy. A stainless steel rod was used to stir the melt to assure complete mixing of the melt. The metal was then poured into the mold after the temperature was reduced to $450^{\circ} \mathrm{C}$. The mold was water-spiray quenched immediately after pouring. After the ingot was removed from the mold, it was cold rolled to 1/4-inch-thick plate. The gross chemical and impurity analysis of the alloy used is reported in Table f

The plate was cut into samples which were 8 inches long, 2 inches wide and $1 / 4$ inch thick. No effort was made to preserve the identity of the individual samples until after welding. This permitted samples to be selected for welding on a purely random basis with respect to any composition variation that might be present in the plate.

Strips $1 / 4$ inch thick square were sheared from the parent plate and swaged to 0.100 inch diameter for welding wire. Heat treatments were not used between swaging operations. Just prior to welding, the wire was chemically cleaned in a 50 volume percent nitric acid-water solution and then swaged to 0.094 inch diameter. 
TABLE 1

GROSS CHEMICAL AND IMPURITY ANALYSIS OF THE NOMINAL

LEAD-0.06 WEIGHT PERCENT CALCIUM

USED IN THIS INVESTIGATION ${ }^{a}$

\begin{tabular}{lc}
\hline \hline Lead & $99.92 \%$ \\
Calcium & $0.059 \%$ \\
Aluminum & 15 \\
Antimony & $<6$ \\
Arsenic & $<20$ \\
Bismuth & 5 \\
Cadmium & $<6$ \\
Chromium & $<1$ \\
Copper & $<1$ \\
Iron & $<1$ \\
Lithium & $<1$ \\
Magnesium & 10 \\
Manganese & $<1$ \\
Nickel & $<4$ \\
Phośphònusis & $<100$ \\
Silver & 20 \\
Sodium & 1 \\
Tin & 2 \\
\hline \hline
\end{tabular}

a 11 values in ppm, except where noted. 


\section{WELDING PROCEDURE}

A welding procedure was developed for welding $1 / 4-i n c h$ thick. plate using the gas tungsten-arc welding process with filler wire addition. The welding procedure was developed using a V-groove joint with a 60-degree included angle, no root face and no root gap. The joint geometry is shown in Figure 2 .

The welding specimens were held in position with an aluminum fixture. A 1-inch-square copper backing strip with a 1/8-inch wide, 1/16-inch deep groove was located below the weld joint. Copper chill bars, $1 / 4$ inch thick, were placed on the weld side of the welding specimens $5 / 16$ inch from the center line of the weld joint. The copper chill bars and welding specimens were held in place with an aluminum hold-down bar. Copper start and run-off tabs were positioned at the ends of the weld joint. Figure 3 is an illustration of the fixture. An illustration of the welding coupons in the welding fixture is shown in Figure 4.

A templet was used to uniformly align the welding specimens, copper chill bars and aluminum hold-down bars. Figure 5 is an illustration of the templet.

Immediately before welding, the welding specimens were mechanically cleaned by scraping the surface to be welded. The tool used to scrape the surface is illustrated in Figure 6.

The welding parameters for a single pass weld, shown in Table 11 , were developed using an Airco 600-amp, single-phase, $A C / D C$ welding power supply. A voltage control head was used to maintain a constant arc 


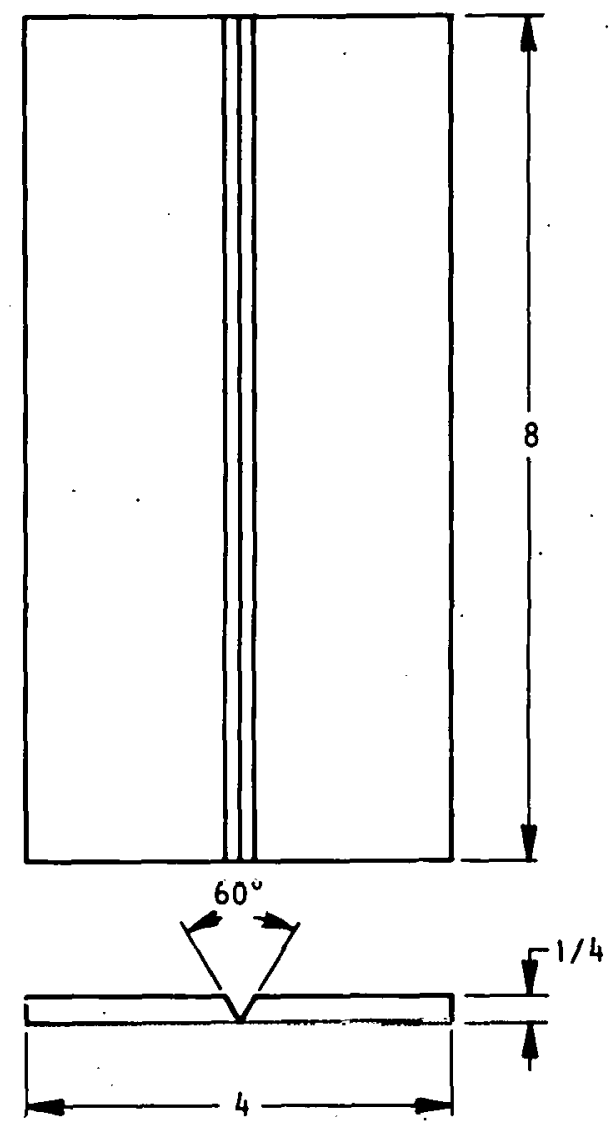

Figure 2. Joint geometry used in this investigation. 


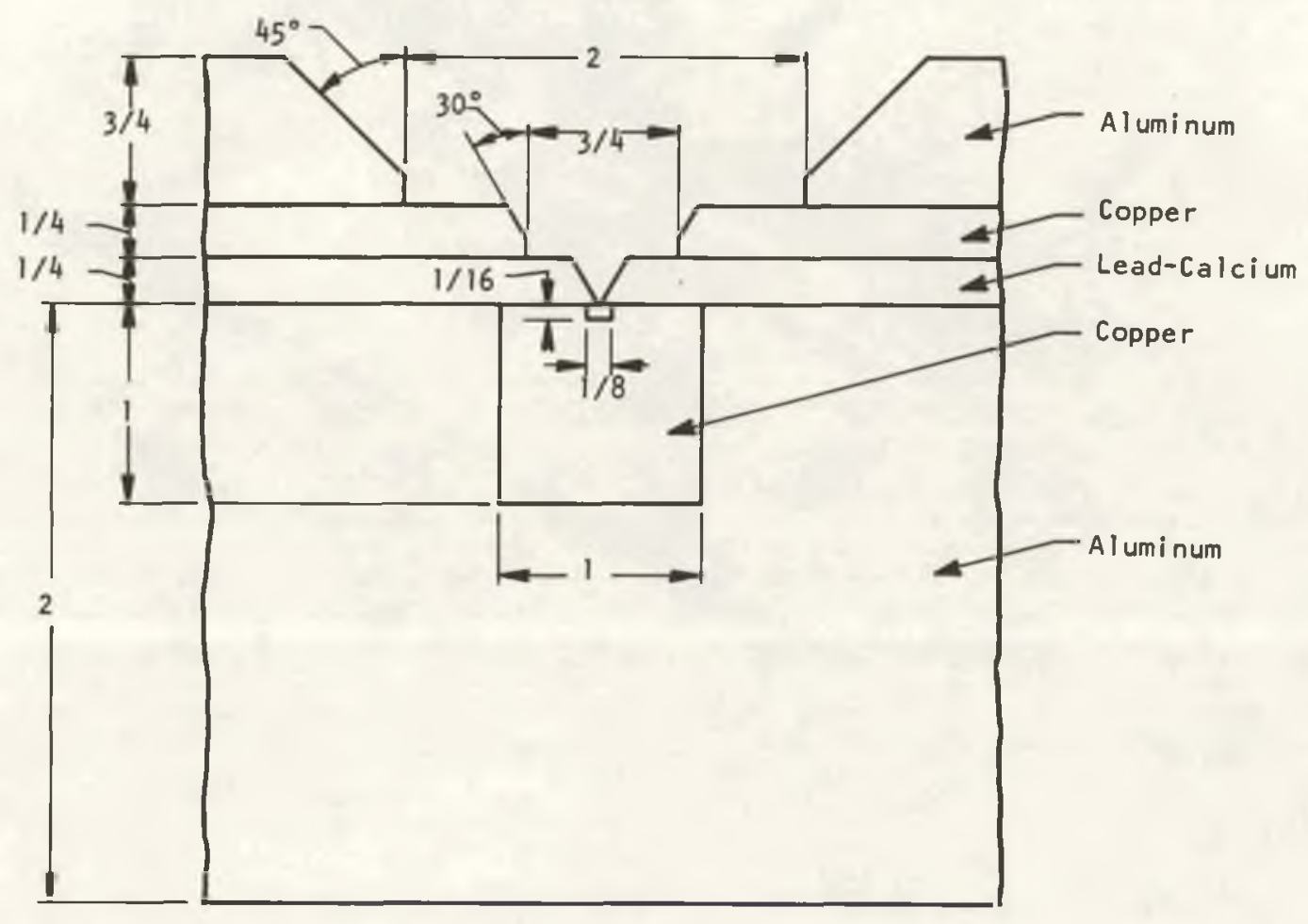

Figure 3. Welding fixture used in this investigation. 


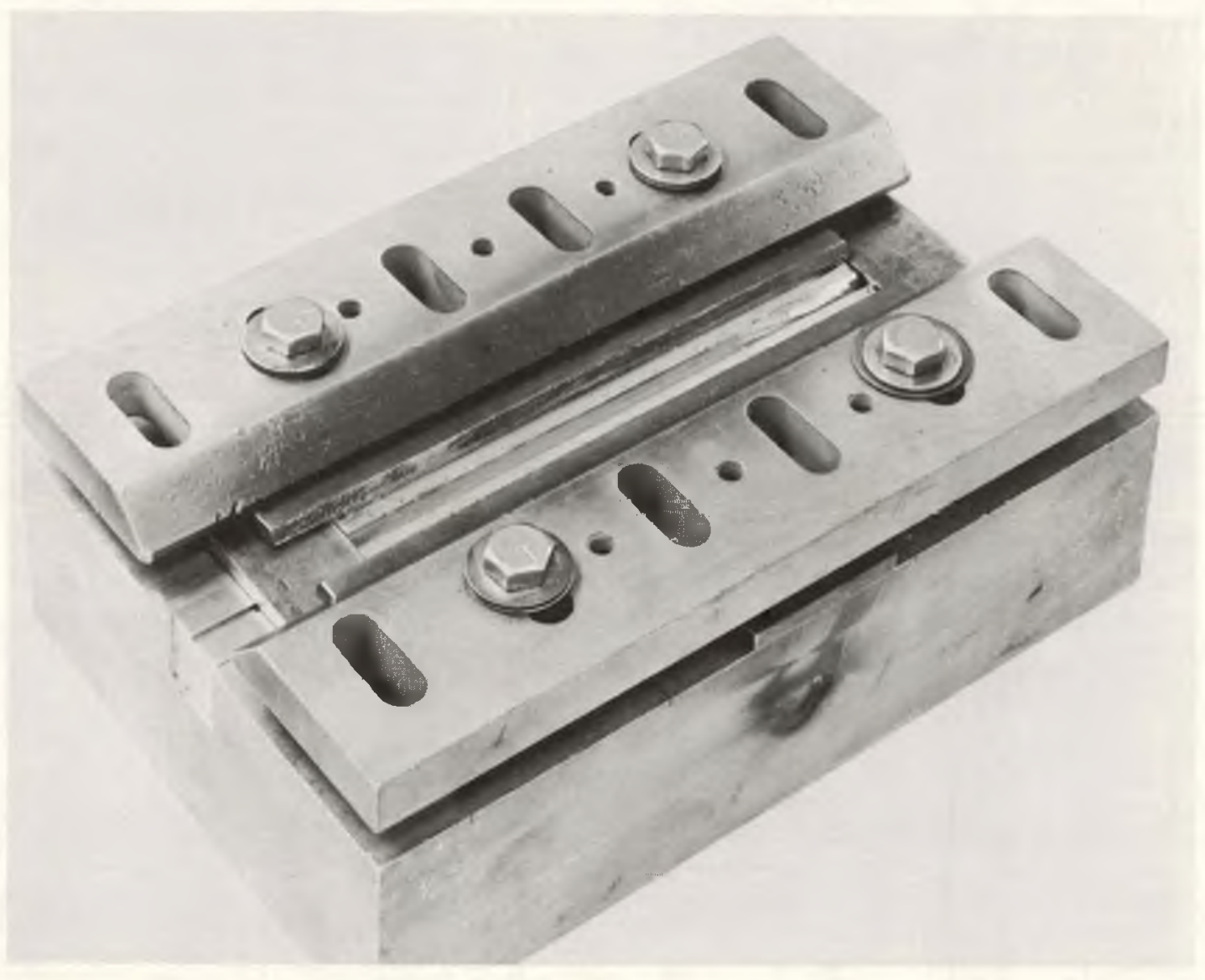

Figure 4. Lead-calcium welding specimens in the welding fixture. 


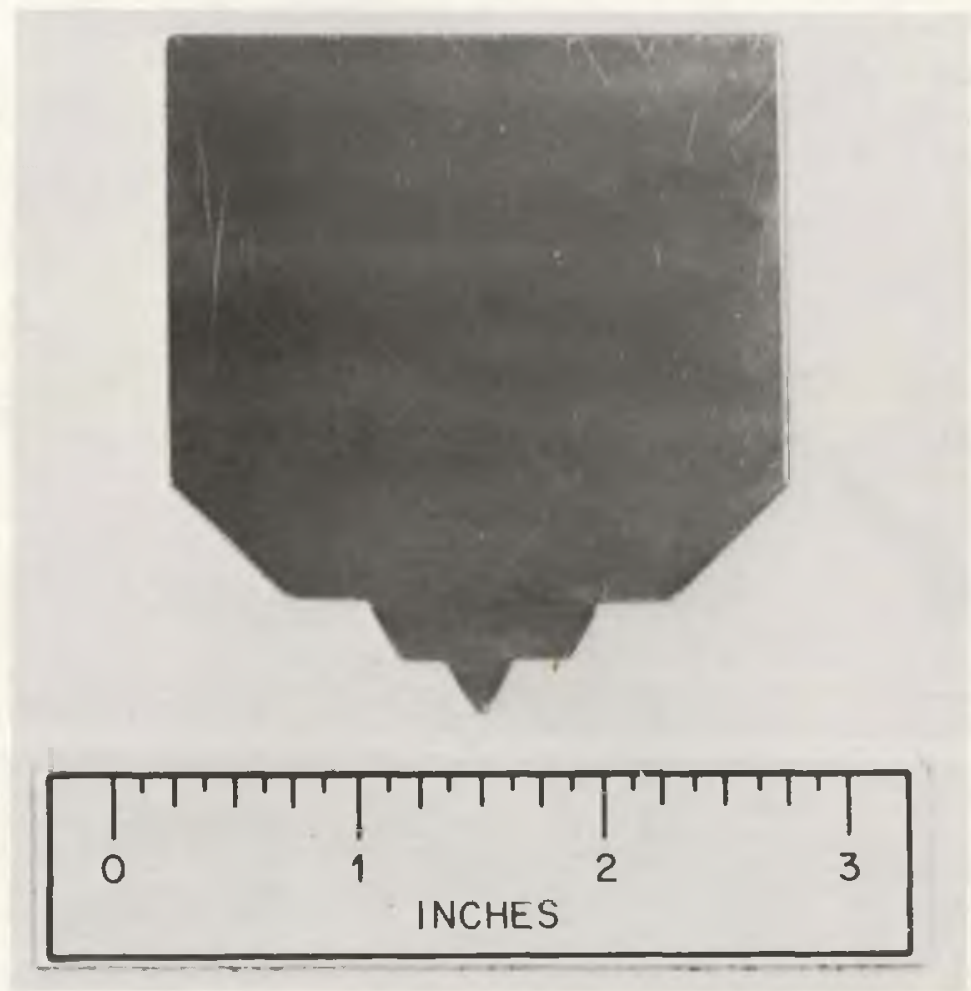

Figure 5. The templet used to align the welding coupons, copper chill bars and aluminum hold-down bar. 


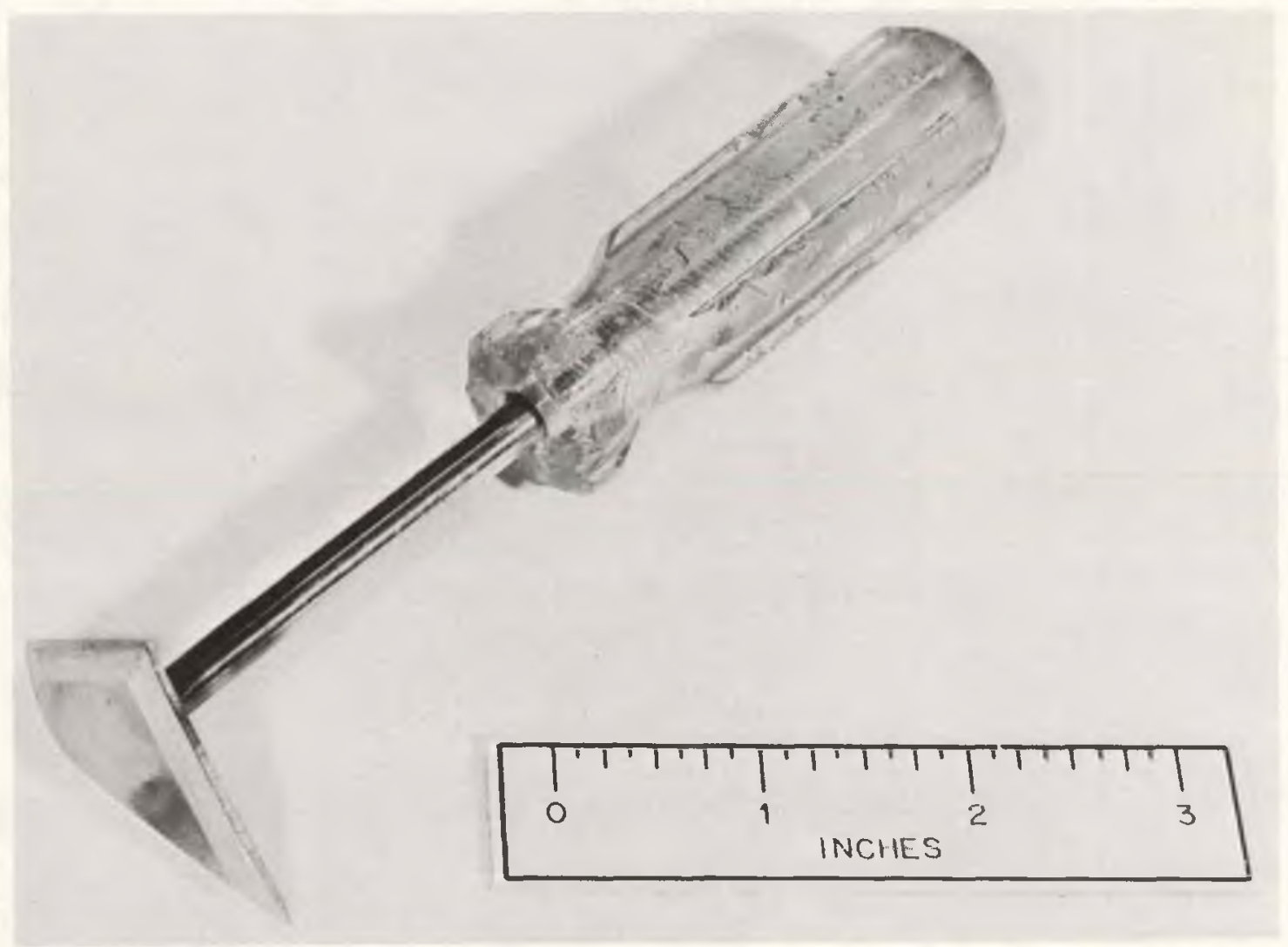

Figure 6. Scraping tool used to clean the welding coupon surface prior to welding. 
TABLE. I I

PARAMETERS USED TO WELD LEAD-CALCIUM PLATE

\begin{tabular}{ll}
\hline \hline Process & Gas Tungsten-Arc \\
Current (mode) & Alternating Current \\
Current (amp) & 270 \\
Travel Speed (ipm) & 6,6 \\
Type of Arc Starting Device & High Frequency \\
Shielding Gas & Argon \\
Flow Rate (cfh) & 20 \\
Pre-flow Time (seconds) & 5 \\
Torch & 500 amp, Water Cooled \\
Electrode Type & $2 \%$ Thoriated Tungsten \\
Electrode Diameter & $1 / 8$ inch \\
Arc Voltage (volts) & 8 \\
Wire Feed Rate (ipm) & 56 \\
Work Slope (in/in) & +0.02 \\
\hline \hline
\end{tabular}


voltage. Wire was automatically fed into the arc at a constant feed rate with a wire feeder. A welding manipulator was used to move the welding torch at a constant travel speed.

\section{CHEMICAL ANALYSIS}

Calcium analysis of the lead-calcium alloy was nbtained by. the atomlc absorption method. Base metal and weld metal sampling was. accomplished by drilling using a $1 / 2-i n c h$ drill and collecting the chips. The wire sampling was accomplished by cutting sections from the beginning and end of each filler wire. The accuracy of determinations at 95 percent confidence limits was reported to be \pm 5 percent.

\section{HEAT TREATMENT AND AGING}

The specimens used in this study were heat treated in a boxtype resistance-heated furnace. Specimens used to obtain hardness data were heat troatod and aged under the following scliedules:

1. Solution heat treated at $300^{\circ} \mathrm{C}$ for $\mathrm{I}$ to 24 hours, water quenched and room temperature aged for up to two weeks.

2. Solution heat treated at $300^{\circ} \mathrm{C}$ for two hours, water quenched and aged at $100^{\circ} \mathrm{C}$ for up to 96 hours. followed by a two-week room temperature age.

3. As-deposited weld metal room temperature aged for up to two weeks. 
Specimens used for tensile strength evaluation were heat treated and aged under the following schedules:

1. Solution heat treated for two hours at $300^{\circ} \mathrm{C}$, water quenched and room temperature aged for up to two weeks.

2. Solution heat treated for two hours at $300^{\circ} \mathrm{C}$, water quenched and aged at $100^{\circ} \mathrm{C}$ for up to 48 hours.

3. As-deposited weld metal room temperature aged for two weeks.

\section{HARDNESS AND TENSILE STRENGTH MEASUREMENTS}

\section{Macirohardness}

The hardness numbers used in this work were obtained using a Rockwell hardness tester with a 1/2-inch-diameter steel ball for a penetrator and a 60-kilogram load applied for 45 seconds. The depth of penetration as indicated by the Rockwell dial was used as a measure of the impression diameter. See Appendix A for a discussion of the conversion of Rockwell numbers to Brinell Hardness numbers.

\section{Microhardness}

Hardness values were determined on several solution heat treated and aged samples and samples in the as-welded condition: Diamond pyramid hardness values were obtained using a 100-gram load on a Tukon microhardness tester. Readings were taken by traversing from the base metal to the weld metal on a specimen section transverse to the weld. 
Tensile Strength

Tensile strength values were obtained on a Tinius olsen tensile testing machine with a strain rate of 0.25 inch per inch per minute. Flat tensile specimens were used with a $1 / 4$-inch-square cross section. Elongation was determined over a l-inch gage length. Figure 7 is a sketch of the tensile specimen used in this evaluation.

Longitudinal weld metal specimens contained all weld metal while transverse.weld specimens contained weld metal, heat-affected zone and base metal.

\section{METALLOGRAPHY}

Longitudinal and transverse cross sections of welded specimens were examined metallographically. The specimens were mounted in epoxy, ground through 600-grit silicon carbide paper impregnated with parafin and kerosene as a lubricant. Polishing and etching was accomplished by Using a solution containing 60 volume percent acetic acid, 20 volume percent hydrogen peroxide and 20 volume percent ethyl alcohol. A swab etch method was used. Etching times of approximately 10 seconds were required:

\section{Electron Microprobe Analysis}

Transverse cross sections of welded specimens were analyzed with the electron-microprobe. The areas of interest included the weld metal, base metal and heat-affected zone. Attempts were made to determine the location of lead-calcium precipitates and any segregation of the precipitates. 


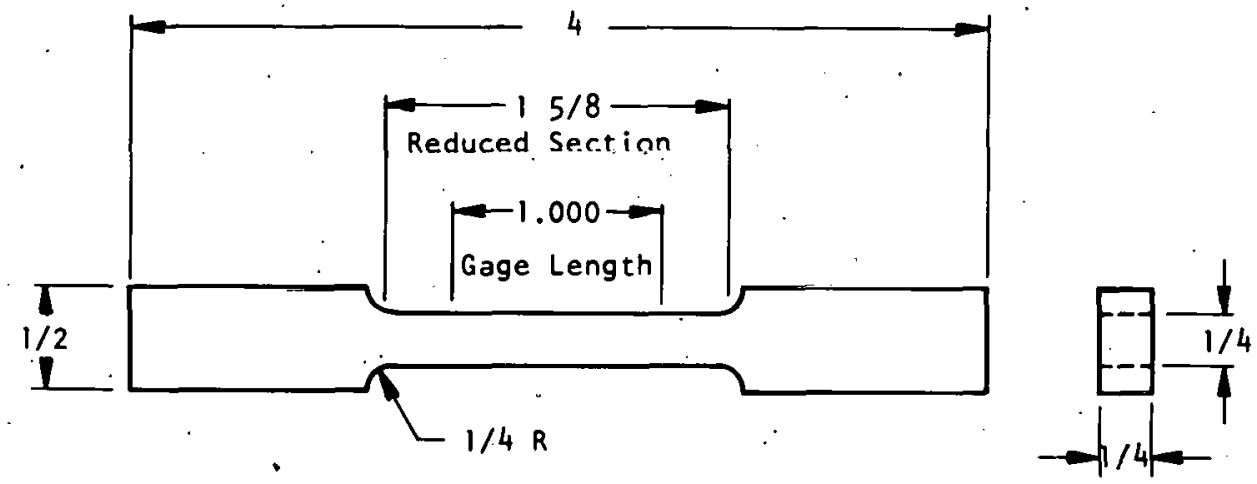

Figure 7. Tensile specimen used in this evaluation. 
An electron microprobe $X-$ ray analyzer, Model 4005 , manufactured by Materials Analysis Corporation, was utilized for this work. A takeoff angle of $381 / 2$ degrees and 25 kilovolts were utilized in performing the analysis. Values were corrected for the background radiation and the beam current fluctuations. Calcium $K_{\alpha}$ radiation was used to determine the presence of calcium by $l i n e$ scans, point analysis, and $X$-ray images. The diameter of the $X$-ray beam was 1.0 micron.

\section{Scanning Electron Microscopy}

Several tensile coupons did not fail in a characteristic ductile knife edge manner but appeared to contain porosity in the fractured surface when observed with the unaided eye. Scanning electron microscopy was utilized to aid in the determination of the apparent non ductile. fracture. Fractographs were obtained on several samples with a lype JSM2 scanning electron microscope manufactured by Japan Optics Laboratory Co., Ltd. Only the secondary electron scatter mode was utilized at an operating voltage of 25 kilovolts.

\section{SAFETY}

A ventilation system was required during welding to remove the lead vapors formed during wclding. A six-inch-diametcr exhaust vent with an air flow velocity of $4000 \mathrm{fpm}$ was positioned 16 inches from the arc. The air flow velocity at the arc was approximately $40 \mathrm{fpm}$. A photograph of the lead vapor flow pattern is shown i.n Figure 8 . Also, during welding, a respirator was worn by the welder to prevent accidental 


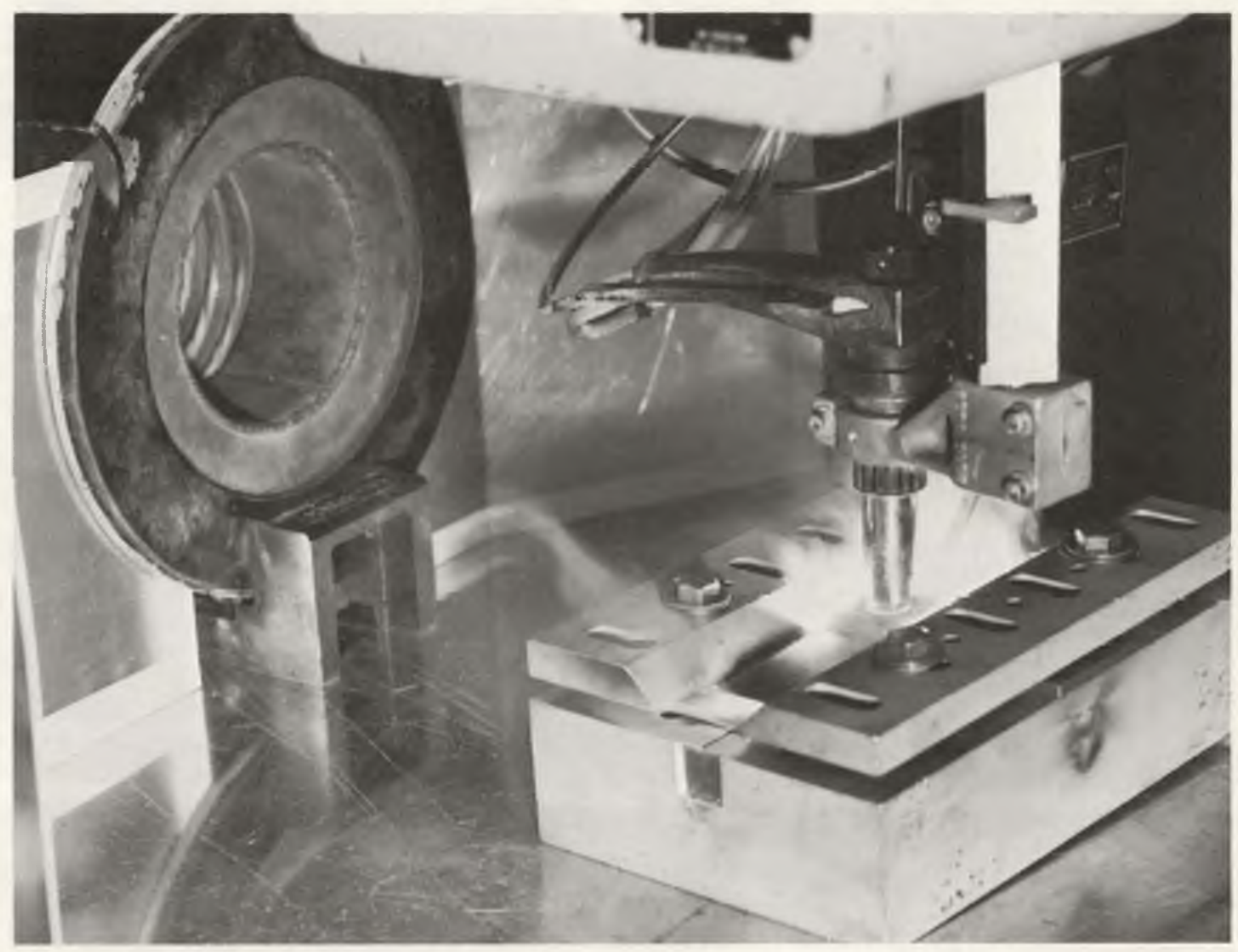

Figure 8. Lead vapor flow pattern during welding. 
inhalation of lead vapors. After welding of each sample, the fixture and sample were wire brushed near the exhaust vent to prevent the deposited lead vapors from becoming airborne during handling. Care was taken by the welder to wash prior to eating or drinking after handing samples covered with lead vapors.

A chemical analysis of deposited vapors indicated approximately 0.3 percent calcium with the remainder being lead. 
CHAPTER \|\|

\section{RESULTS AND DISCUSSION}

\section{WELDING THE LEAD-CALCIUM ALLOY}

A number of welding processes including oxy-acetylene, gas tungsten-arc, electron-beam and plasma-arc were evaluated to determine if these processes could produce a weld in the lead-calcium alloy without significant calcium losses. Further evaluations were carried out to ensure that a weld with no objectionable defects and adequate mechanical properties could also be obtained with these candidate processes. One-half-inch-thick lead-nominal 0.06 weight percent calcium plates were obtained for welding. The plates were chemically cleaned in a boiling 50 percent nitric, 50 percent water solution immediately before welding. Selected portions of the plates were fused with the above mentioned welding processes. Chemical analysis was then obtained from the fused areas. The results of the chemical analysis indicated that calcium was not being lost during melting and solidification with any of the candidate welding processes. Thus, the beneficial metallurgical effects of calcium can be retained during welding and the weld fusion zone will be susceptible to subsequent heat treatments.

In order to determine if the lead-calcium alloy could be fusion welded without defects, additional $1 / 2$-inch plates were prepared with a V-groove joint. Strips were sheared from $1 / 4-i n c h$ plate to provide filler metal for the welds. The calcium content of the sheared strips 
was similar to that of the base metal. The base plates and filler metal were chemically cleaned in.the manner described above immediately prior to welding with the candidate processes save for the electron-beam welding process.

The oxy-acetylene gas welding process was evaluated utilizing an oxidizing, carburizing and neutral flame. With each of the three flames used, a thick oxide layer quickly formed on the surface of the molten weld metal. This oxide prevented fusion by inhibiting the melting and mixing of the material from both sides of the joint. For this reason the further evaluation of the oxy-acetylene welding process was discontinued.

The plasma-arc welding process was evaluated and during welding an oxide film, similar to that which formed during oxy-acetylene welding, also occurred: The same lack of fusion resulted from this oxide. The oxide film which tormed during plasma welding did not appear to be as thick as that produced by gas welding but still effectively inhibited proper fusion. Likewise, this process was eliminated from further evaluation.

The electron-heam welding process, oven. though it did not cause oxidation of the alloy, was not evaluated for fus wo ting bacusse of the difficulty of adding filler metal in the closed chamber. A welding process which permits filler wire additions is highly desirable in most applications. Thus, the electron-beam process was eliminated from any further consideration. 
The final welding process evaluated was gas tungsten-arc, welding. Direct current reverse polarity, direct current straight polarity and alternating current were used in the evaluation.

Direct current straight polarity permitted a thin oxide layer to form which inhibited proper fusion. The oxide layer formed was very similar to the oxide layer formed with the plasma-arc process. Direct current reverse polarity caused the arc to be very erratic and unstable. The weld metal, however, was free of oxide films during welding and adequate fusion resulted. The erratic arc produced a weld with a rough uneven surface. Welding with an alternating current caused the thin oxide layer to break up which permitted fusion and resulted in a smooth weld bead.

Since the alternating current gas tungsten-arc process produced the best weld configuration with no interference. from the thin oxide film, it was decided to continue further evaluations using this process alone to determine whether filler metal additions and continuous fusion welding influences calcium losses. Additional chemical analysis were obtained from the weld plates. The analysis indicated that no calcium losses were occurring. Thus, the gas tungsten-arc alternating current process appeared to be adequately suited to welding the lead-calcium alloys.

In order to simplify the metallurgical analysis of the weld metal and heat-affected zone a single päss weld was deemed desirable. In a single pass weld no complicating overlapping fusion passes are ' encountered and the base material is subjected to only one thermal 
excursion. Welding parameter studies showed that single pass welds could not be made in 1/2-inch-thick plate. Further work showed that suitable single pass welds could be made in $1 / 4-i n c h-t h i c k$ plate. Therefore, the remaining metallurgical and mechanical studies were carried out using 1/4-inch-thick plate. with a single pass weld sequence. In order to reduce to a minimum the amount of oxide on the metal surfaces prlor to welding, cleaning studies were performed. The cleaning studies indicated that a surface mechanically cleancd by scraping produced welds equal in quality to welds made on surfaces chemically cleaned in the manner described above. Also, mechanically cleaning was performed at the welding station which permitted the samples to be welded immediately after cleaning. Therefore, the remaining welding studies were carried out using mechanically cleaned surfaces. The filler wire, which did not lend itself readily to mechanical cleaning, was chemically cleaned.

Chemical analysis of the filler wire and base metal plates used for each weld were performed. The resulting. fusion zone on each of the welded assemblies was alsn analyzed. The rosults of thesc chemical analysis are presented in Table 111 . The calcium content in the base metal, all of which came from a single heat, ranged between 0.042 and 0.077 weight percent with an average of 0.058 weight percent. The filler metal, which was from the same heat as the base metal, ranged in calcium content from 0.046 to 0.066 weight percent with an average of 0.055 weight percent. The weld metal calcium content ranged between 
TABLE II

CALCIUM CONTENT OF WELD METAL COUPONS USED FOR HARDNESS AND TENSILE STRENGTH EVALUATION, WEIGHT PERCENT

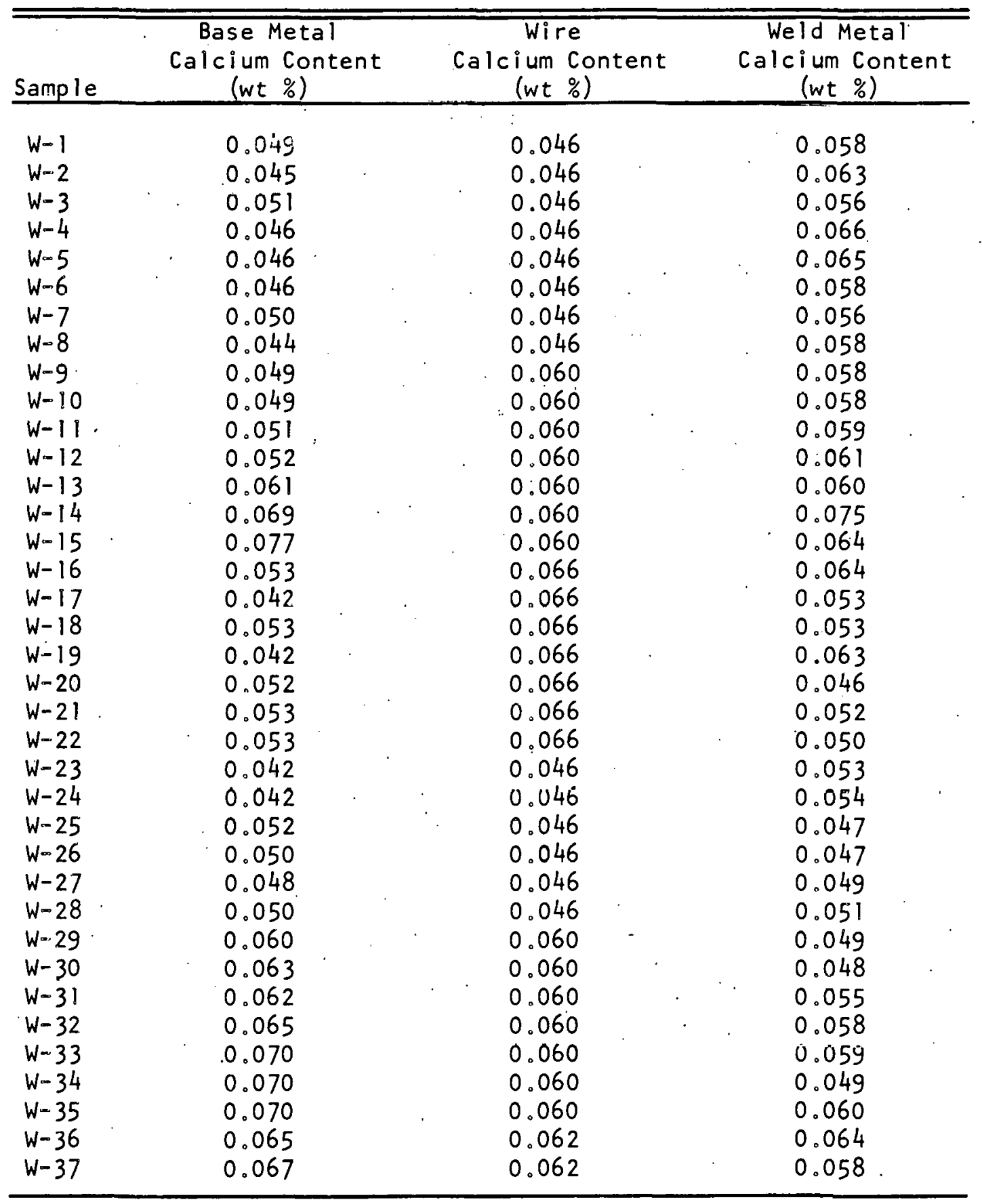


TABLE III (Continued)

\begin{tabular}{lccc}
\hline Sample & $\begin{array}{c}\text { Base Metal } \\
\text { Calcium Content } \\
\text { (wt \%) }\end{array}$ & $\begin{array}{c}\text { Wire } \\
\text { Calcium Content } \\
\text { (wt \%) }\end{array}$ & $\begin{array}{c}\text { Weld Metal } \\
\text { Calcium Content } \\
\text { (wt \%) }\end{array}$ \\
\hline W-38 & 0.064 & 0.062 & 0.065 \\
$W-39$ & 0.063 & 0.062 & 0.067 \\
$W-40$ & 0.062 & 0.062 & 0.064 \\
$W-41$ & 0.064 & 0.062 & 0.065 \\
$W-42$ & 0.064 & 0.060 & 0.062 \\
$W-43$ & 0.060 & 0.060 & 0.063 \\
$W-44$ & 0.059 & 0.060 & 0.057 \\
$W-45$ & 0.058 & 0.060 & 0.064 \\
$W-46$ & 0.057 & 0.060 & 0.060 \\
$W-47$ & 0.057 & 0.060 & 0.067 \\
$W-48$ & 0.061 & 0.062 & 0.061 \\
$W-49$ & 0.063 & 0.062 & 0.063 \\
$W-50$ & 0.064 & 0.062 & 0.062 \\
$W-51$ & 0.060 & 0.062 & 0.061 \\
$W-52$ & 0.062 & 0.062 & 0.060 \\
$W-53$ & 0.062 & 0.062 & 0.062 \\
$W-54$ & 0.062 & 0.062 & 0.061 \\
\hline \hline
\end{tabular}


0.046 and 0.075 weight percent with an average of 0.059 weight percent. All of these average values are in a range which can be considered to fall within the limits of experimental error. Thus, these data again in-

dicate that the lead-calcium alloy can be welded without calcium losses.

\section{MECHANICAL PROPERTIES}

The initial phase of the mechanical property evaluation was the characterization of the properties of the base metal attainable by heat treatment. The properties used for primary evaluation were hardness and tensile strength. Base metal characterization served as a bench mark for comparison and evaluation. of the heat-affected zone and weld fusion zone properties. The results of the chemical analysis of the base metal samples are reported in Appendix $B$.

\section{Hardness}

In order to determine the minimum time to achieve essentially complete solid solubility of calcium in lead, base metal samples in the completely overaged condition were used. To obtain base metal in the overaged condition, samples were heated to $300^{\circ} \mathrm{C}$ for 48 hours followed by a furnace cool to achieve an "equilibrium" cooling rate. Room temperature was reached in approximately 14 hours. The hardness was checked on all of the samples after the furnace cool and averaged 6.9 BHN with a range of 6.0 to $7.4 \mathrm{BHN}$. These data compare with the hardness of cast and cold rolled base metal which averaged 6.4 BHN with a range of 5.1 to $6.4 \mathrm{BHN}$. No increase in hardness of the overaged samples was noted over a perlod of several months. 
The overaged samples were heated to $300^{\circ} \mathrm{C}$ for periods of 1 to 24 hours followed by a water quench and room temperature age. The hardness was measured immediately after the water quench and then monitored at various time intervals to determine if the samples had responded to precipitation hardening: A similar response to precipitation hardening would indicate that the samples had achieved a similar solid solubility level of calcium.in lead during the solution treatment. The results of all hardness studies are reported in Appendix C. A plot of the data obtained for one-hour and 24-hour solution times is shown in Figure 9. The data for time intervals between these limits are not shown since they were virtually identical to the 1 and 24-hour data. These data indicate that solution heat treatment times of 1 and 24 hours will produce identical hardness after aging at room temperature. These data also indicate that the hardness can be increased approximately two fold over the completely overaged material from $6.9 \mathrm{BHN}$ to $12.5 \mathrm{BHN}$ after a room temperature age of one week and three fold over the solution heat treated and as-quenched hardness (from $4.5 \mathrm{BHN}$ to $12.5 \mathrm{BHN}$ )。

Based on these data and the fact that one hour at the solution heat treatment temperature may be a minimum time, a solution heat treatment time of two hours was chosen for all further base metal samples. In order to determinc the affect of elevaled lumperature aging, additional overaged base metal samples were solution heat treated at $300^{\circ} \mathrm{C}$ for two hours, water quenched and immediately aged at $100^{\circ} \mathrm{C}$ in boiling water. Aging times of 15 minutes, 1, 12, 24, 48 and 96 hours were used. Hardness data was obtained on each sample immediately following the time interval at the $100^{\circ} \mathrm{C}$ aging temperature. Following the 


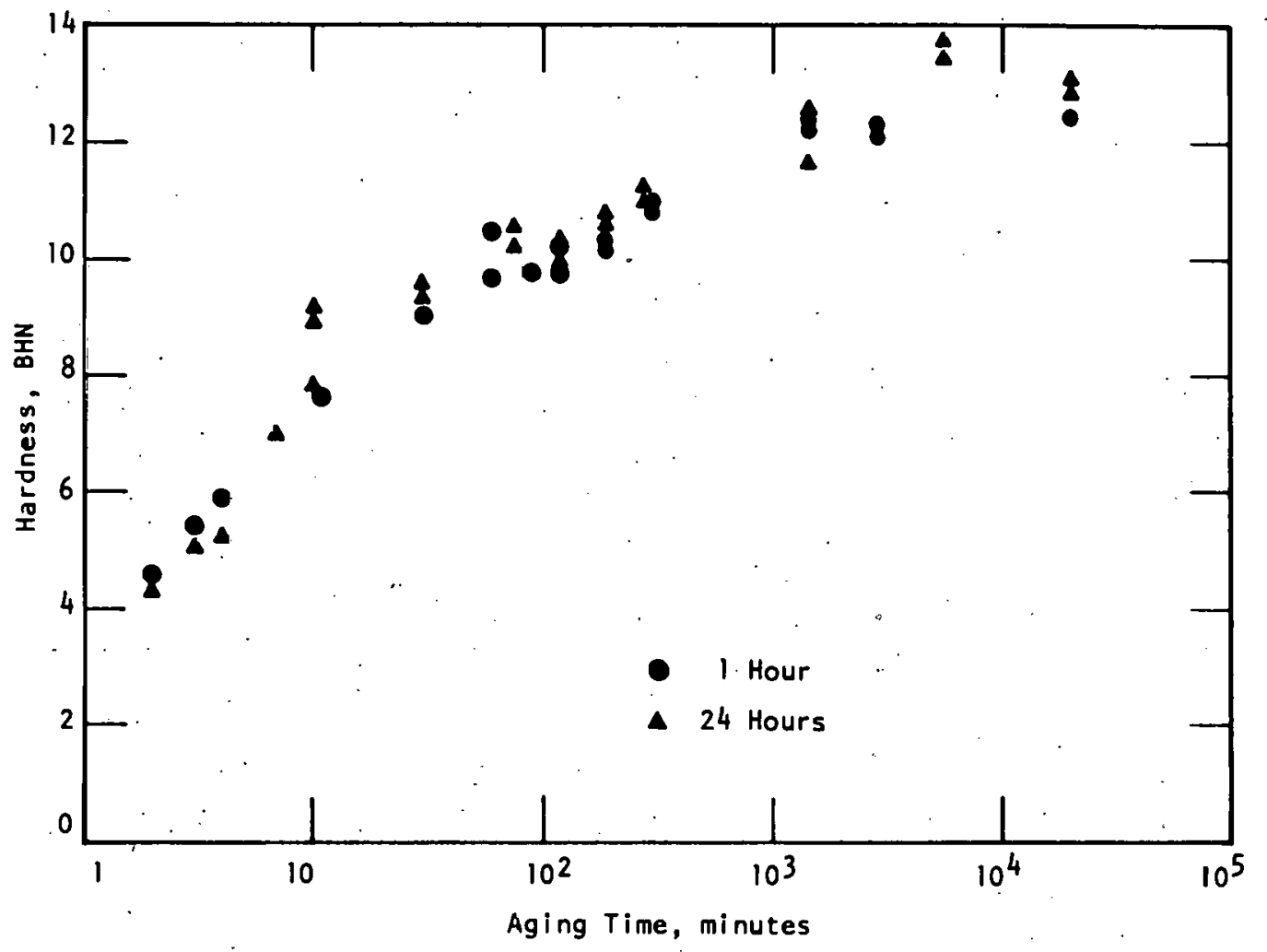

Figure 9. Hardness versus aging time for base metal samples solution heat treated at $300^{\circ} \mathrm{C}$ for different times, water quenched, and room temperature, aged. 
elevated temperature age, the samples were allowed to remain at room. temperature and.hardness data was obtained at various time intervals for a two-week period. The hardness did.not change during the room temperature age following completion of the elevated temperature age for any of the samples. A plot of the data obtained for this study is presented in Figure 10. The apparent step in the data between thc 12 and 24-hour aging time is not considered significant for two reasons. First, the hardness values are different by only approximately 2 .BHN which is not a large difference when compared to the variation of hardness at each aging time. Seçond, the same trend dnes not appear in the weld metal hardness data which will be presented later. These data also indicate that an aging time of 24 hours is adequate for an elevated temperature age which is a much shorter time than the one week required for the room temperature age. A maximum haroness of 13.0 BHN achieved for the $100^{\circ} \mathrm{C}$ age comfares favorably with the 12.5 BHN achieved with Llis roun temperazure age. Uverdying alld not appear to occur at $100^{\circ} \mathrm{C}$ with aging times up to 96 hours.

In order to determine if weld metal would respond to solution heat treatment in a manner similar to the hase metal, weld motal samplos were solution heat treated at $300^{\circ} \mathrm{C}$ for times of 1 to 24 hours and water quenched. Immediately following the water quench, the hardness was measured and then monitored at various time intervals for a twoweek period. A plot of the hardness versus aging time is presented in Figure 11. These data indicate that solution heat treatment times of 1 and 24 hours produce identical hardness levels. The data for times 


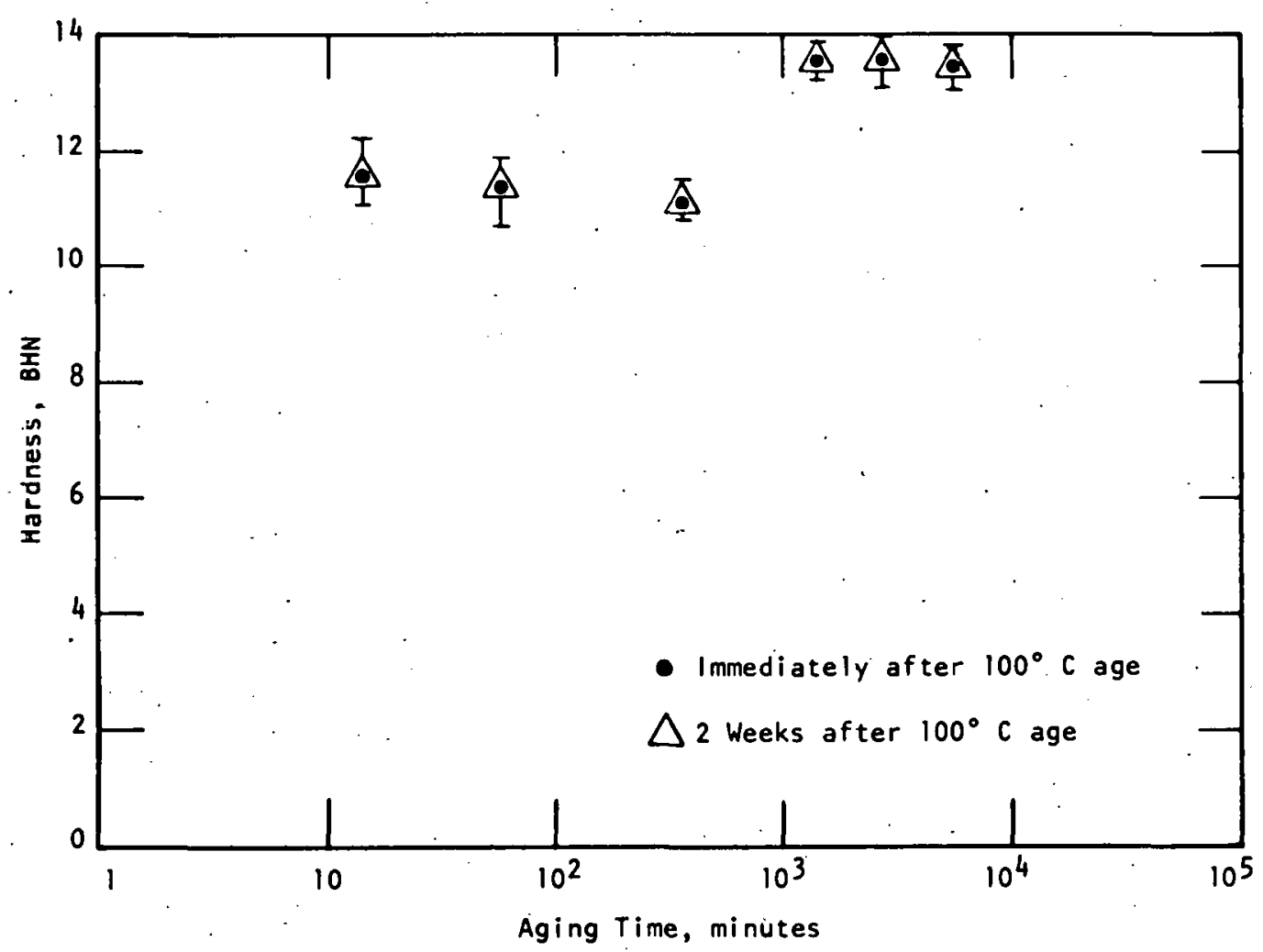

Figure 10. Hardness versus aging time at the elevated aging temperature for base metal samples solution heat treated at $300^{\circ} \mathrm{C}$ for two hours, water quenched, and aged at $100^{\circ} \mathrm{C}$. 


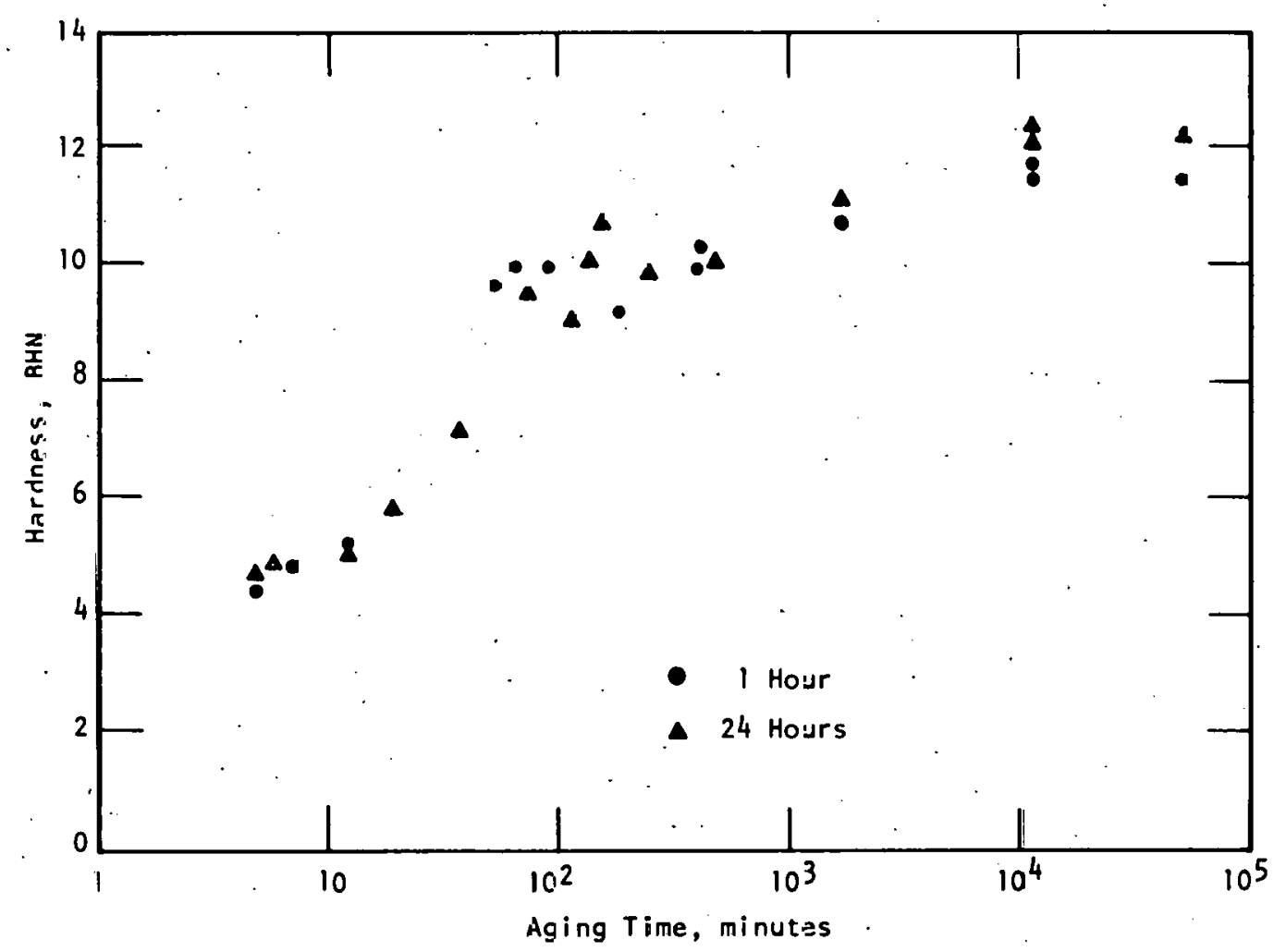

Figure 11. Hardness versus aging time for weld metal samples solution heat treated at $300^{\circ} \mathrm{C}$ for different times, wa ter quenched, and room temperature aged. 
between 1 and 24 hours are not shown but were virtually identical to the 1 and 24-hour times. Although one hour appears to be adequate to achieve sufficient solid solubility of calcium in. lead, a two-hour solution heat treatment time, as with the base metal, was selected for solution heat treating all further weld metal samples. The maximum weld metal hardness reached a nominal value of 12.0 BHN in one week which compares to the maximum base metal hardness of $12.5 \mathrm{BHN}$ also after aging one week. The hardness values for the weld metal at each time interval were approximately $I$ BHN lower than that indicated for base metal and is considered insignificant because of the data spread at each time interval.

It is concluded that weld metal responds to solution heat treatment in much the same manner as the base metal and the hardness reached at similar aging times is essentially identical to that achieved in the base metal.

To determine if weld metal would respond in a manner similar to the base metal during an elevated temperature age additional weld metal samples were solution heat treated at $300^{\circ} \mathrm{C}$ tor two hours, water quenched and immediately aged at $100^{\circ} \mathrm{C}$ for times including $1 / 2,1,4$ and 48 hours. Hardness data.was obtained on each sample immediately following the $100^{\circ} \mathrm{C}$ age. Following the elevated temperature age, the samples were maintained at room temperature and hardness data was obtained at various time intervals for a two-week period. As with the base metal, the hardness did not change during the room temperature age following completion of the elevated temperature age. A plot of the 
hardness data is presented in figure 12. An aging time of 24 hours, the same as for the base metal, was required to achieve a maximum hardness of 12.0 BHN. Again, the weld metal specimens had hardness values slightly lower than the base metal by approximately I BHN.

To determine if weld metal allowed to room temperature age after welding would respond in a manner similar to solution heac ereated and room temperature aged weld metal, additional weld metal samples were prepared. Hardness data was obtained immediately after welding and subsequently mibl cored a various time intervals for a two-week period. A plot of the data obtained for this study is shown in figure 13. The hardness increased during aging to a nominal value of $12.0 \mathrm{BHN}$ after an aging time of one week. The maximum hardness is essentially the same as the base metal hardness of $12.5 \mathrm{BHN}$ and weld metal hardness of 12.0 BHN achieved by solution heat treating at $300^{\circ} \mathrm{C}$ for two hours, water quenching and room temperature aging for one week. If the cooling race of the sollditied weld metal was too slow, the hardness would be expected to be near the hardness of $6.9 \mathrm{BHN}$ obtained with furnace cooled base metal samples. Apparently, the cooling rate is great enough to sufficiently quench the solidified weld metal to cause supersaturation and subsequent age hardening. Thus, weld metal would not be expected to require a solution heat treatment and water quench subsequent to welding to achieve a hardness similar to that of solution heat treated and aged weld metal or bașe metal. 


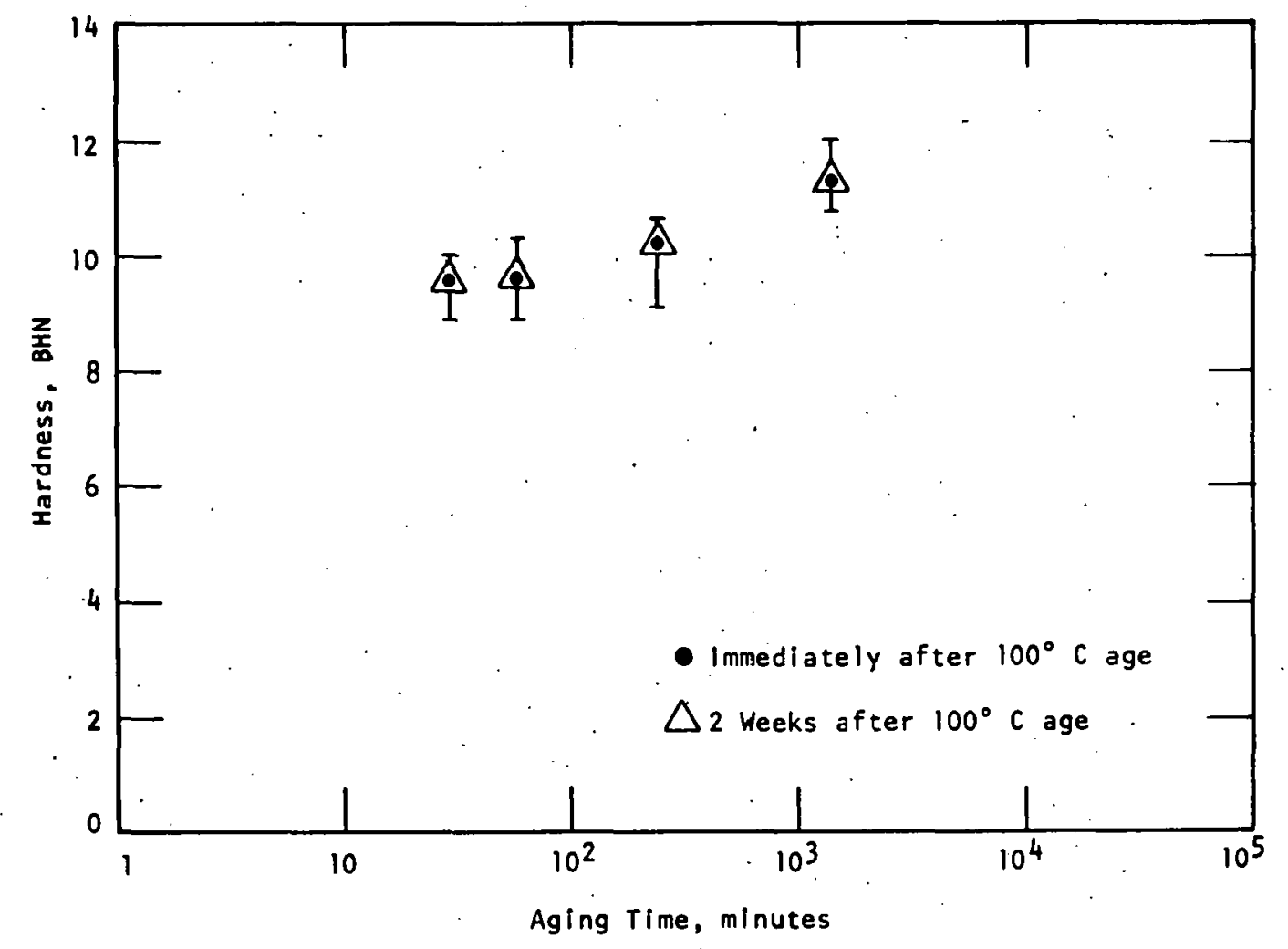

Figure 12. Hardness versus aging time at the elevated aging temperature for weld metal samples solution heat treated at. $300^{\circ} \mathrm{C}$ for two hours, water quenched, and aged at $100^{\circ} \mathrm{C}$. 


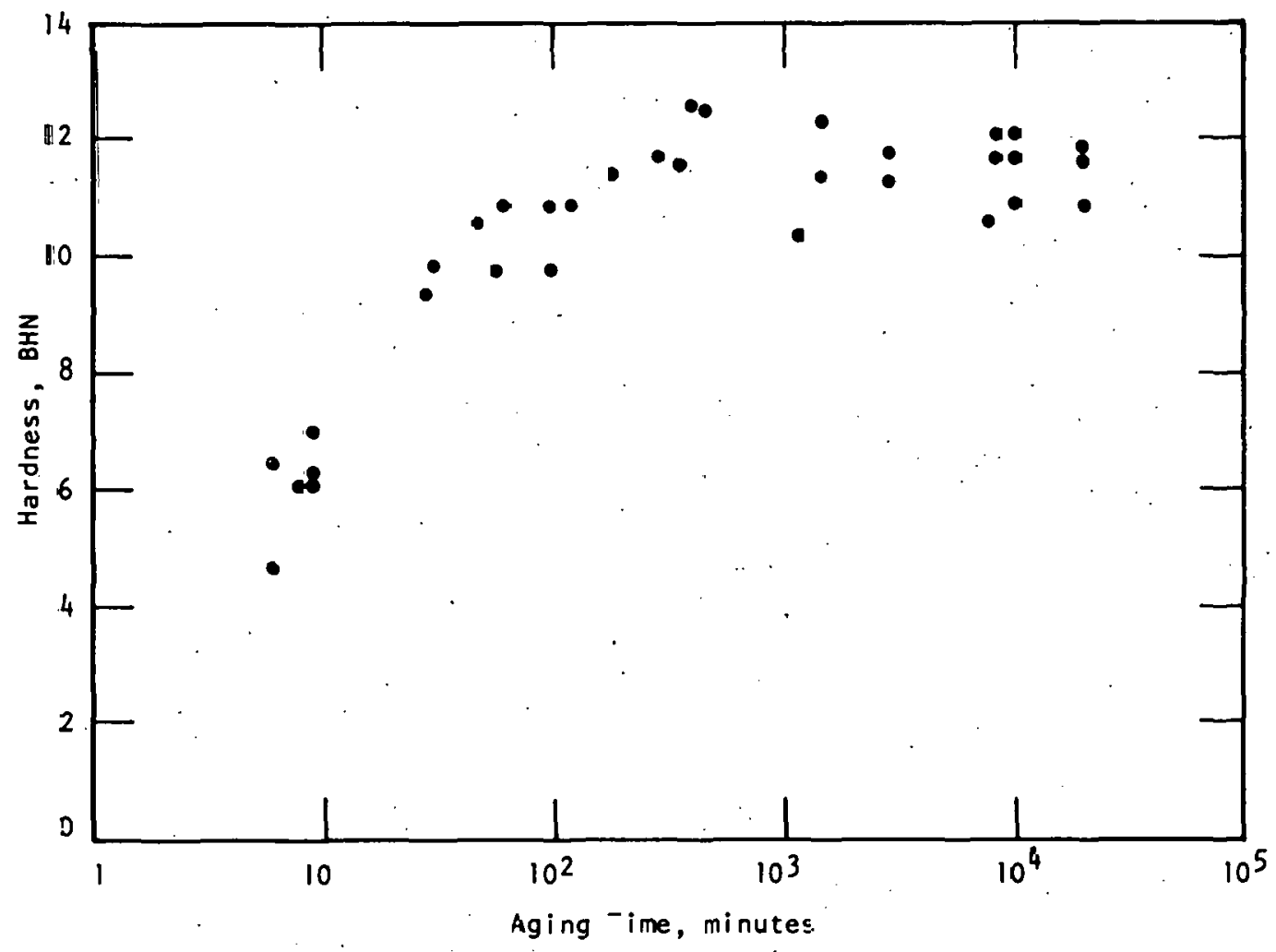

Figure 13. Hardness versus aging time for weld metal in the as-welded, and room temperature aged condition. 
To determine if base metal, fully hardened prior to welding, would indicate a decrease in hardness in the heat-affected zone after welding, microhardness data was obtained. Macrohardness measurements were not considered to be sensitive enough to determine hardness changes in the heat-affected zone because of the large indent area. Microhardness data was obtained by traversing from the base metal to the weld metal on transverse cross-sections of as-welded samples room temperature aged two weeks. A plot of the data obtained is shown in Figure 14. These data do not indicate a decrease in hardness in the base metal heat-affected zone. Overaging, which may have been expected to occur, dio not occur in the base metal heat-affected. zone during welding. Previously mentioned data from base metal samples solution heat treated at $300^{\circ} \mathrm{C}$ for two hours and aged at $100^{\circ} \mathrm{C}$ for 96 hours did not show indications of overaging. At temperatures greater than $100^{\circ} \mathrm{C}$. the rate at which overaging may occur increases. During welding, however, the time at a given temperature is much shorter than that during the $100^{\circ} \mathrm{C}$ aging treatment and is apparently not of sufficient length to cause overaging. Thus, welds can be made on previously fully hardened base metal without causing a degradation of the base metal hardness and these welds do not require subsequent solution heat treatment to obtain maximum hardness in the weld metal.

\section{Tensile Strength}

To determine if the tensile strength of the lead-calcium alloy would respond to heat treatment in a manner similar to that indicated 


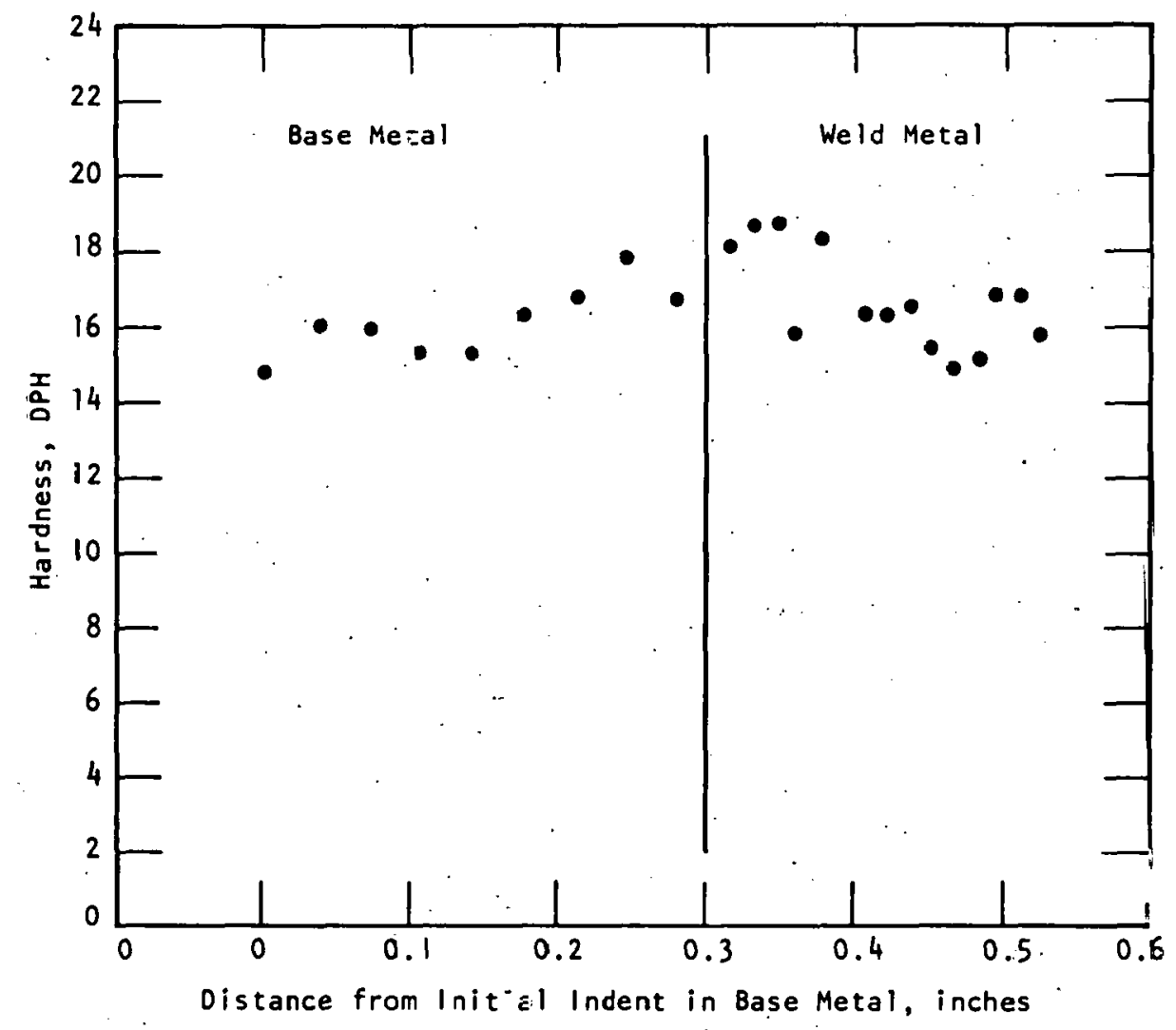

Figure 14. Hardness traverse in initially fully hardened base metal in the as-welded condition, two weeks after welding: 
by hardness tests, tensile coupons were prepared and tested. The tensile coupons were solution heat treated at $300^{\circ} \mathrm{C}$ for two hours, water quenched and aged at both room temperature and $100^{\circ} \mathrm{C}$. Some weld metal samples were evaluated in the as-welded and aged condition. Tensile properties were first characterized on base metal to provide data for later comparison with the tensile properties of weld metal and heat-affected zone. The results of all tensile studies are reported in Appendix $D$. The ultimate tensile strength was determined at various aging times following the solution heat treatment and water quench including, 10 and 30 minutes, 2, 6, 24 and 48 hours, 1 and 2 weeks. Yield strength was also measured at time intervals of 10 minutes, 2 and 48 hours. A plot of the ultimate tensile strength and yield strength is shown in Figure 15. The yield and ultimate tensile strength increases for longer aging times at a rate similar to hardness increases. Also, the yield strength is approximately one-half the ultimate strength at all aging times. The ultimate tensile strength and yield strength approached a maximum of approximately $5000^{\circ} \mathrm{ps} i$ and 2600 psi, respectively, after roon temperature aging one week: This is similar to the time required for base metal samples, similarly, heat treated and aged, to approach maximum hardness. Thus, the tensile strength of lead-calcium base metal increases in a manner similar to hardness when similar solution heat treatment and room temperature aging are used.

In order to determine the affect of elevated temperature aging, additional base metal, tensile samples were solution heat treated for two hours at $300^{\circ} \mathrm{C}$, water quenched and immediately aged at $100^{\circ} \mathrm{C}$. 


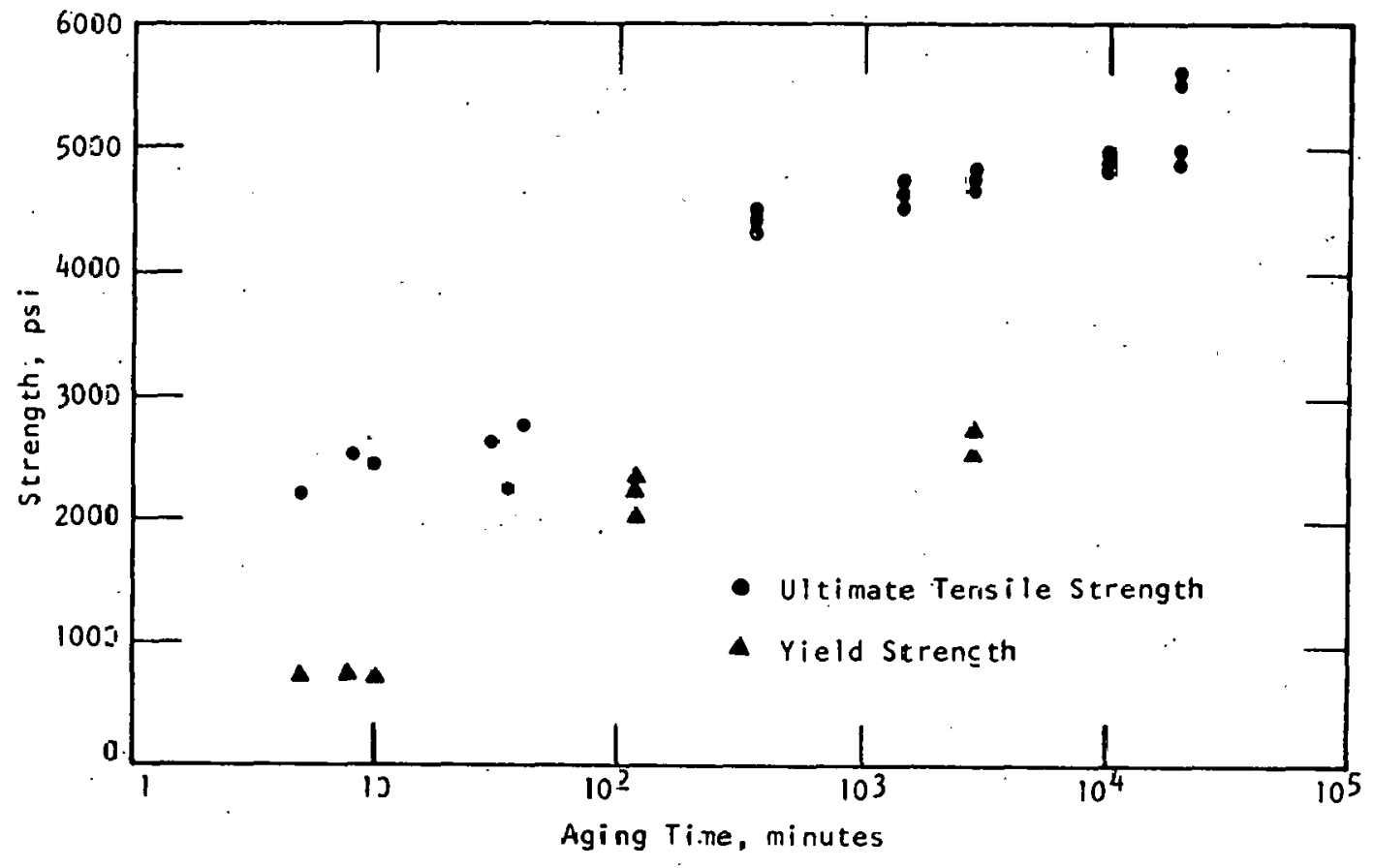

Figure 15. Tensile strergtt versus aging time for base metal samples solution heat treatec at $300^{\circ} \mathrm{C}$ for two hours, water quenched, and room temperature aged. 
Aging times of $1 / 2,1,4,24$ and 48 hours were used. Tensile strength data was obtained immediately following the $100^{\circ} \mathrm{C}$ aging temperature. A plot of this study is presented in Figure 16. The ultimate tensile strength shows a slight increase in strength from 4100 psi after a $30-$ minute aging time to 4600 psi after a 48-hour aging time. Hardness data indicated a similar gradual increase in hardness with longer aging times. The maximum ultimate tensile strength of 4600 psi reached for samples aged at $100^{\circ} \mathrm{C}$ is virtually the same as the $4700 \mathrm{ps} i$ reached for samples room temperature aged for 48 hours. These data indicate similar increases in tensile strength in response to both room temperature and $100^{\circ} \mathrm{C}$ aging.

In order to determine if weld metal would respond to increases in tensile strength in a manner similar to the base metal, longitudinalweld tensile samples were solution heat treated for two hours at $300^{\circ} \mathrm{C}$ water quenched and room temperature aged. The ultimate tensile strength and yield strength were determined at various times following the water quenching. A plot of the longitudinal-weld tensile data is shown in Figure 17. The ultimate tensile strength approaches'a maximum strength of 5000 psi after a one week room temperature age which is identical to the maximum strength and time required to reach maximum strength in base metal. The yield strength approaches a maximum of 3000 psi after an aging time of 48 hours which is greater than the maximum yield strength of 2600 psi reached in the base metal samples in the same time interval. 


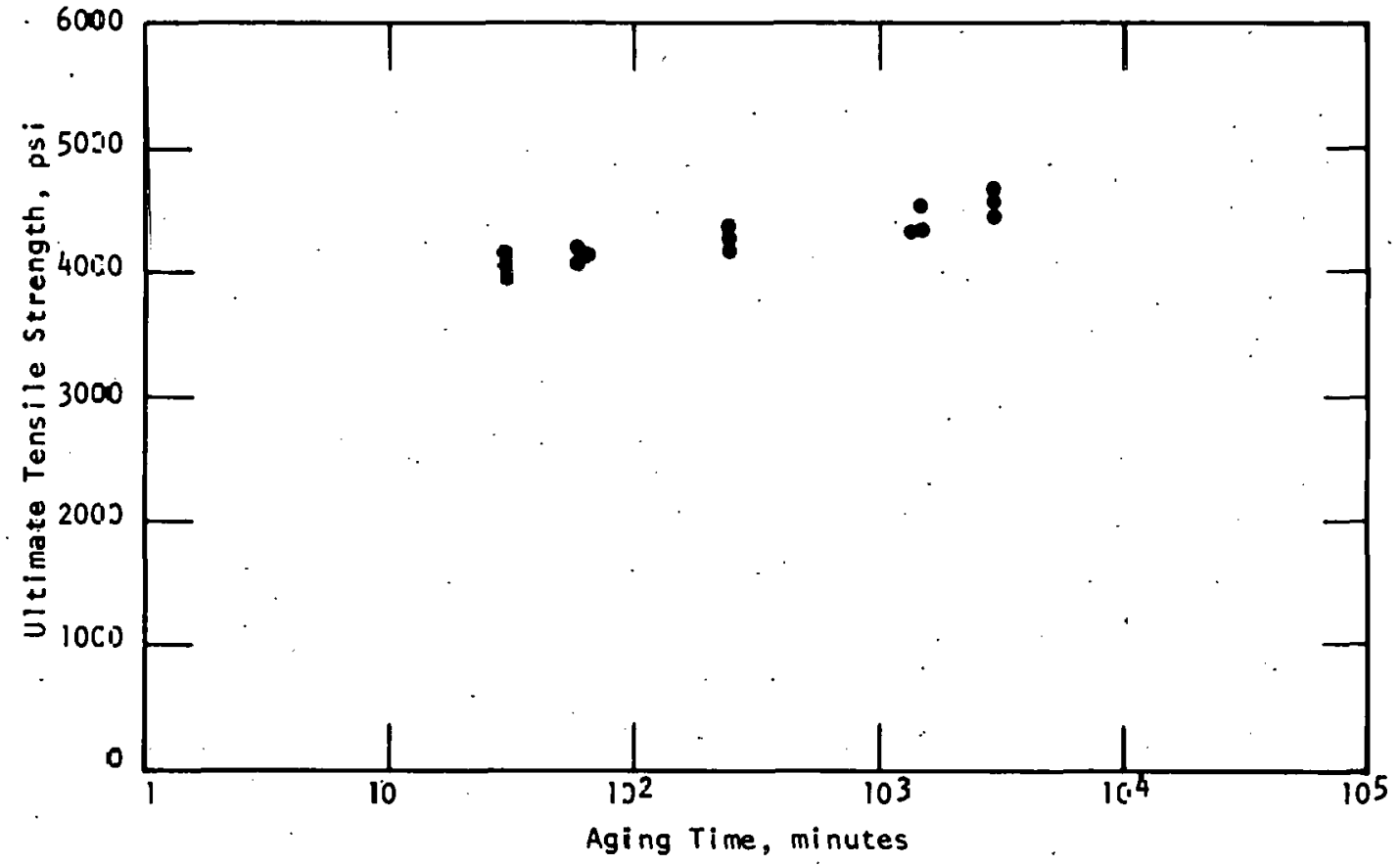

مे

Figure 16. Tensile strength versus aging time for base retal samples solution heat treated at $300^{\circ} \mathrm{C}$ for two hours, water quenched, and aged at $100^{\circ} \mathrm{C}$. 


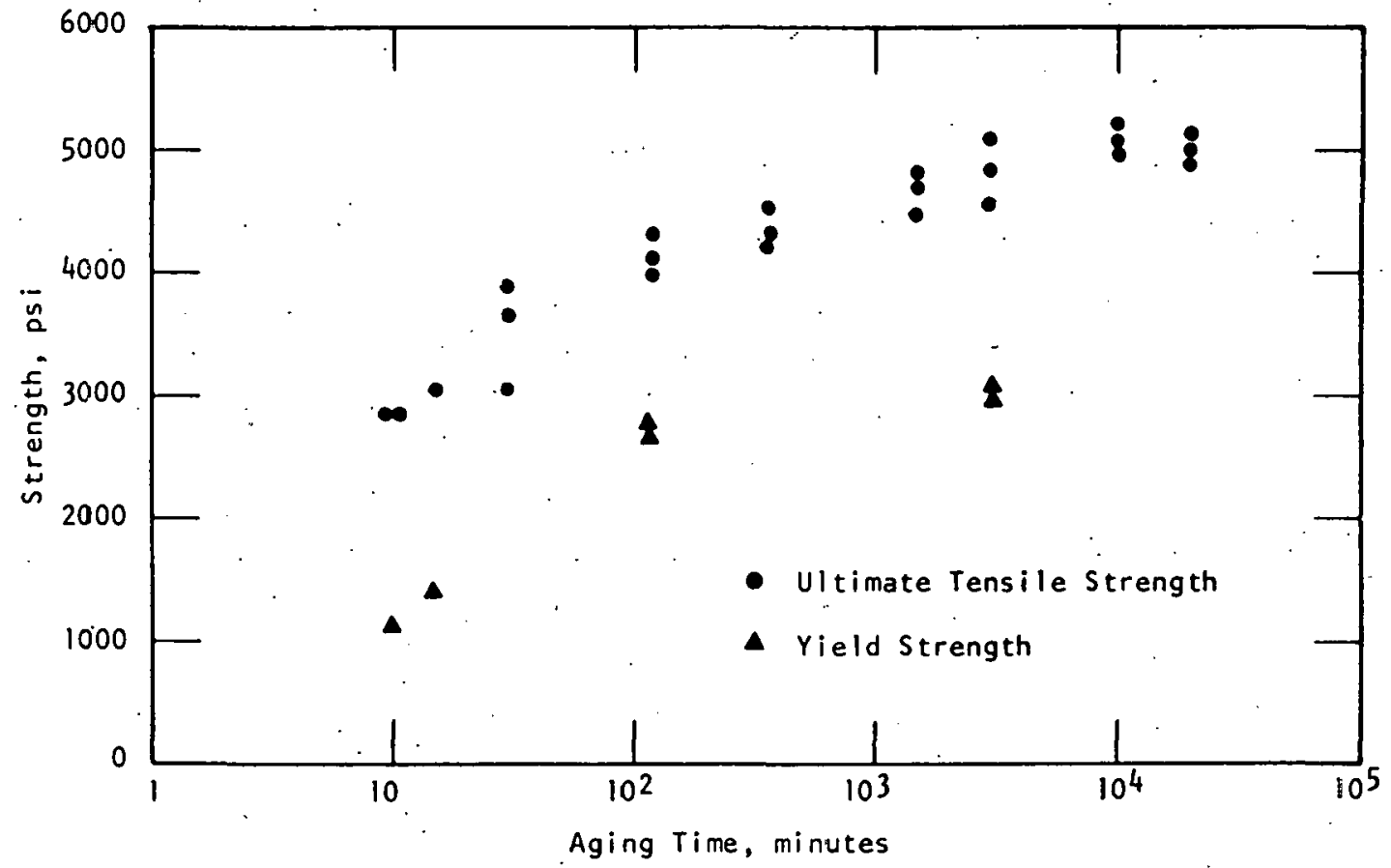

Figure 17. Tensile strength versus aging time for longitudinal-weld netal samples solution heat treated at $300^{\circ} \mathrm{C}$ for two hours, water quenched, and room temperature aged. 
To determine if weld metal would respond to an elevated temperature age in a manner similar to the base metal, longitudinal-weld tensile coupons were solution heat treated for two hours at $300^{\circ} \mathrm{C}$, water quenched and aged at $100^{\circ} \mathrm{C}$ for $1 / 2,1,4,24$ and 48 hours. Immediately following the elevated temperature age at the times indicated, the ultimate tensile strength was determined. A plot of the transverse-weld tensile data is shown in figure 18. The ultimate tensile strength shows a slight increase in strength from 4100 psi after a 30-minute aging time to 4700 psi after a 48-hour aging time. These data are virtually identical to that obtained for base metal samples similarly heat treated and aged. Thus, weld metal can be expected to respond to solution heat treatment and room temperature or elevated temperature age in a manner similar to base metal.

In order to determine if weld metal, room temperature aged immediately after welding, would respond in a manner similar to solution heat created and room temperature aged weld metal, additional longitudinalweld tensile coupons were prepared. Ultimate tensile strength data were obtained after a room temperature age of two weeks. The as-welded and aged coupons had an ultimate tensile strength of 5800 psi. This value is approximately 800 psi greater than similar samplcs given a solution heat treatment and room temperature age. The tensile data indicates that the solution heat treatment and room temperature age causes a slight degradation in the as-welded and room temperature aged weld metal. Hardness data, however, did not show indications of degradation in the weld metal hardness caused by the solution heat treatment and room temperature aging. 


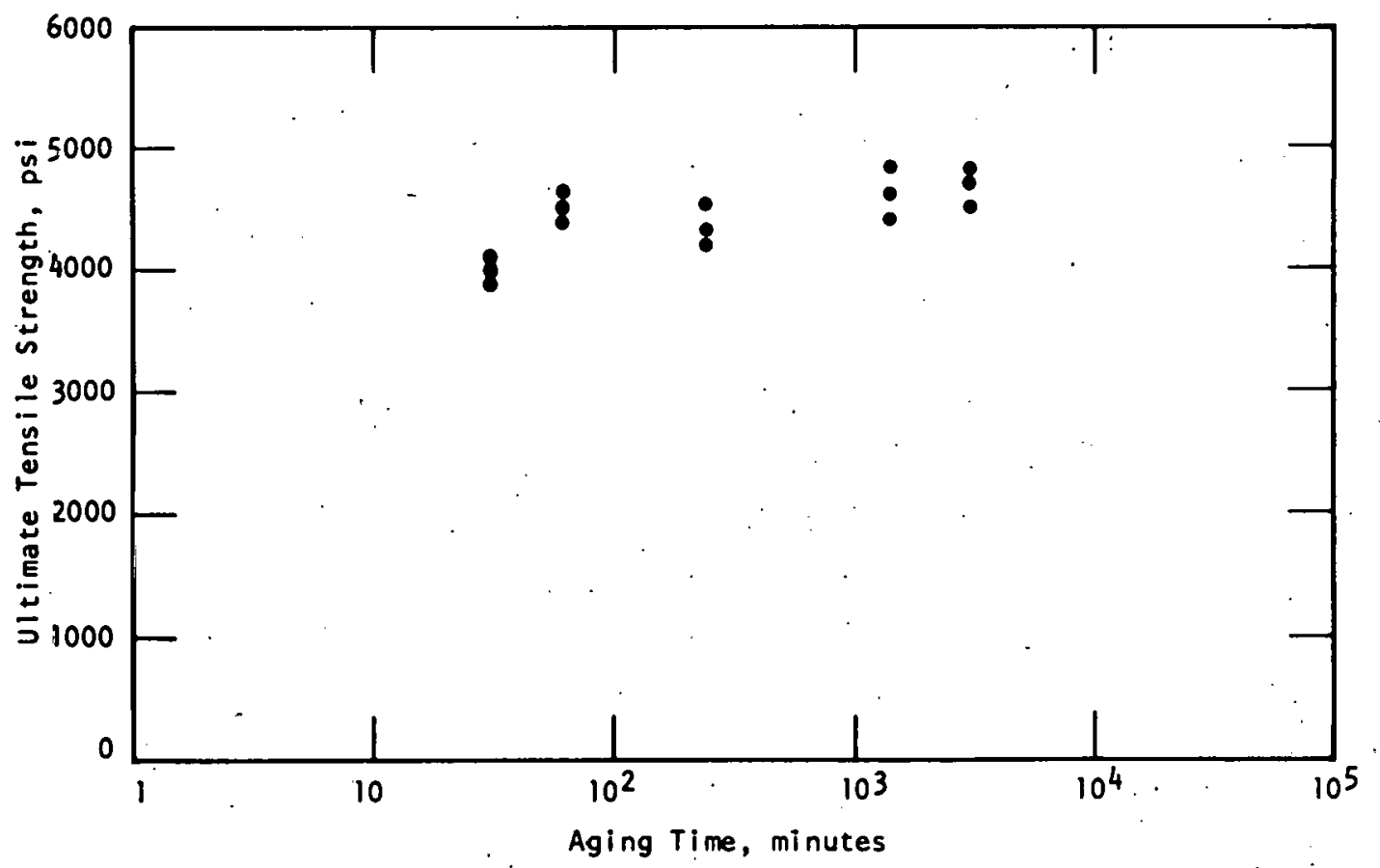

Figure 18. Tensile strength versus aging time for longitudinal-weld metal samples solution heat treated at $300^{\circ} \mathrm{C}$ for two hours, water quenched, and aged at $100^{\circ} \mathrm{C}$. 
To determine the tensile properties of the heat-affect zone, transverse-weld tensile coupons were prepared. Again, the tensile coupons were solution heat treated for two hours at $300^{\circ} \mathrm{C}$, water quenched and room temperature aged. The ultimate tensile strength was determined at various aging times identical to the aging times used in the base metal and weld metal evaluation. A plot of the transverse-weld tensile data is presented in Figure 19. The maximum ultimate tensile strength of 5000 psi reached after room temperature aging one week compares favorably with similarly heat treated and aged base metal and weld metal. However, in all but three of the transverse-weld tensile coupons tested, each failed in the heat-affected zone. The specimens apparently failed in the heat-affected zone because the weld metal has a slightly higher yield strength than the base metal when similarly heat treated and aged as previously indicated.

In order to determine the affect of an elevated temperature ago on the host-affected zone, tiansverseweld censile coupons were solution heat treated for two hours at $300^{\circ} \mathrm{C}$, water quenched and immediately aged at $100^{\circ} \mathrm{C}$. The transverse-weld tensile coupons were aged for $1 / 2,1,4,24$ and 48 hours. Immediately, following completion of the elevated temperature age, the samples were tested. A plot of the ultimate tensile strength versus aging time is shown in Figure 20 . These data indicate a gradual increase in ultimate tensile strength, similar to the longitudinal-weld coupons and base metal coupons similarly solution heat treated and aged. The maximum ultimate tensile 


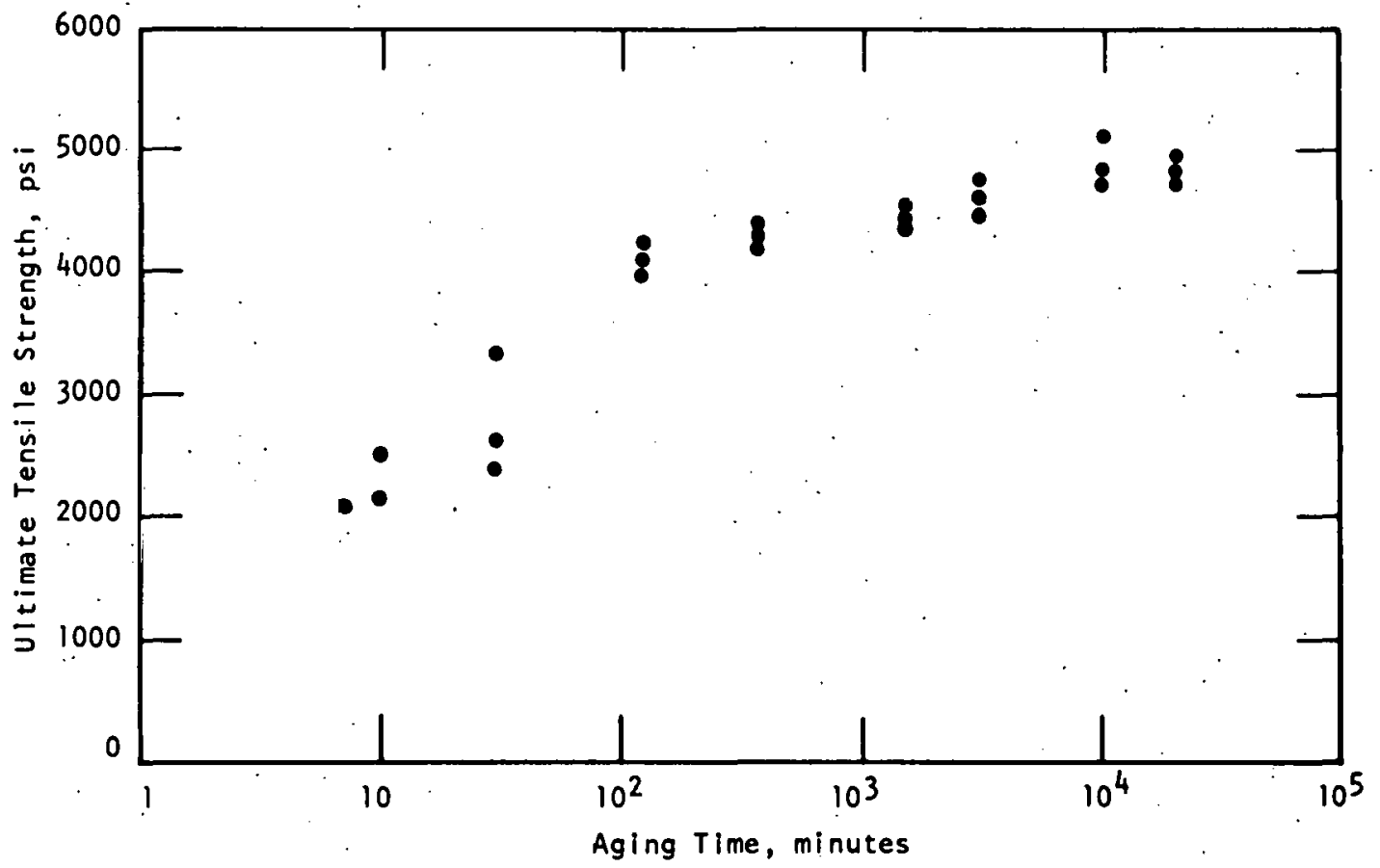

Figure 19. Tensile strength versus aging time for transverse-weld metal samples solution heat treated at $300^{\circ} \mathrm{C}$ for two hours, water quenched, and room temperature aged. 


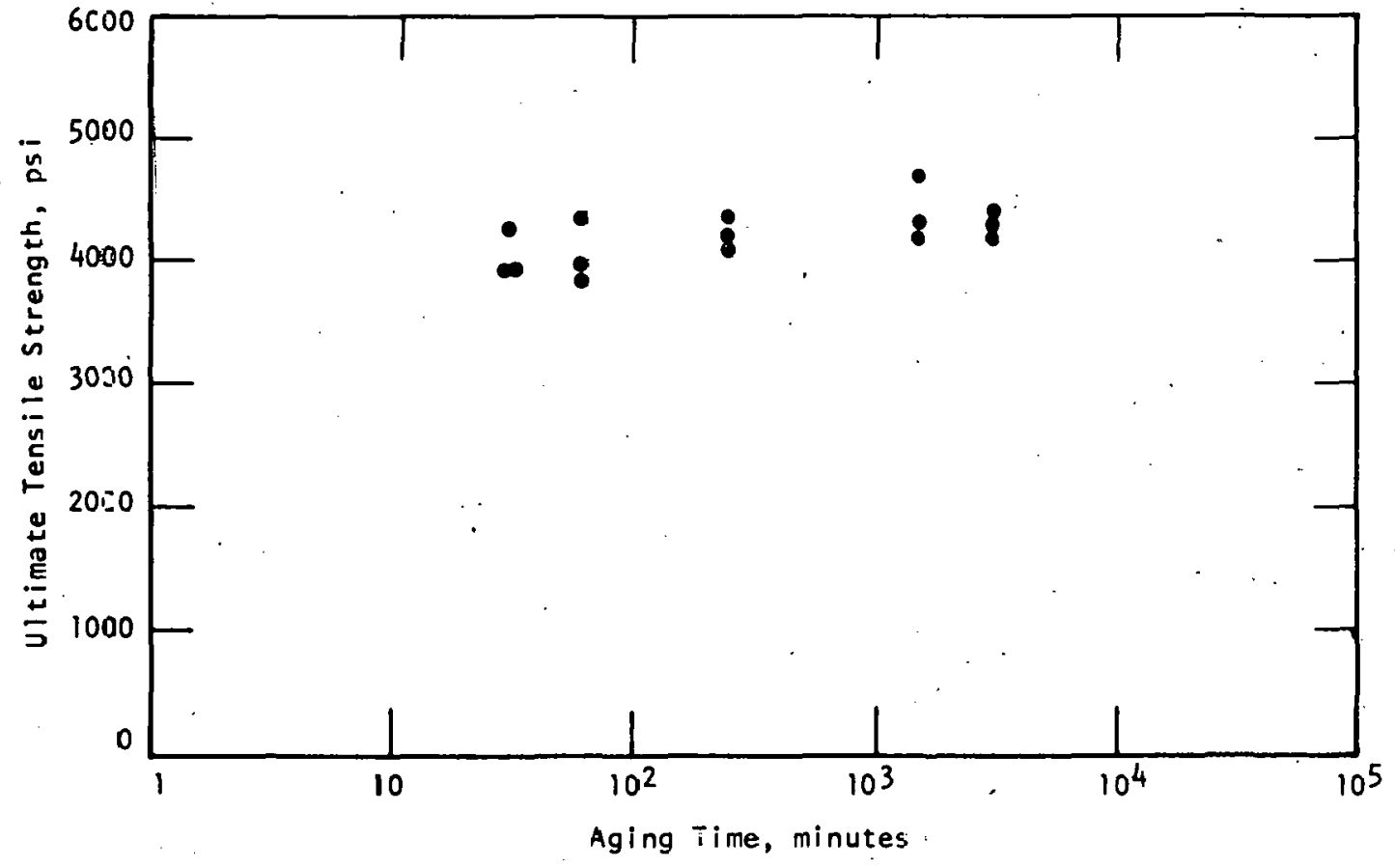

Figure 20. Tensile strength versus aging time for transverse-weld metal samples solution heat treated at $300^{\circ} \mathrm{C}$ for two hours, water quenched, and aged at $1010^{\circ} \mathrm{C}$. 
strength of 4500 psi reached after aging 48 hours is slightly lower than the 4600 psi and 4700 psi obtained with similarly solution heat treated and aged base metal and weld metal, respectively. Thus, the tensile strength in the heat-affected zone of the welded lead-calcium alloy can be expected to respond to solution heat treatment and aging at room temperature or $100^{\circ} \mathrm{C}$ in a manner similar to the weld metal and base metal.

To determine if the heat-affected zone, room temperature aged immediately after welding, would show a lowering of the tensile strengthi caused by the thermal cycling of the weld, transverse-weld tensile coupons were prepared. Ultimate tensile strength data were obtained after a room temperature age of two weeks. The as-welded coupons had an ultimate tensile strength of 4700 psi. This value compares with the ultimate tensile strength of the solution heat treated and room temperature aged base metal and weld metal samples. Also, these data indicate that the heat from welding does not cause a reduction in tensile strength of initially fully hardened base metal. Therefore, base metal, solution heat treated and aged prior to welding, can be welded and be expected to reach the initial base metal tensile strength after a two-week room temperature age without a solution heat treatment subsequent to welding.

\section{METALLOGRAPHY}

The lead-calcium alloy was found to be very difficult to prepare for metallographic examination. Because of the alloy's softness, 
polishing compounds became embedded in the sample. Also, if excessive pressure was applied during polishing, the sample tended to smear. These two problems created artifacts in the sample.

Oxidation of the etched surface also created many problems. Approximately one hour after etching, the etched surface was oxidized severely enough to mask the microstructure. Therefore, observation of the microstructure and obtaining of photomicrographs had to be accomplished within approximately one hour following etching. Some of the samples, even when observed immediately following etching, showed indications of light interference fringes apparently caused by a thin oxide forming on the surface. Thus, it was extremely difficult to characterize the microstructure.

For the lead-nominal 0.06 weight percent calcium alloy, a terminal solid solution exists at the eutectic temperature. Under equilibrium soliditication conditions the lead-calcium alloy would not contain any eutectic constituent. Generally, however, the alloy will probably contarif tise eutectic constituent whan soliditied. This is caused by nonequilibrium solidification which causes the average composition of the solid phase to depart from that indicated by the solidus such that freezing is not complete before the eutectic temperature is reached. The alloy may be brought to equilibrium after solidification by subjecting it to an extended exposure at a temperature between the solvus and solidus. Thus, a solution heat treatment would be expected to homogenize the solidification structure and therefore 
mask the solidification history. To characterize the base metal and weld metal, a sample was solution heat treated for two hours at $300^{\circ} \mathrm{C}$, water quenched and room temperature aged for two weeks. Photomicrographs of the base metal are shown in Figure 21 and the weld metal photomicrographs are shown in Figure 22. In the 100X magnification micrographs in both figures the light interference fringes apparently caused by a thin oxide film on the surface can be observed. It can also be observed that the grain size is approximately the same for both the base metal and weld metal. In the $750 x$ magnification micrographs in both Figure 21 and Figure 22 a lamellar structure can be observed. The lamellar structure may be present for two reasons. First, the solidification structure, which could have been a lamellar eutectic structure, may have not been homogenized during the solution heat treatment. This seems unlikely since the material was within approximately $27^{\circ} \mathrm{C}$ of the melting temperature for a relatively long time at the solution heat treating temperature. Second, the lamellar structure may be caused by the lead-calcium precipitate forming on certain habit planes which in turn causes preferential attack by the etching solution. To substantiate this argument an electron microprobe analysis was performed on the sample. The lamellar width is approximately that of the diameter of the electron beam. However, calcium rich areas ( $\mathrm{Pb}_{3} \mathrm{Ca}$ eutectic phase and/or precipitate) were not observed. In addition, the rather low calcium level in the alloy may be approaching the lower limit of detection by the electron microprobe. 


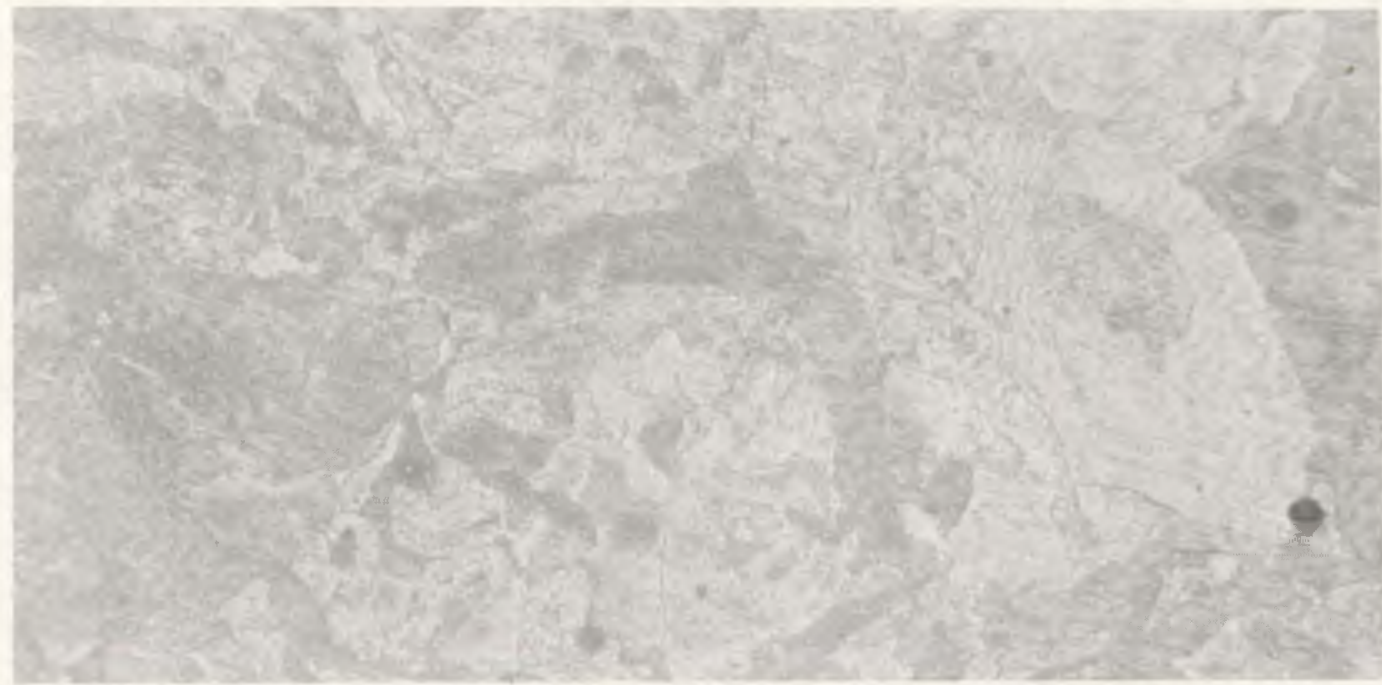

(a) $100 x$

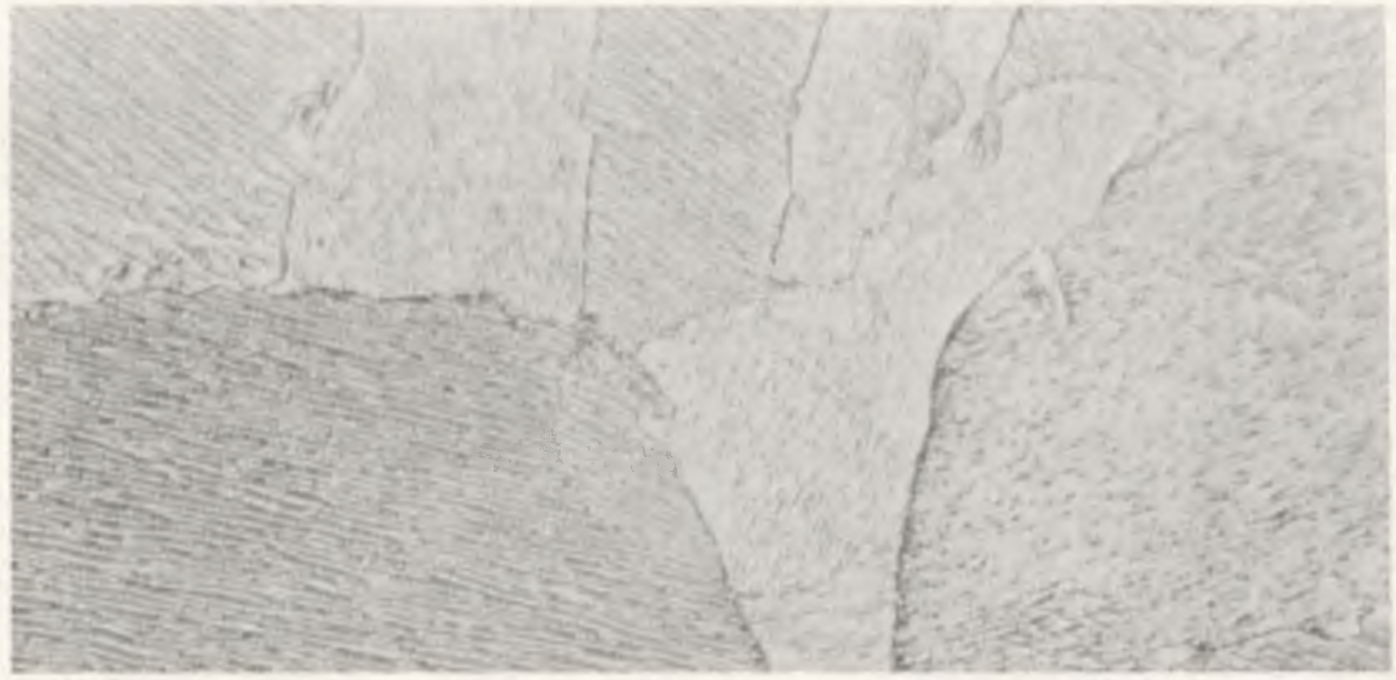

(b) $750 x$

Figure 21. Photomicrograph of base metal in a welded specimen solution heat treated at $300^{\circ} \mathrm{C}$ for two hours, water quenched, and room temperature aged for two weeks (acetic acid, hydrogen peroxide and ethyl alcohol). 


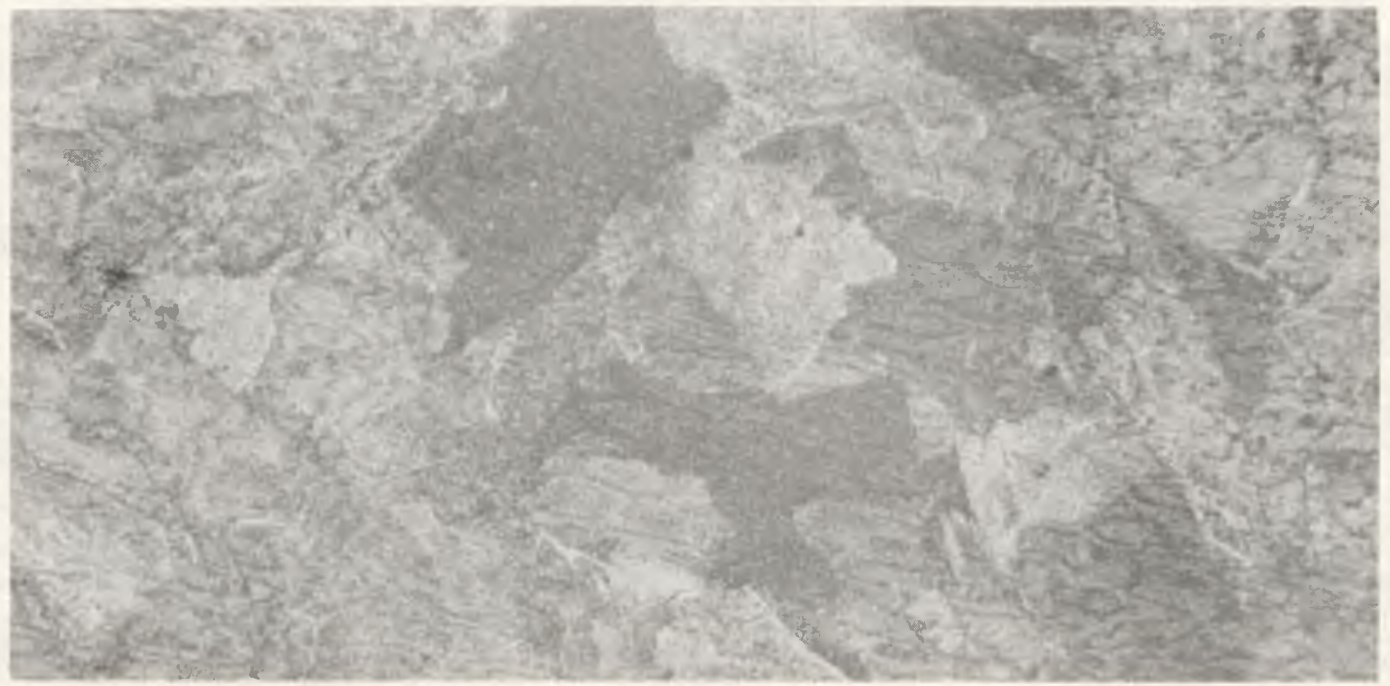

(a) $100 x$

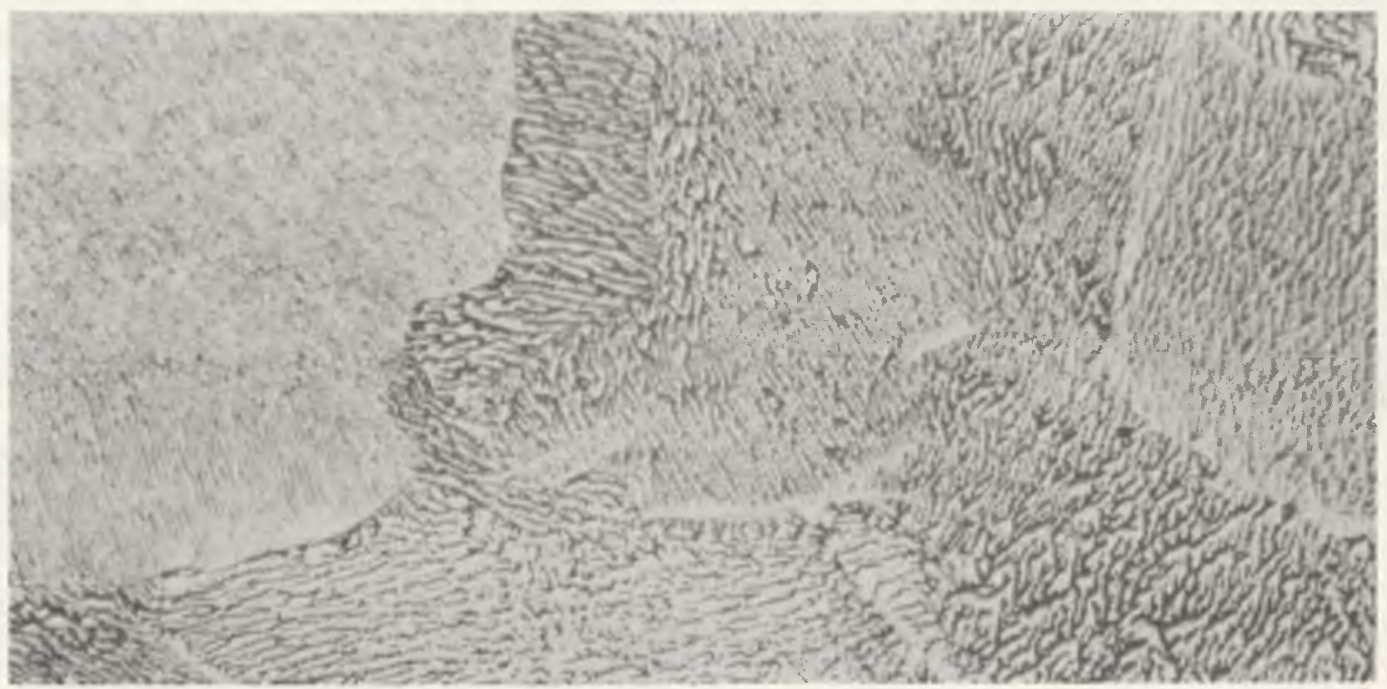

\section{(b) $750 x$}

Figure 22. Photomicrograph of weld metal solution heat treated at $300^{\circ} \mathrm{C}$ for two hours, water quenched, and room temperature aged for two weeks (acetic acid, hydrogen peroxide and ethyl alcohol). 
Metallographic analysis was also performed on a sample solution heat treated at $300^{\circ} \mathrm{C}$ for two hours, water quenched and aged at $100^{\circ} \mathrm{C}$ for 48 hours. Photomicrographs of the base metal are shown in Figure 23 and photomicrographs of the weld metal are shown in Figure 24. As with the previously discussed sample, light interference fringes can be observed in the 100x micrographs of the base metal and weld metal. The base metal and weld metal appear to have the same structure when observed in the 750x micrographs and the structure is essentially the same as that in the previously discussed sample. Thus, as would be expected, the different aging treatments did not have any apparent influence on the microstructure.

To determine if the weld metal in the as-welded condition would indicate the solidification history, an as-welded sample room temperature aged for two weeks was prepared for metallographic analysis. Base metal photomicrographs are shown in Figure 25 and weld metal photomicrographs are shown in Figure 26. As can be observed, the base metal and weld metal have the same structure which is essentially identical to the structure of the solution heat treated and aged samples. Since all of the structures are identical it appears that aging with or without prior solution treatment is obscuring any solidification history, solicification in the planar growth made is occurring or the metallographic techniques are such that structures resulting from solidification are not revealed. The former and the latter may be operating in consort to obscure the prior solidification history since the planar growth mode would not be expected in this alloy. 


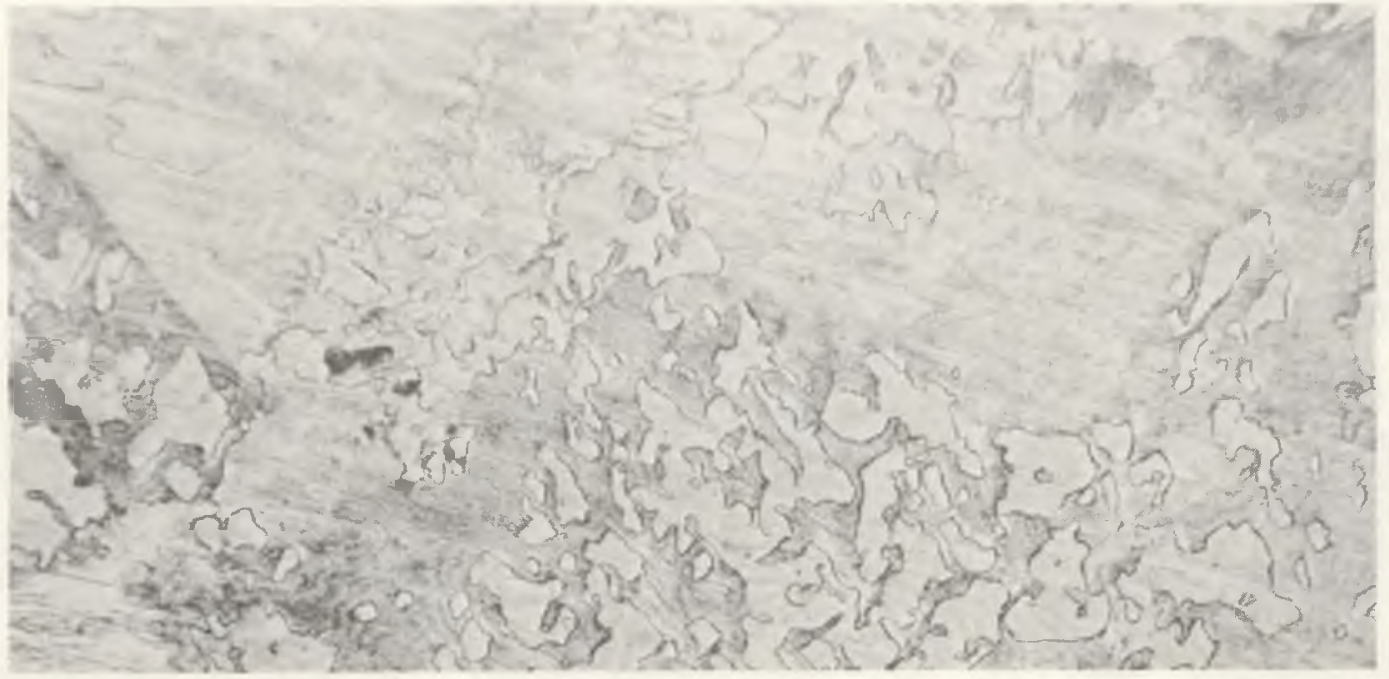

(a) $100 x$

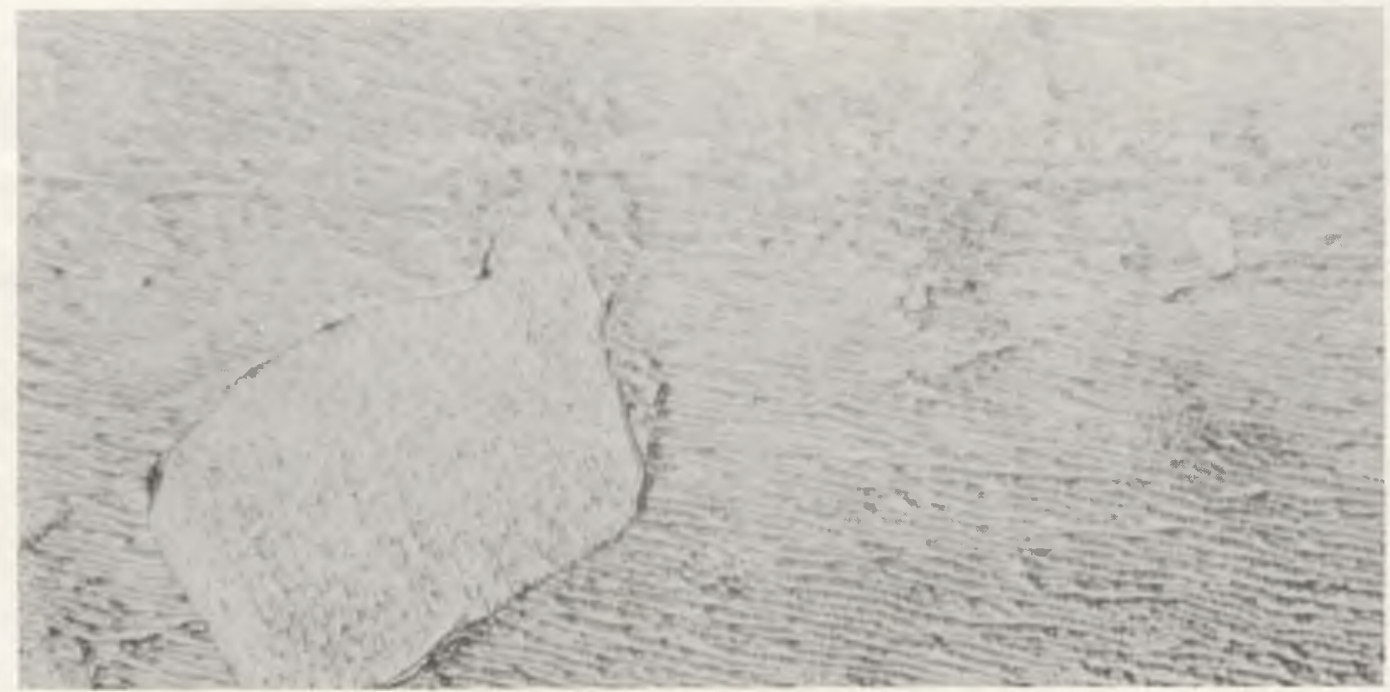

(b) $750 x$

Figure 23. Photomicrograph of base metal in a welded specimen solution heat treated at $300^{\circ} \mathrm{C}$ for two hours, water quenched, and aged at $100^{\circ} \mathrm{C}$ ror 48 hours (acetic acid, hydrogen peroxide and ethyl alcohol). 


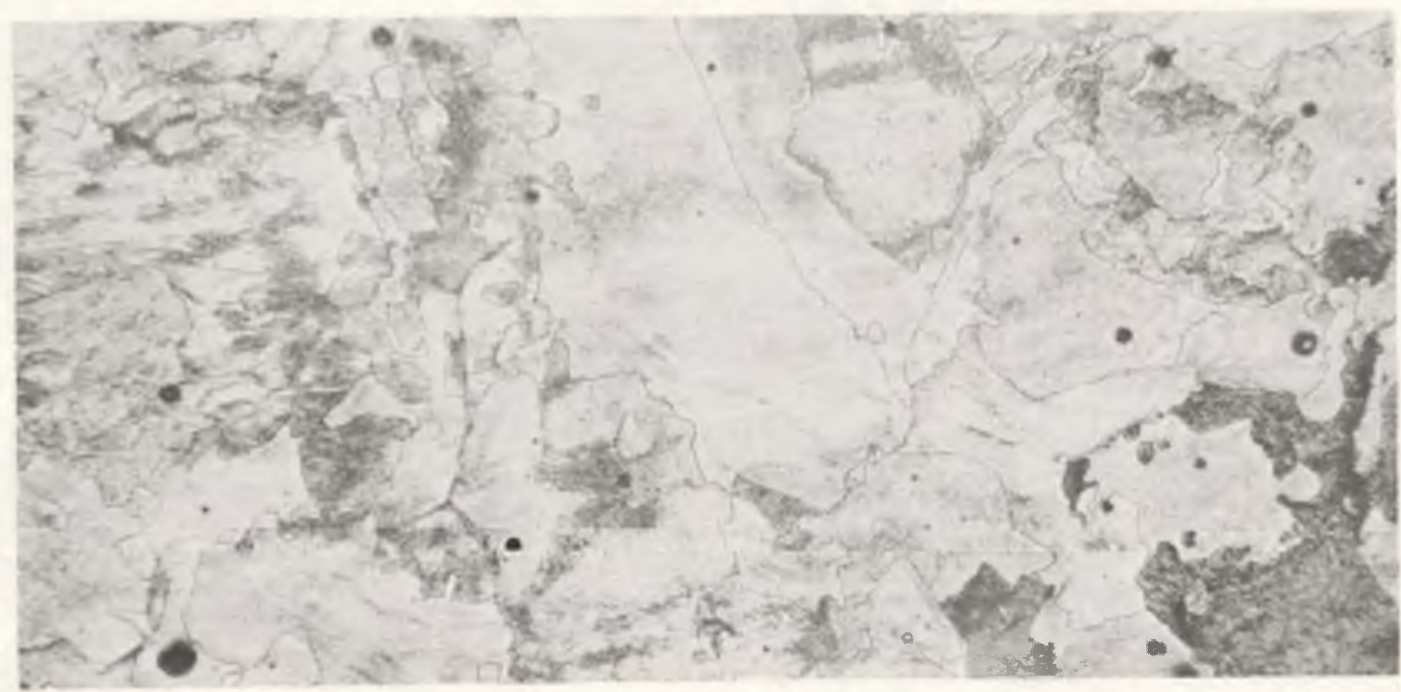

(a) $100 x$

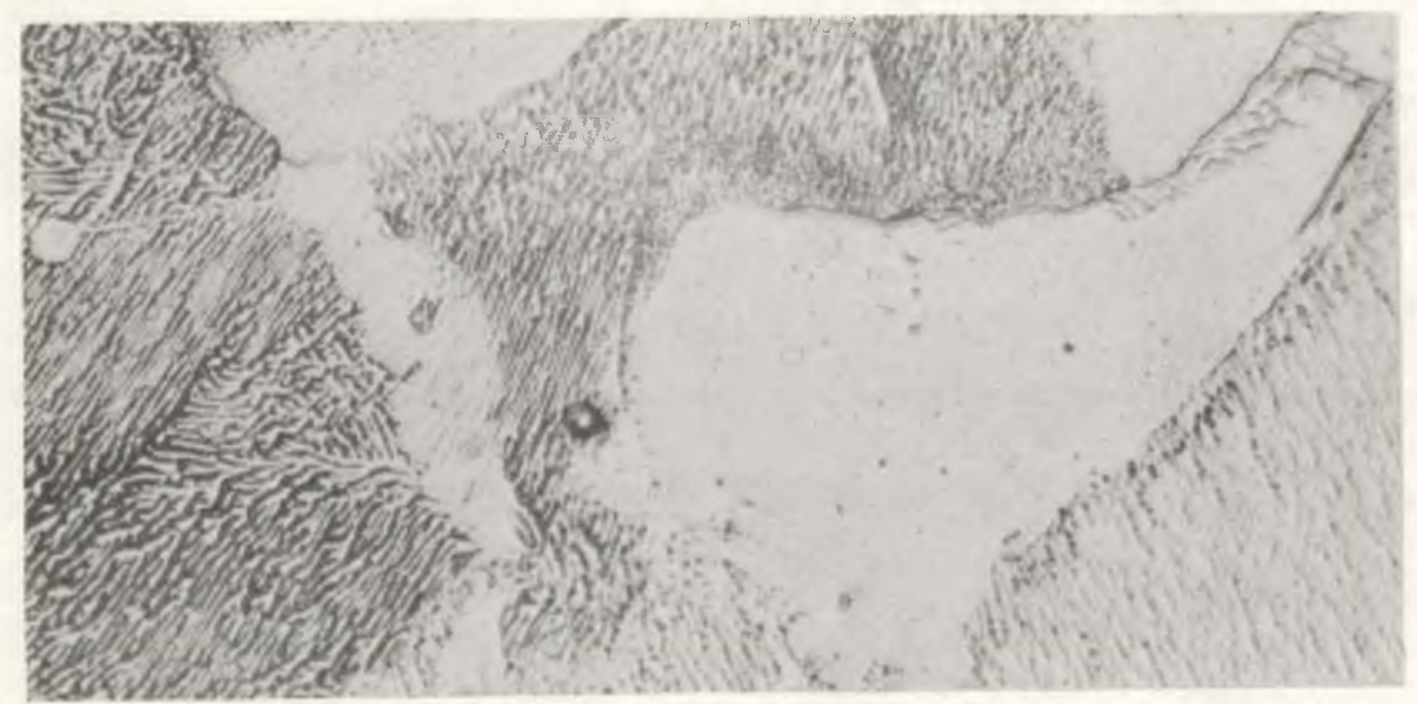

(b) $750 x$

Figure 24. Photomicrograph of weld metal solution heat treated at $300^{\circ} \mathrm{C}$ for two hours, water quenched, and aged at $100^{\circ} \mathrm{C}$ for 48 hours (acetic acid, hydrogen peroxide and ethyl alcohol). 


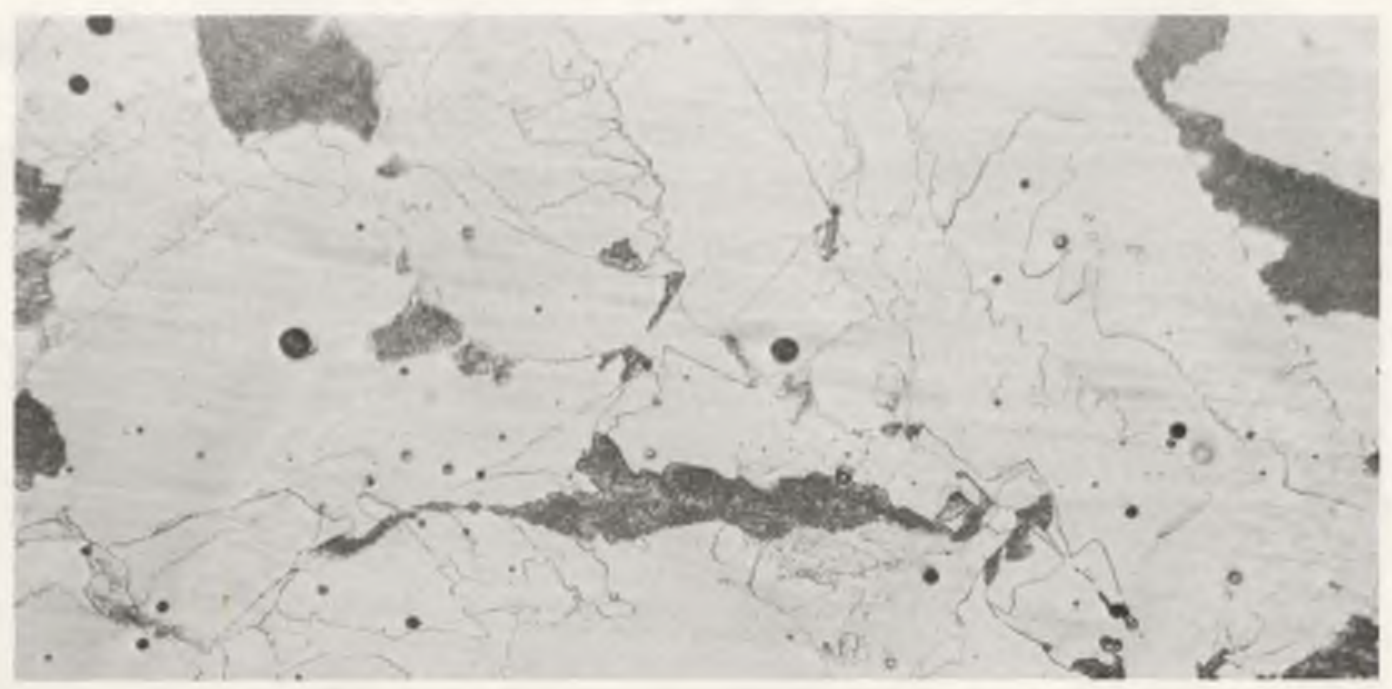

(a) $100 x$

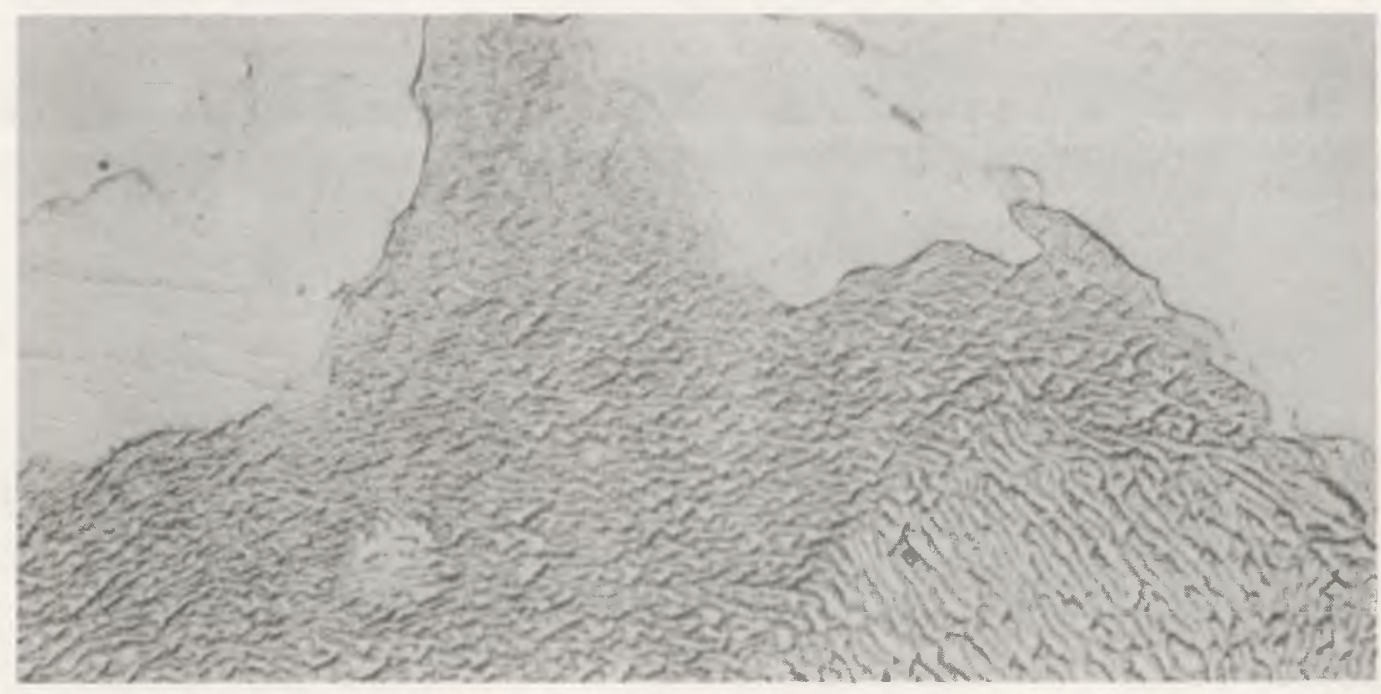

(b) $750 x$

Figure 25. Photomicrograph of initially fully hardened base metal in a welded specimen in the as-welded condition, room temperature aged for two weeks (acetic acid, hydrogen peroxide and ethyl alcohol). 


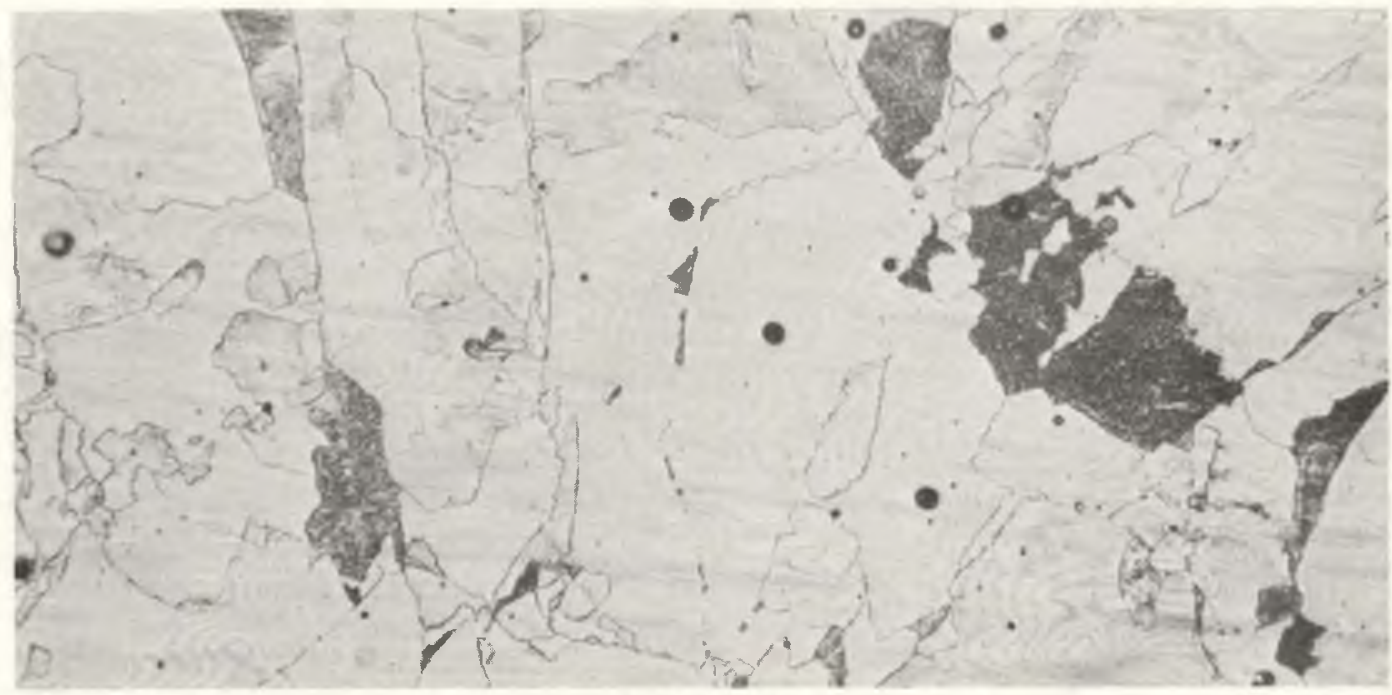

(a) $100 x$

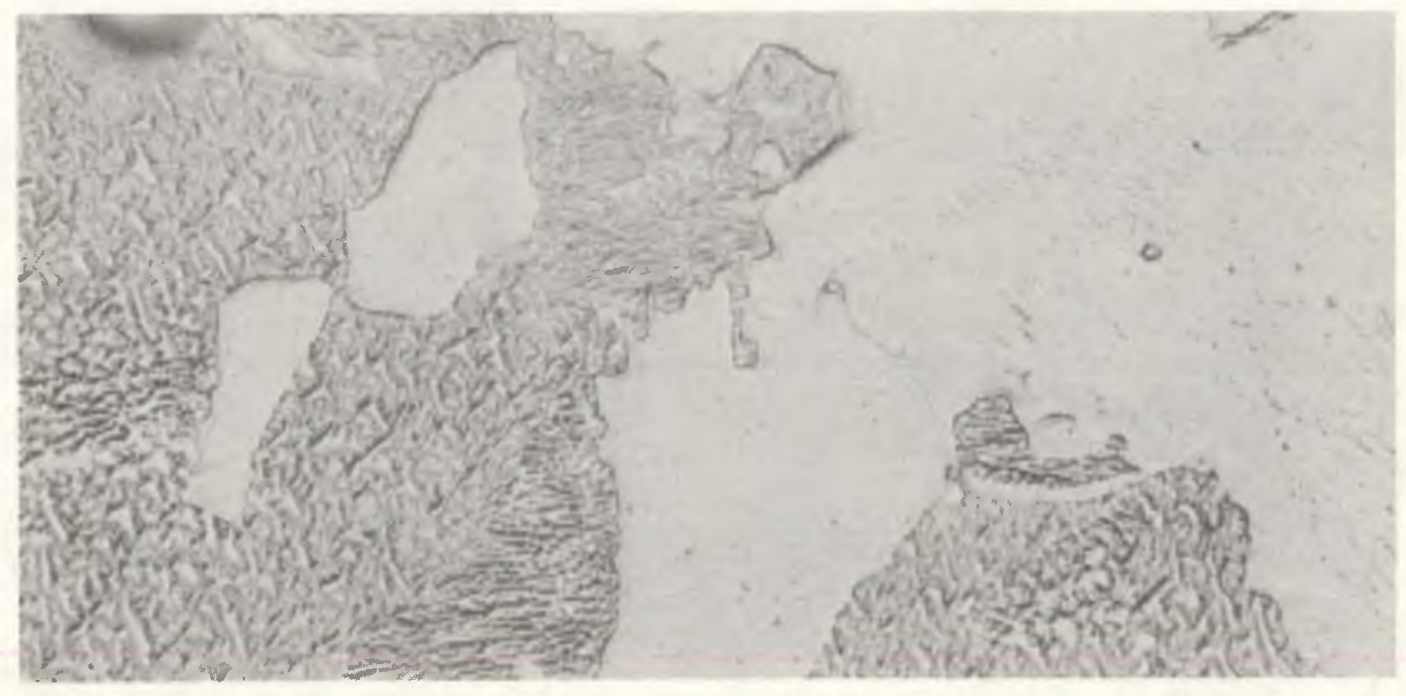

(b) $750 x$

Figure 26. Photomicrograph of weld metal in the as-welded condition, room temperature aged for two weeks (acetic acid, hydrogen peroxide and ethyl alcohol). 


\section{Electron Microprobe}

To determine the distribution of calcium in the lead-calcium alloy and to identify the lamellar structure observed in the optical metallographic analysis, samples were subjected to electron microprobe analysis. The samples used in electron microprobe analys is were the same as those used for the optical metallographic analysis. The samples were examined for calcium distribution in the base metal, weld metal and heat-affected zone. There was no apparent difference in the calcium distribution on any of the samples in the base metal, weld metal or heat-affected zone. The calcium appeared to be uniformly distributed throughout the samples with no enriched inclusions apparent. The calcium content was observed to vary from 0.04 to 0.07 weight percent which was essentially identical to the calcium variation determined by the atomic absorption technique.

\section{Scanning Electron Microscopy}

Most of the tensile coupons failed in a ductile knife-edge manner. However, a few of the coupons fractured before complete necking. These fractured surtaces appeared to exhibit porosity and were therefore examined by scanning electron microscopy. Figure 27 represents a fractograph from the base metal and Figure 28 represents a fractograph from the weld metal. As can be observed, the fractographs indicate that porosity was not present. Failure appeared to occur in a ductiledimple manner. The dark holes appearing in the fractographs were too deep to be observed with the scanning electron microscope. The deep 


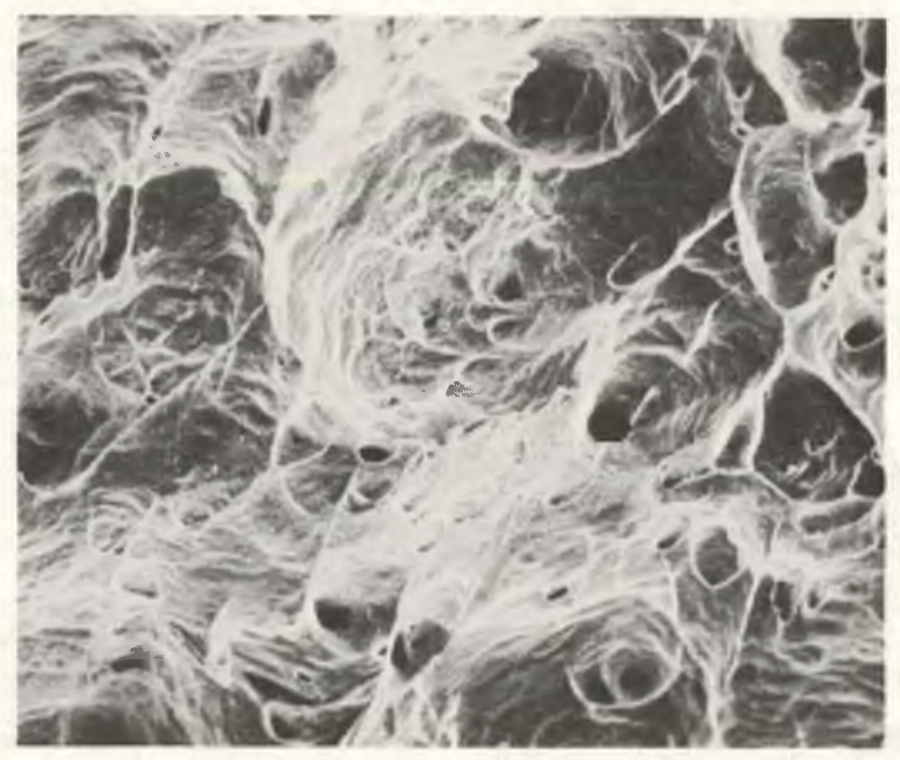

Figure 27. Scanning electron micrograph of a fractured base metal tensile coupon (300X). 


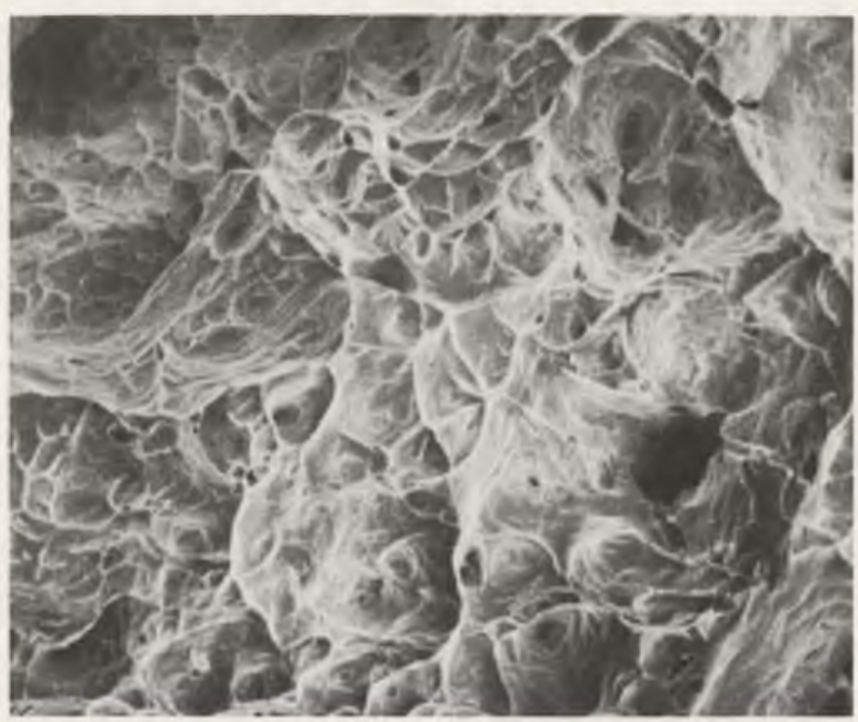

Figure 28. Scanning electron micrograph of a fractured weld metal tensile coupon (300x). 
holes may be caused by localized premature ductile-dimple failure followed by a large amount of plastic yielding prior to the sample failure. In a few isolated locations on the fractured surface, indications of porosity were observed. Figure 29 is a 1000x micrograph of an apparent pore. As can be observed in the micrograph, as many as 12 ductile-dimple ridges terminate on the ductile-dimple ridge surrounding the pore. Also, indications of ripples are observed on the surface of the pore. A solidification structure, however, is not apparent in the fractograph.

A sample not welded at the root of the weld was fractured such that the root of the weld could be examined with the scanning electron microscope. An 1000x micrograph shown in Figure 30 is in an area just beneath the fused metal. As can be observed in the micrograph, the surface of the pore is covered by what appears to be a brittle coating. The coating is probably oxide which formed after welding.

Although areas on the fractured surface did not reveal the solidification history, the scanning electron microscope proved to be a useful tool by direct observation of porosity and apparent oxidation in the lead-calcium alloy. 


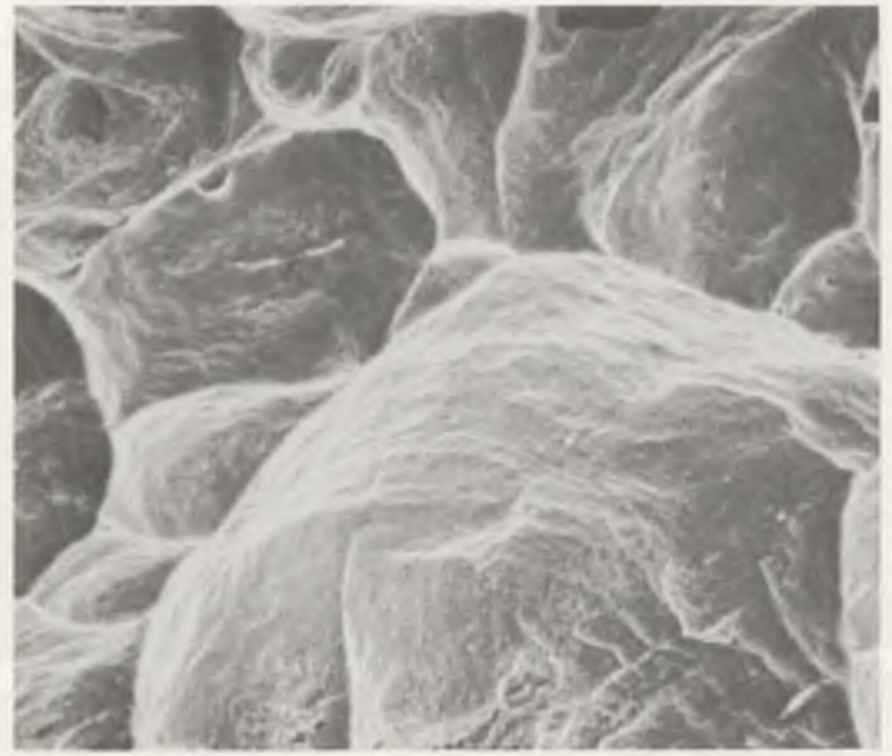

Figure 29. Scanning electron micrograph of an isolated pore (1000X). 


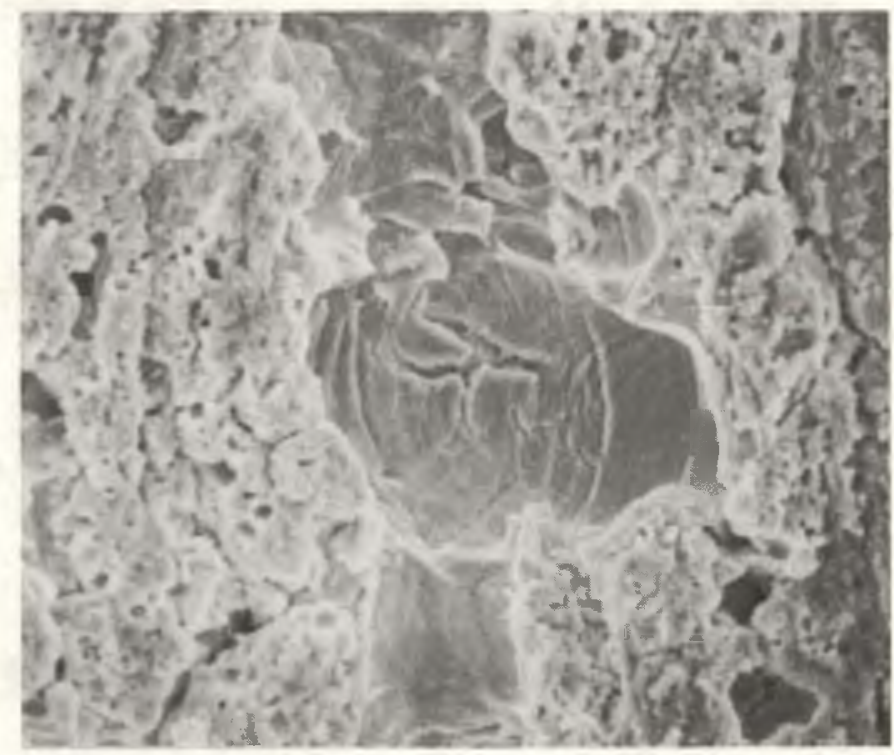

Figure 30. Scanning electron micrograph of area just below the weld root in unfused metal (1000x). 


\section{CONCLUSIONS}

Welding

1. The gas tungsten-arc alternating current welding process was determined to be capable of welding the lead-nominal 0.06 weight percent calcium alloy without producing calcium losses in the weld metal. The welding process also permitted fusion of the molten metal and resulted in a smooth weld bead.

2. Welding parameters were developed for single pass welds in 1/4-inch-thick lead-nominal 0.06 weight percent calcium.

3. Material thicknesses greater than $1 / 4$ inch thick require multiplę pass welds.

4. A backing material is required during welding to prevent molten metal drop through.

5. The material should be positioned such that the weld is made with a slight up-hill slope. This is to prevent the molten metal from flowing under the joint ahead of the arc and solidifying in the backing groove. This causes an effective increase in material thickness which prevents proper penetration.

\section{Properties}

1. The lead-nominal 0.06 weight percent calcium alloy responds to solution heat treatment and aging. 
2. Room temperature aging and $100^{\circ} \mathrm{C}$ aging produce a hardness approximately three times that of solution heat treated and quenched material and approximately two times that of overaged material.

3. Room temperature aging and $100^{\circ} \mathrm{C}$ aging produce essentially identical hardness and tensile strength characteristics.

4. For material room temperature aged, two weeks are required to reach maximum hardness, ultimate tensile strength and yield strength. 5. For material aged at $100^{\circ} i$ only 48 hours are required to reach maximum hardness and strength.

6. Two hours at $300^{\circ}$. C was determined to be adequate for solution heat treating.

7. Weld metal mechanical properties responded in a manner identical to the base metal mechanical properties when the material was heat treated and aged.

8. As-deposited weld metal (room temperature aged) mechanical properties also responded in a manner identical to solution heat treaced and aged base metal and weld metal.

9. Mechanical property degradation did not occur in the weld metal or heat-affected zone as a result of thermal excursions during welding.

10. A solution heat treatment is not required after welding to achieve maximum and identical mechanical properties in all weld zones if a two-week aging time is permitted. 
Summary

1. The lead-nominal 0.06 weight percent calcium alloy can be welded by the gas tungsten-arc alternating current process. The resulting weld metal and heat-affected zone responds to heat treatment and aging in a manner similar to base metal.

2. If fully hardened base metal is welded and subsequently aged at room temperature in the as-welded condition for approximately two weeks, maximum and identical mechanical properties are reached throughout the weldment.

\section{RECOMMENDATIONS}

1. Data reported by various authors indicate that the mechanical properties of the lead-calcium alloy are strongly influenced by the calcium content. Since this study was limited to a single nominal calcium composition, it is recommended that this work be extended to determine the mechanical properties of weld metal for various calcium compositions.

2. This study was limited to single pass welds. It is therefore recommended that this study be extended to multiple pass welds and the affect of multiple pass welds on mechanical properties and microstructures.

3. Much difficulty was encountered during the metallographic evaluation in this study. It is therefore recommended that this study be extended to develop a better metallographic technique for polishing and etching so that the solidification history can be more clearly defined. 
THIS PAGE

WAS INTENTIONALLY LEFT BLANK 


\section{LIST OF REFERENCES}

1. Elliott, R. P., Constitution of Binary Alloys, First Supplement, 245-246, McGraw-Hill Book Company, Inc., New York (1965).

2. Schumacher, E. E., and Bouton, G. M., "Age Hardening Lead-Calcium Alloys," Metals and Alloys, I, 405-409 (1930).

3. Dean, R. S., and Ryjord, J. E., "Alloys for Cable Sheathing," Metals and Alloys, $\stackrel{1}{=}, 410-414$ (1930).

4. Schumacher, E. E., and Phipps, G. S., "Some Physical and Metallurgical Properties of Lead-Calcium Alloys for Storage Cell Grids and Plates," Transactions of the Electrochemical Society, 68, 309-316 (1935).

5. Townsend, A. B., "The Effect of Casting Variables and Heat Treatment on the Tensile Properties of Lead-Calcium Alloys," U. S. Atomic Energy Commission, Y-1307, 1-25 (1960).

6. Garten, W., "Joining Lead-Calcium Alloy Used for Storage-Battery Plates," German Patent 694,183, June 27, 1940.

7. Garten, Wo, "Soldering Alloys of Lead and Calcium," French Patent 833,420 , October 21 , 1938 .

8. Hoehne, E., and Schweinitz, H. D.V., "The Behavior of Positive P.lates with Grids of Lead-Calcium Ảlloy in the Lead Storage Battery," Metallwirtschaft, 21, 218-23 (1942).

9. Abe, E., "Welding of Lead-Calcium Alloys Used for Storage Batteries," Japanese Patent 8370, September 28, 1956.

\section{Other References}

Briggs, J. Z., "An Extended Abstract on Calcium-Lead Alloys," Metals and Alloys, 9 , 2, 49-50 (1938).

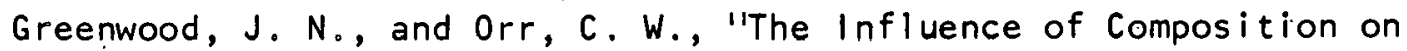
the Properties of Lead. IX. The Influence of Calcium," Proceedings Australasian Institute of Mining and Metallurgy, 112 , 287-300 (1938).

Hariba, H., "Age-Hardening of Lead Alloys," Sumitomo-Densen Iho, 1 , 2, 49-57 (1934)。 
Heckler, 0., Hofmann, W., and Hanemann, H., "The Aging and. Endurance Strength of Lead-Calcium Alloys," Z. Metallkunde, 30, 419-22 (1938).

Hofmann, W., Lead and Lead Allovs Properties and Technology, 44-50, Springer-Verlag, New York (1970).

Lyashenko, V. S., "Aging of Lead Alloys Containing Antimony, Calcium and Barium," Metallurg, 13, 12, 99-1.13 (1938).

Mantell, C. L., and Hardy, C., Calcium Metallurgy and Technology, 66-94, Reinhold Publishing Corporation, New York (1945).

Mantell, C.L., and Hardy, C., "Engineering Alloys Containing Calcium," Metals and Alloys, 19, 2, 364-367 (1944). 
APPENDIXES 
APPENDIX A

\section{HARDNESS CONVERSION}

The Brinell hardness number (BHN) is expressed as a load $P$ divided by the surface area of the indentation. This is expressed by the formula

$$
B H N=\frac{P}{\left(\pi \frac{D}{2}\right)\left(\dot{D}-\sqrt{D^{2}-d^{2}}\right)}
$$

where $P=$ applied load, $\mathrm{kg} ; D=$ diameter of penetrator, $\mathrm{mm}$; and $\mathrm{d}=$ diameter of indentation, $\mathrm{mm}$.

The Rockwell hardness test utillzes the depth or indentalion, under constant load; as a measure of hardness. Each divislon on the Rockwell dial represents an indentation of $0.002 \mathrm{~mm}$. The depth of indentation is related to the diameter of the penetrator and diameter of the indentation by

$$
d=\sqrt{4 h(D-h)}
$$

where $h=$ depth of indentation, $\mathrm{mm}$.

Therefore, the Brinell hardness number is related to load, dialileter of penetration and depth of indentation by

$$
B H N=\frac{p}{\left(\pi \frac{D}{2}\right)\left(D-\sqrt{D^{2}-4 h(D-h)}\right)}
$$

The Brinell hardness number as a function of depth of indentation, when plotted on a logmluy scale, is a straight line as illustrated in Figure $A-1$. 


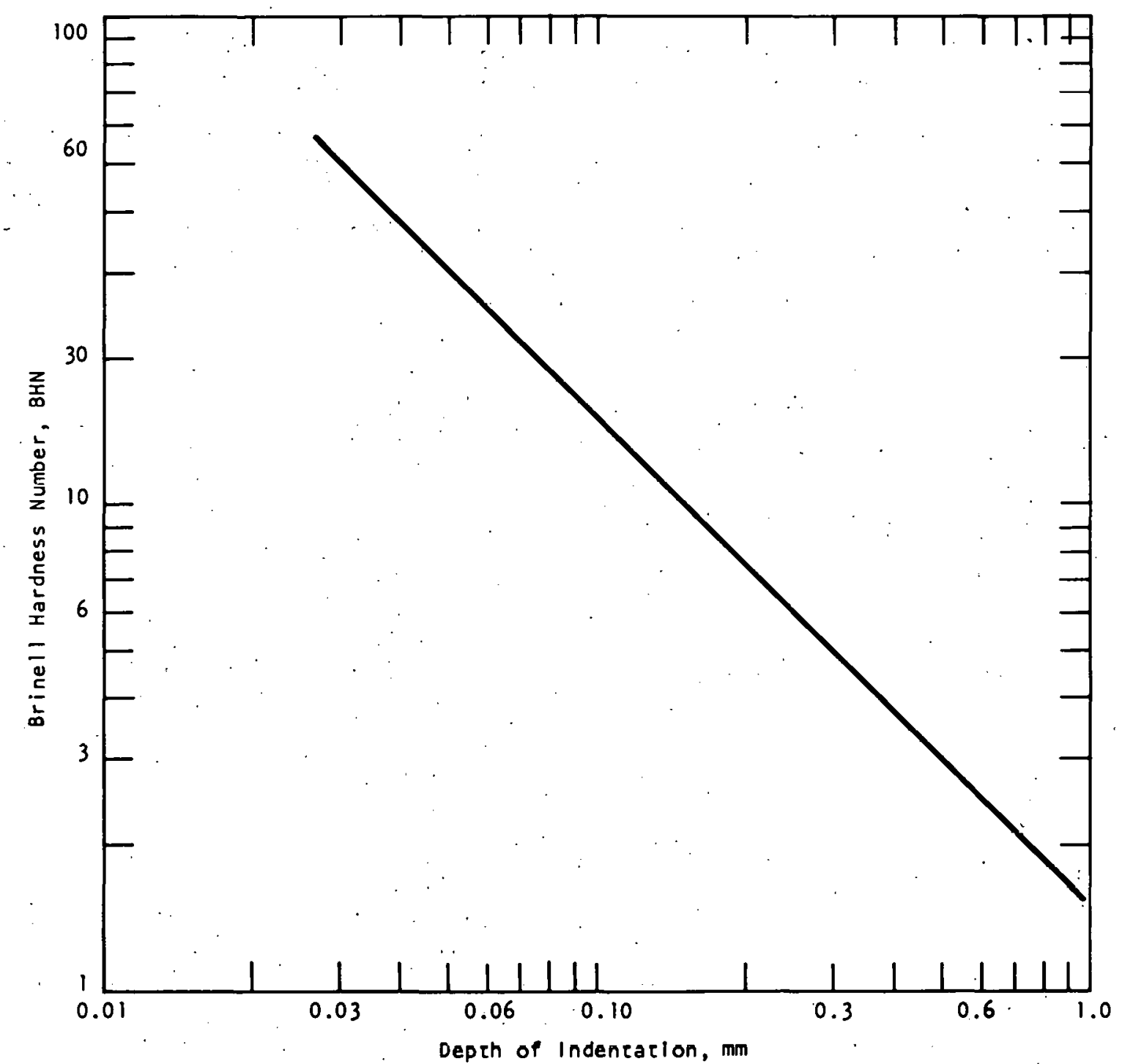

Figure A-1. The Brinell hardness number as a function of depth of indentation for a 1/2-inch penetrator and a $60 \mathrm{~kg}$ load. 
APPENDIX. B

CALCIUM CONTENT IN BASE METAL COUPONS

TABLE B-1

CALCIUM CONTENT OF BASE METAL COUPONS USED FOR HARDNESS AND TENSILE STRENGTH EVALUATION, WEIGHT PERCENT

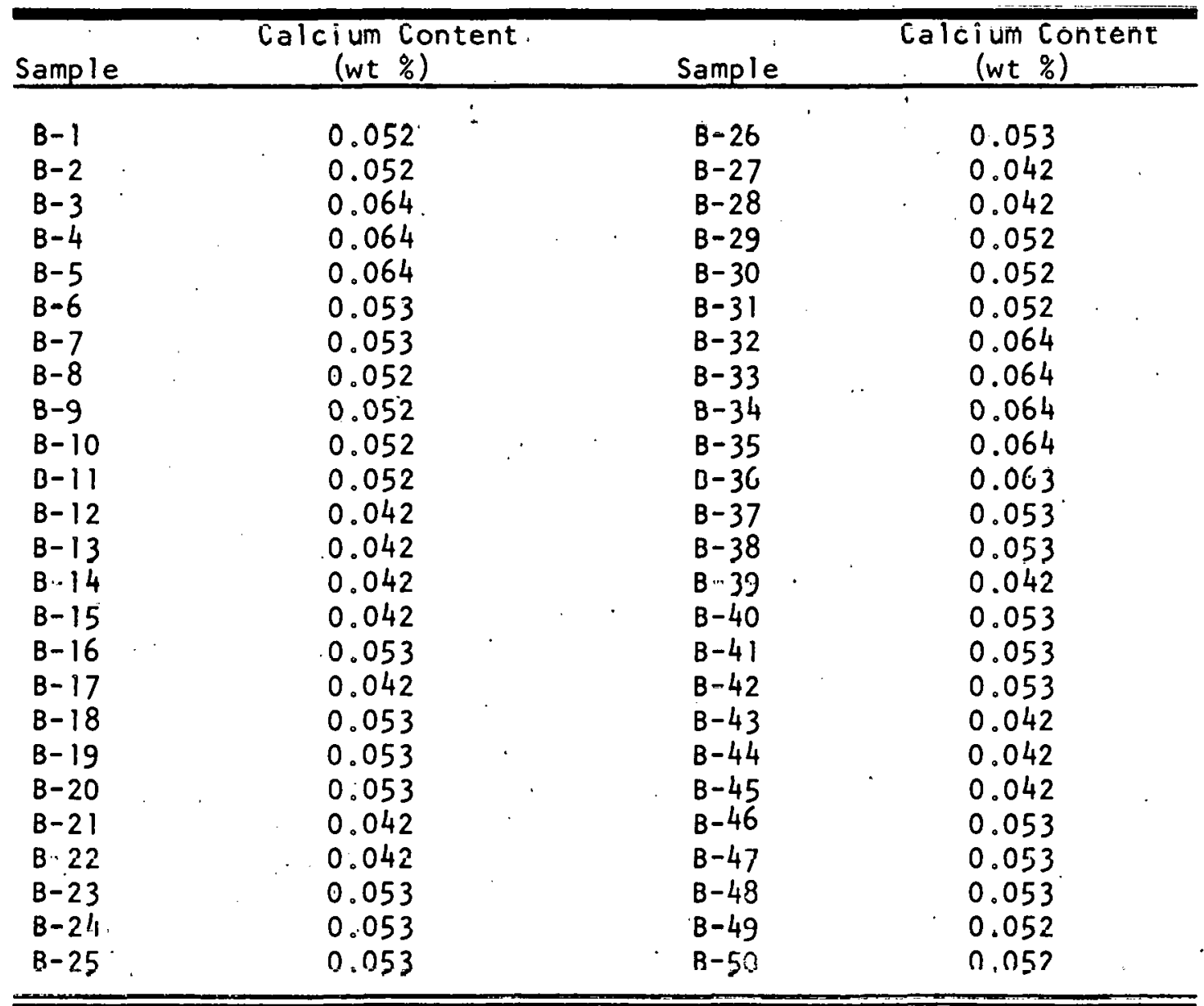


APPENDIX C

HARDNESS DATA

TABLE C -1

HARDNESS AT VARIOUS AGING TIMES FOR BASE METAL SAMPLES SOLUTION HEAT TREATED AT $300^{\circ} \mathrm{C}$ FOR THE TIMES INDICATED, WATER QUENCHED ANO ROOM TEMPERATURE AGED

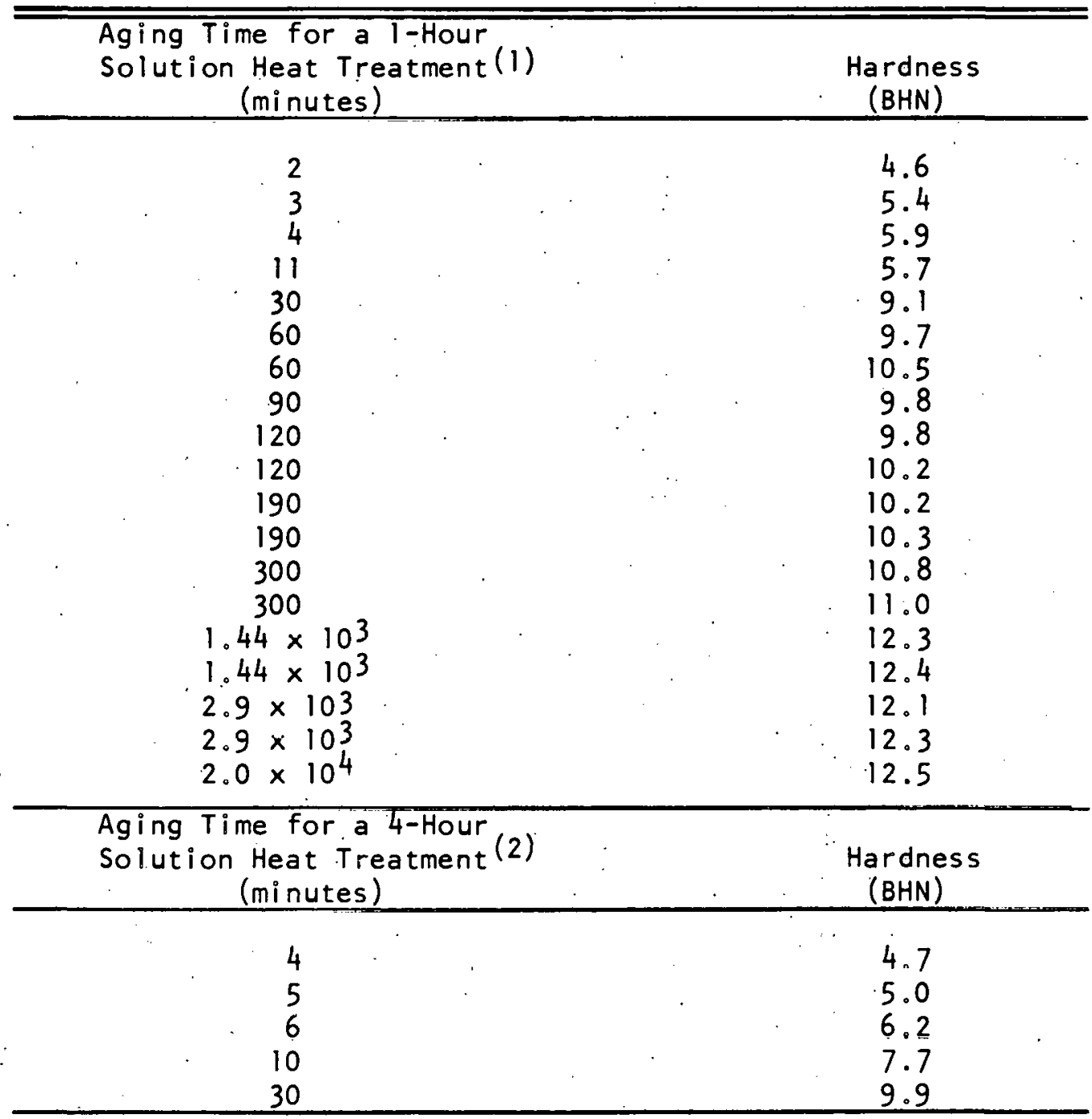


80

TABLE C -1 (continued)

\begin{tabular}{|c|c|c|c|}
\hline $\begin{array}{l}\text { Aging Time-for a } 4 \text {-Hour } \\
\text { Solution Heat Treatment }(2) \\
\text { (minutes) }\end{array}$ & & & $\begin{array}{l}\text { Hardness } \\
(\mathrm{BHN})\end{array}$ \\
\hline $\begin{array}{c}30 \\
60 \\
60 \\
90 \\
90 \\
120 \\
120 \\
180 \\
180 \\
270 \\
270 \\
1.44 \times 10^{3} \\
1.44 \times 10^{3} \\
2.9 \times 10^{3} \\
2.9 \times 10^{3} \\
2.0 \times 10^{4} \\
2.0 \times 10^{4}\end{array}$ & & & $\begin{array}{l}9.8 \\
10.3 \\
10.5 \\
10.7 \\
10.7 \\
10.7 \\
10.5 \\
11.0 \\
11.3 \\
11.0 \\
11.5 \\
13.7 \\
13.5 \\
13.5 \\
13.5 \\
13.2 \\
13.7\end{array}$ \\
\hline $\begin{array}{c}\text { Aging Time for a } 16 \text {-Hour } \\
\text { Solution Heat Treatment }(3) \\
\text { (minutes) }\end{array}$ & & & $\begin{array}{l}\text { Hardness } \\
\text { (BHN) }\end{array}$ \\
\hline $\begin{array}{r}5 \\
6 \\
7 \\
10 \\
10 \\
30 \\
30 \\
60 \\
60 \\
20 \\
90 \\
120 \\
120 \\
180 \\
180 \\
300 \\
300 \\
1.44 \times 103 \\
1.44 \times 10^{3}\end{array}$ & . & . & $\begin{array}{l}5.5 \\
5.6 \\
5.9 \\
9.0 \\
8.6 \\
9.9 \\
9.8 \\
10.2 \\
10.0 \\
10.3 \\
10.3 \\
10.8 \\
10.7 \\
10.7 \\
11.0 \\
11.3 \\
11.3 \\
12.5 \\
12.3\end{array}$ \\
\hline
\end{tabular}


TABLE C-1 (continued)

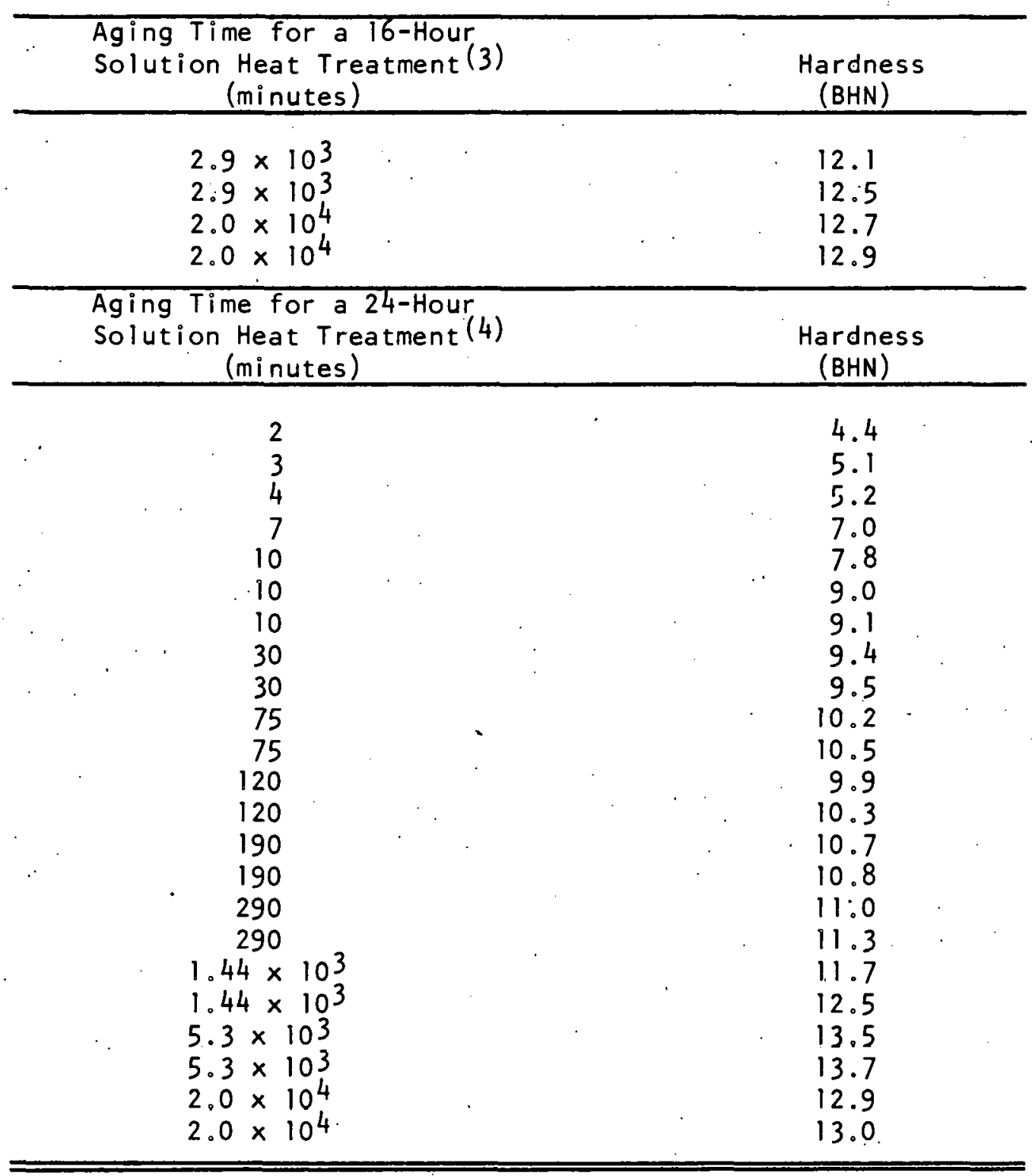
(1) Sample B-1
(2) Sample B-2
(3) Saniple B-3
(4) Sample B-4 
TABLE $C-2$

HARDNESS AT VARIOUS AGING TIMES FOR BASE METAL SAMPLES SOLUTION

HEAT TREATED AT $300^{\circ} \mathrm{C}$ FOR TWO HOURS, WATER QUENCHED, AGED AT $100^{\circ} \mathrm{C}$ FOR THE TIMES INDICATED AND

FOLLOWED BY A ROOM TEMPERATURE AGE

3

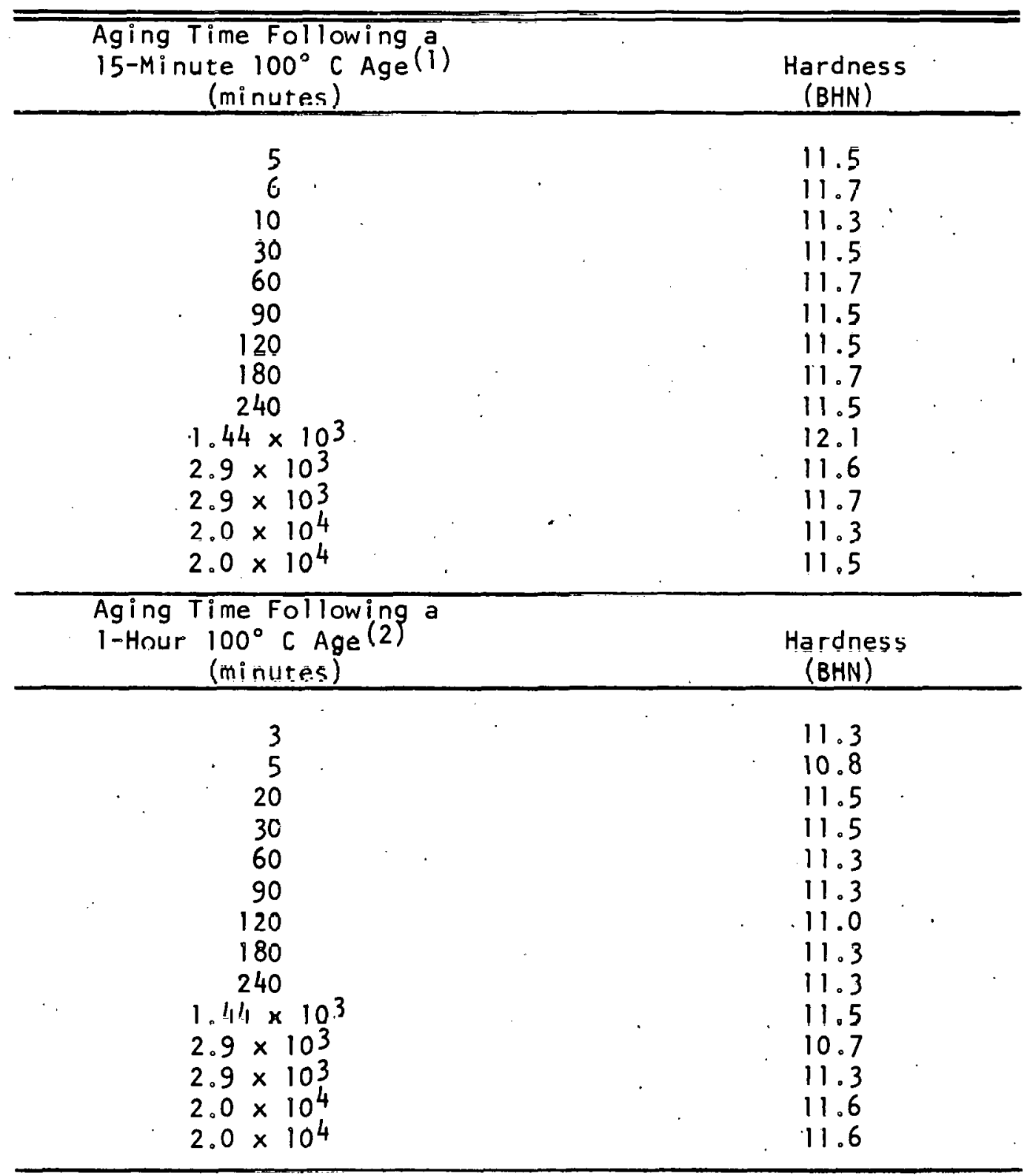


TABLE C-2 (continued)

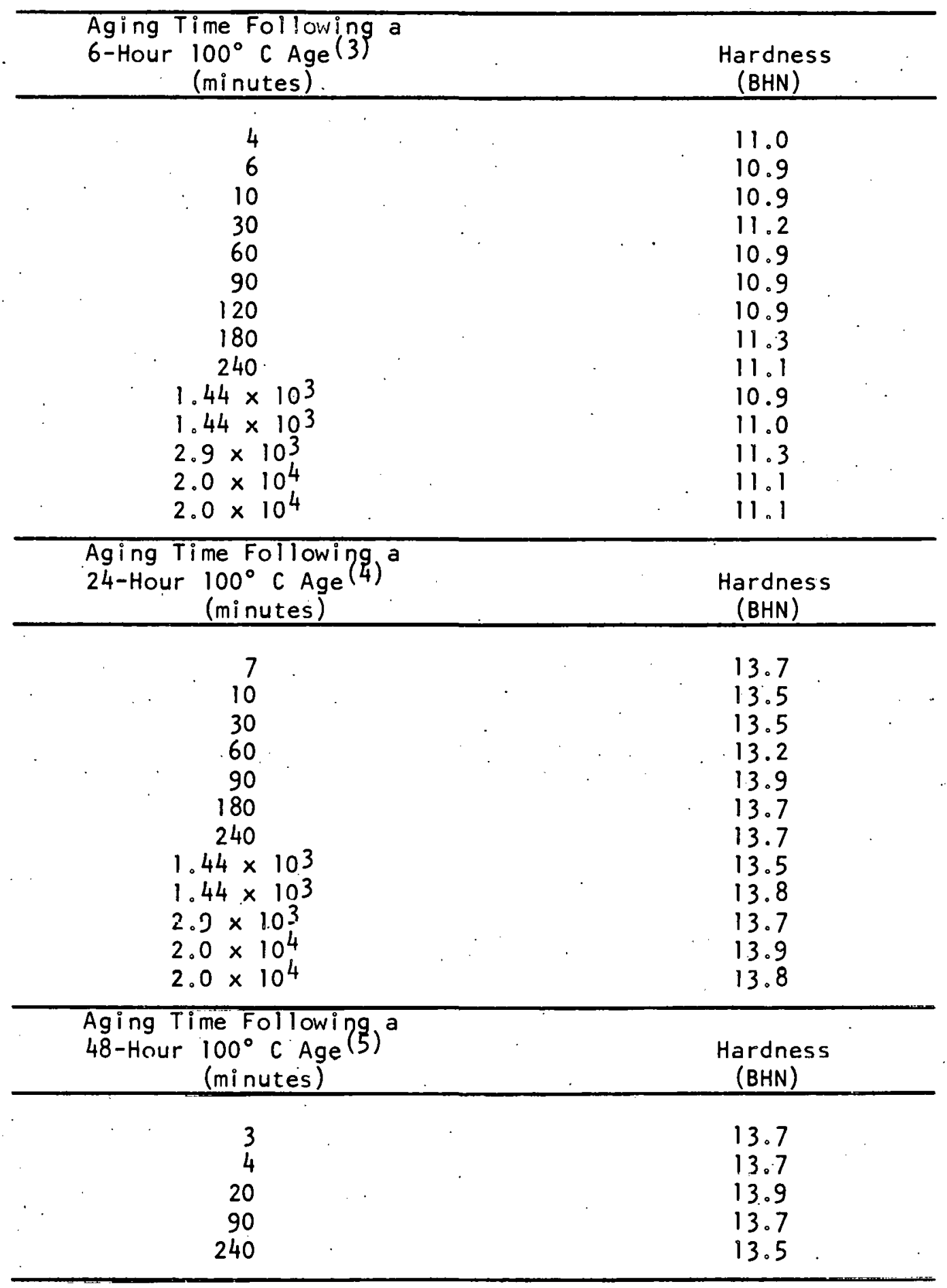


TABLE C-2 (continued)

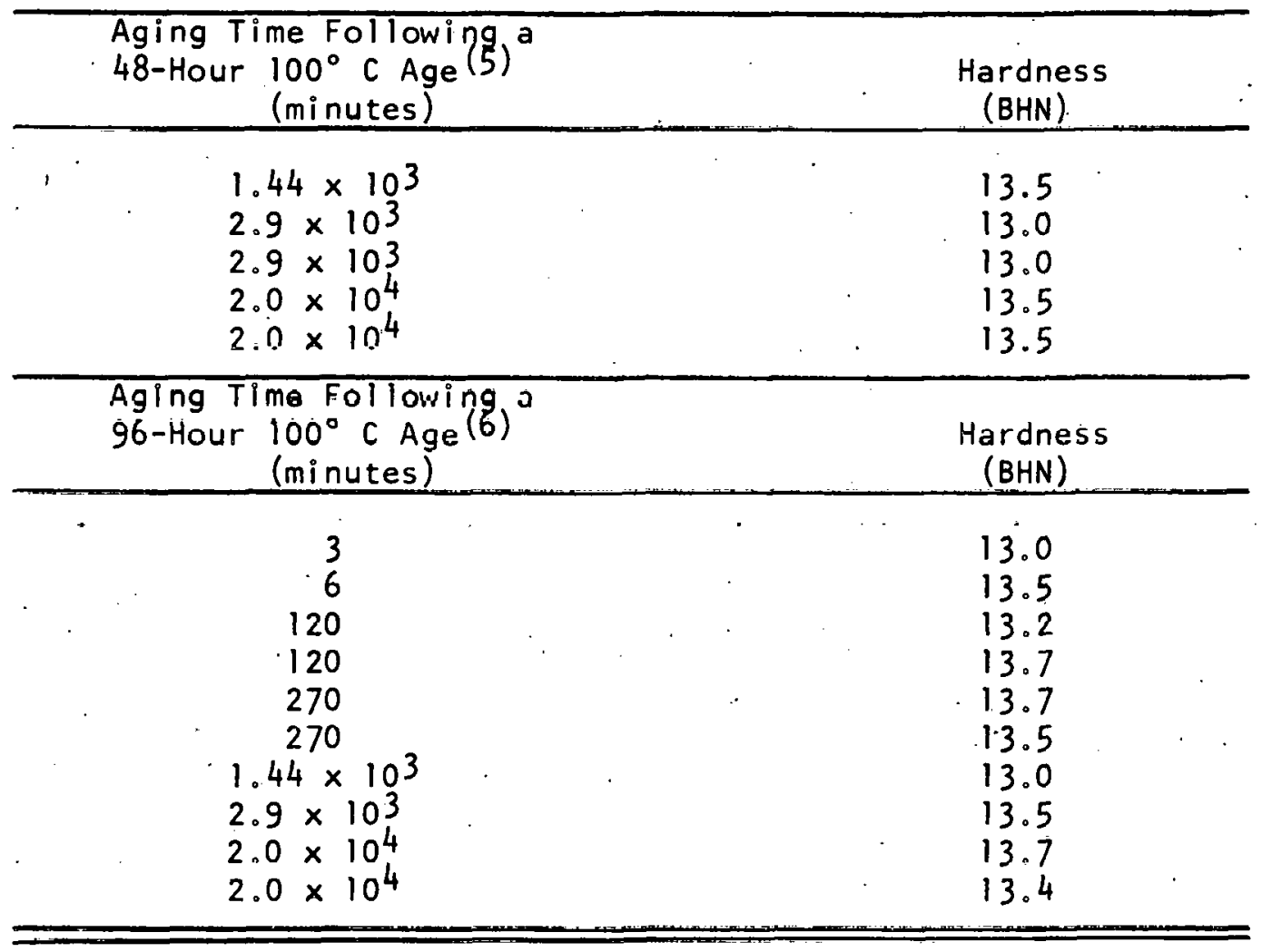

(1) Sample B-5

(2) Sample B-6

(3) Sample B-7

(4) Sample B-8

(5) Sample B-9

(6) Sample B-10 
TABLE $C-3$
HARDNESS AT VARIOUS AGING TIMES FOR WELD METAL SAMPLES SOLUTION HEAT TREATED AT $300^{\circ} \mathrm{C}$ FOR THE TIMES INDICATED, WATER QUENCHED AND ROOM TEMPERATURE AGED

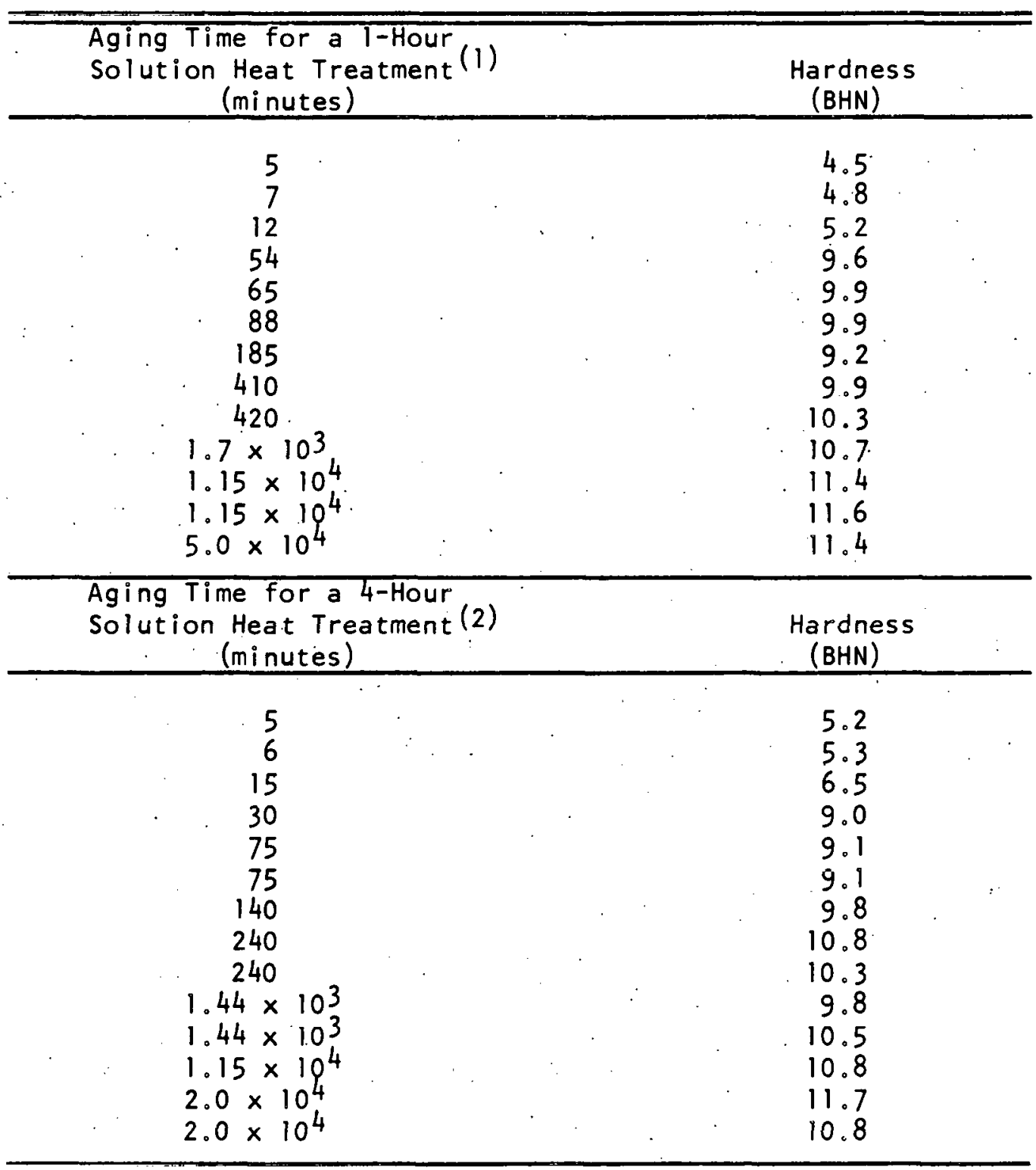


TABLE C-3 (continued)

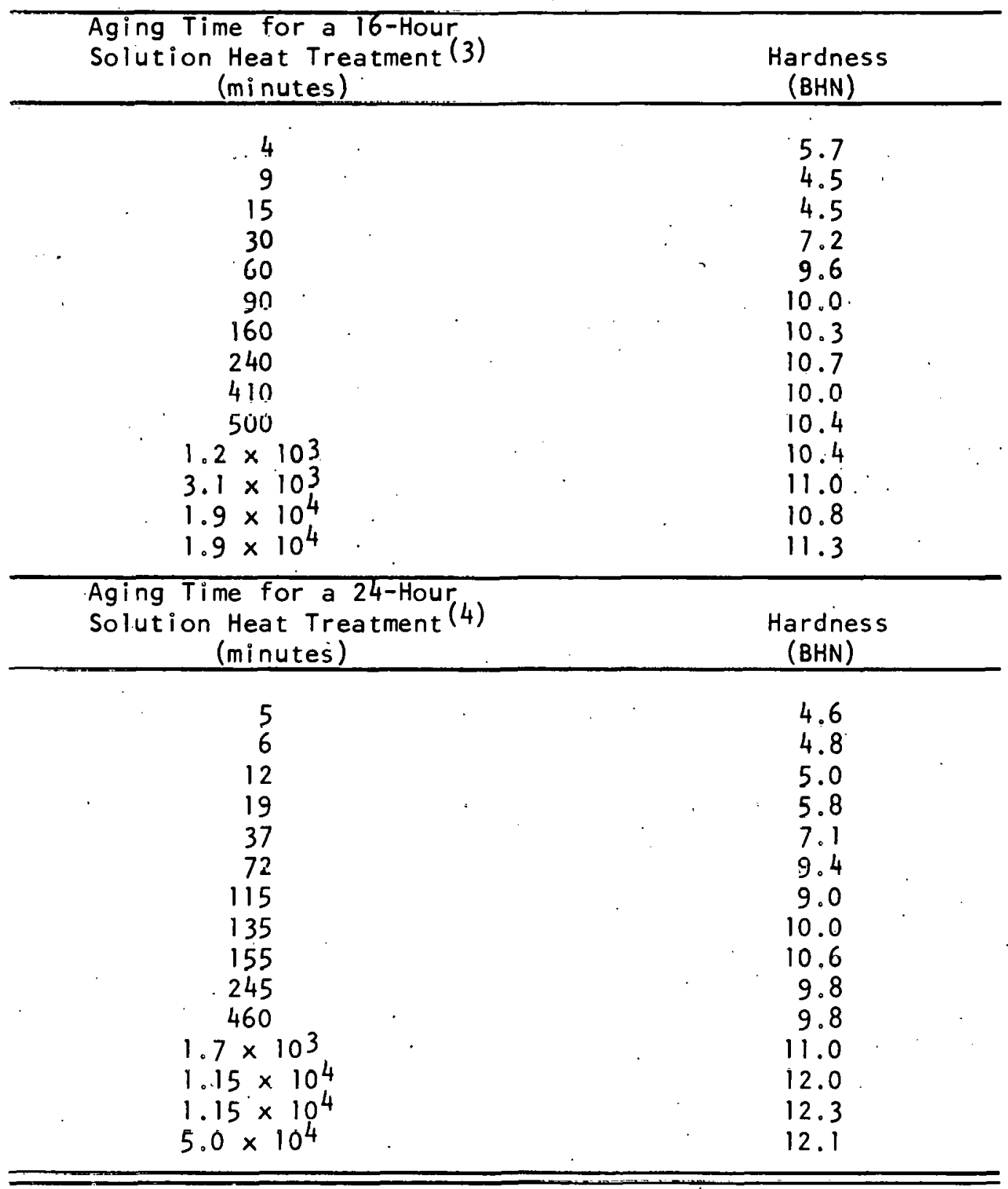
(1) Sample $W-10$
(2) Sample W-11
(3) Sample W-2
(4) Sample $W-12$ 


\section{7}

TABLE $C-4$

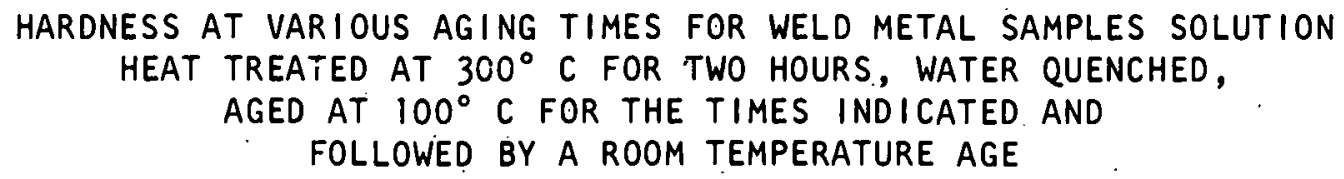

\begin{tabular}{|c|c|}
\hline $\begin{array}{c}\text { Aging Time Following } \\
1 / 2-\text { Hour } 100^{\circ} \mathrm{C} \cdot \mathrm{Age}^{(1)} \\
\text { (minutes) } \\
\end{array}$ & $\begin{array}{c}\text { Hardness } \\
\text { (BHN) }\end{array}$ \\
\hline $\begin{array}{r}5 \\
6 \\
9 \\
36 \\
50 \\
110 \\
220 \\
330 \\
1.3 \times 10^{3} \\
3.0 \times 10^{3} \\
1.3 \times 10^{4} \\
2.0 \times 10^{4}\end{array}$ & $\begin{array}{r}8.9 \\
9.3 \\
9.4 \\
9.7 \\
9.5 \\
10.0 \\
9.9 \\
9.9 \\
9.8 \\
10.0 \\
8.9 \\
10.0\end{array}$ \\
\hline $\begin{array}{c}\text { Aging Time Following } \\
\text { a } 1 \text {-Hour } 100^{\circ} \mathrm{C} \text { Age } \\
\text { (minutes) }\end{array}$ & $\begin{array}{c}\text { Hardness } \\
(\mathrm{BHN})\end{array}$ \\
\hline $\begin{array}{r}3 \\
5 \\
6 \\
9 \\
20 \\
80 \\
200 \\
200 \\
300 \\
300 \\
1.3 \times 10^{3} 3 \\
3.0 \times 10^{3} \\
1.3 \times 10^{4} \\
2.0 \times 10^{4}\end{array}$ & $\begin{array}{r}9.2 \\
10.0 \\
10.3 \\
10.0 \\
10.4 \\
10.0 \\
9.3 \\
9.6 \\
8.9 \\
9.4 \\
9.6 \\
9.4 \\
9.9 \\
10.2\end{array}$ \\
\hline
\end{tabular}


TABLE C-4 (continued)

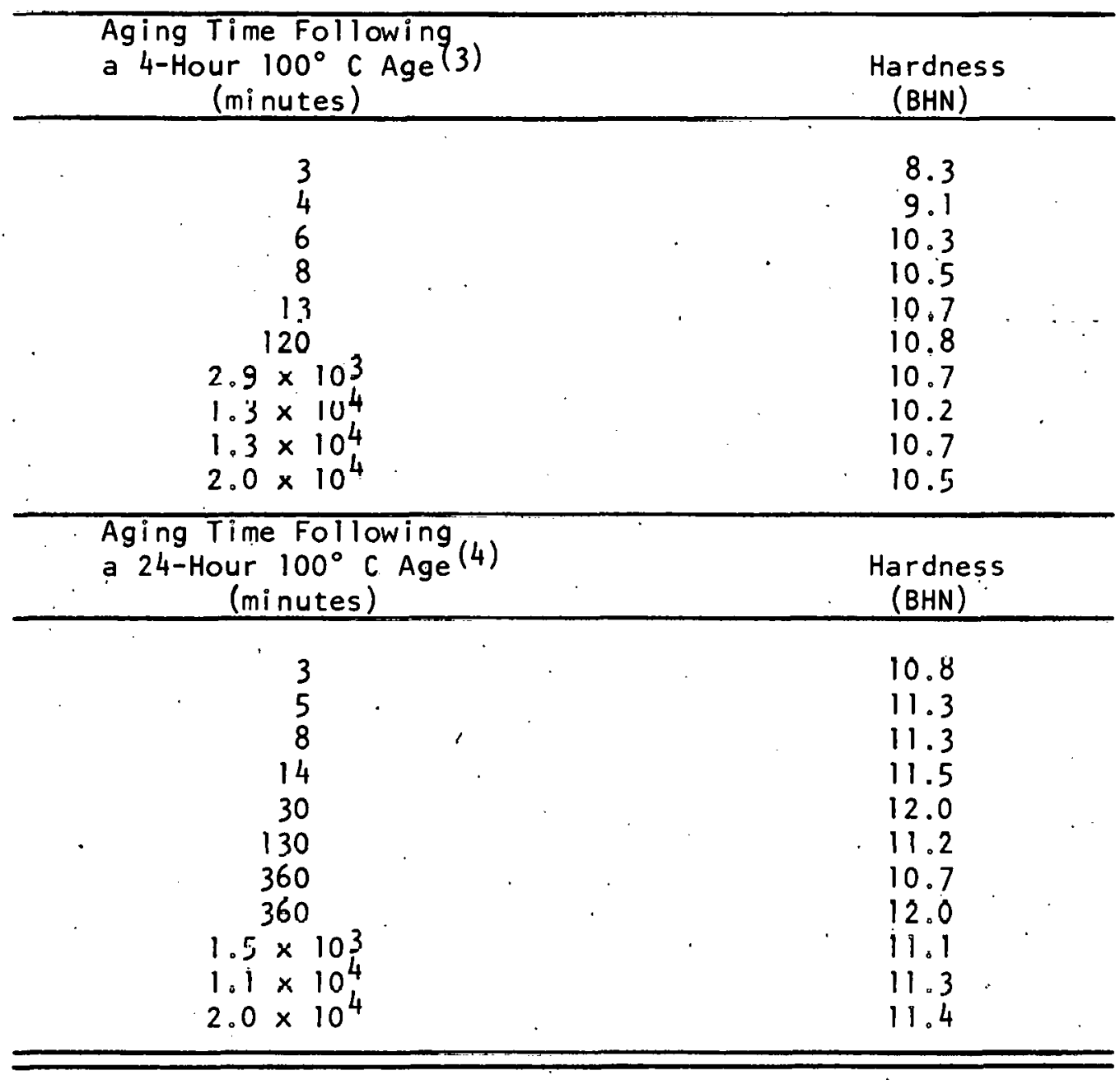

(1) Sample $W-4$

(2) Sample $W-5$

(3) Sample $W-6$

(4) Sample $W-\%$ 
TABLE. C -5

HARDNESS AT VARIOUS AGING TIMES, FOR WELD METAL SAMPLES IN THE AS-WELDED AND ROOM TEMPERATURE AGED CONDITION(1)

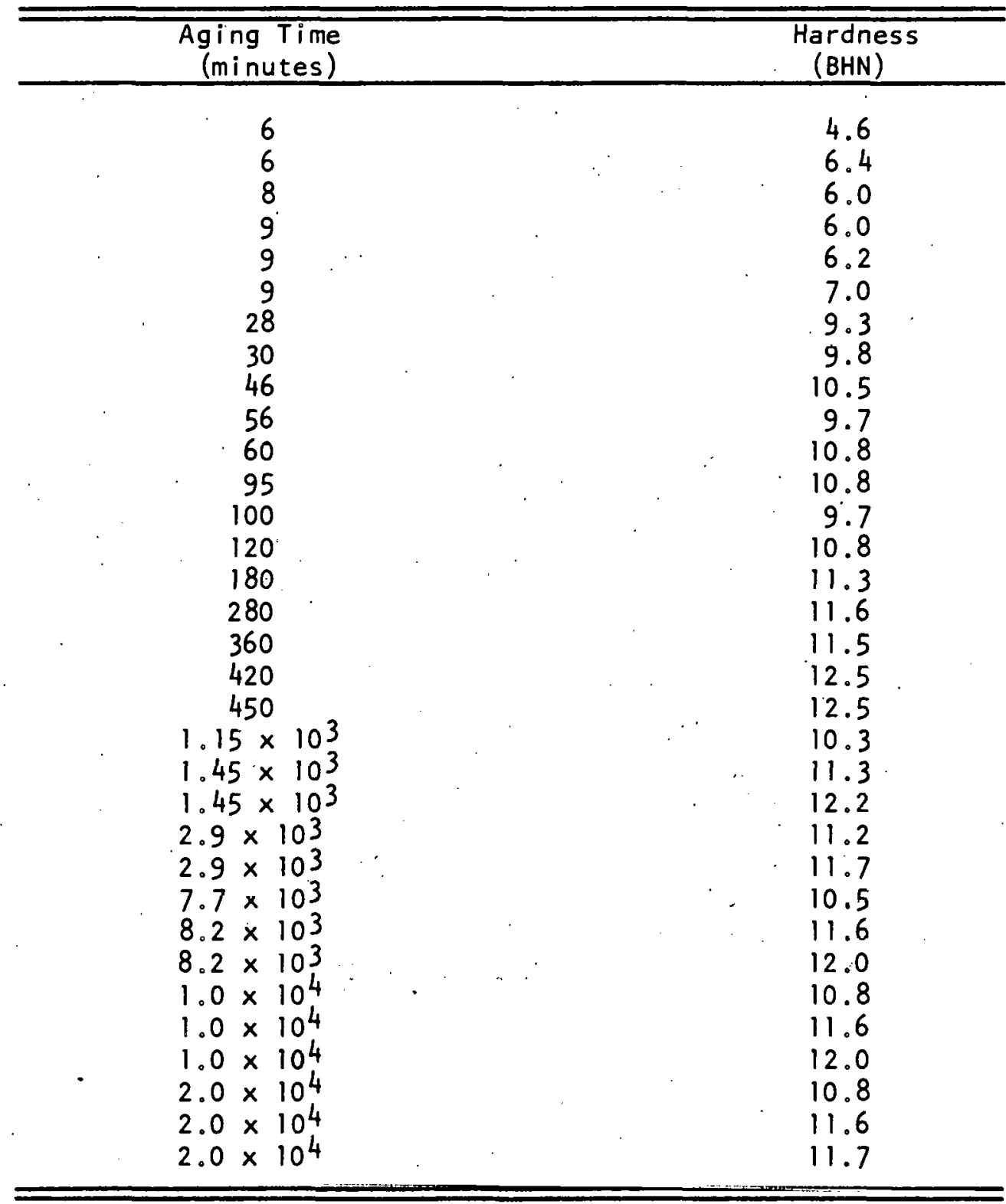

(1) Sample $W-52$ and $W-54$ 
TABLE C -6

HARDNESS, TRAVERSE IN AN INITIALLY FULLY HARDENED BASE METAL

IN THE AS-WELDED CONDITION, TWO WEEKS AFTER WELDING $(1)$

\begin{tabular}{cc}
\hline \hline $\begin{array}{c}\text { Distance from Initial } \\
\text { Indent in Base Metal } \\
\text { (inches) }\end{array}$ & $\begin{array}{c}\text { Hardness } \\
\text { (DPH) }\end{array}$ \\
\hline 0.000 & 14.9 \\
0.035 & 16.0 \\
0.070 & 16.0 \\
0.105 & 15.4 \\
0.110 & 15.4 \\
0.175 & 16.4 \\
0.210 & 16.8 \\
0.245 & 17.9 \\
0.280 & 16.8 \\
0.315 & 18.2 \\
0.330 & 18.7 \\
0.345 & 18.7 \\
0.360 & 15.9 \\
0.375 & 18.4 \\
0.390 & 20.0 \\
0.405 & 16.4 \\
0.420 & 16.4 \\
0.435 & 16.6 \\
0.450 & 16.0 \\
0.465 & 15.7 \\
0.480 & 14.9 \\
0.495 & 15.2 \\
0.510 & 17.0 \\
0.525 & 17.0 \\
0.540 & 15.9 \\
\hline
\end{tabular}

(1) Santip le $w-53$ 


\section{APPENDIX D}

TENSILE DATA

TABLE $D-1$

TENSILE STRENGTH AT VARIOUS AGING TIMES FOR BASE METAL SAMPLES SOLUTION HEAT TREATED AT $300^{\circ}$ C FOR TWO HOURS, WATER QUENCHED AND ROOM TEMPERATURE AGED

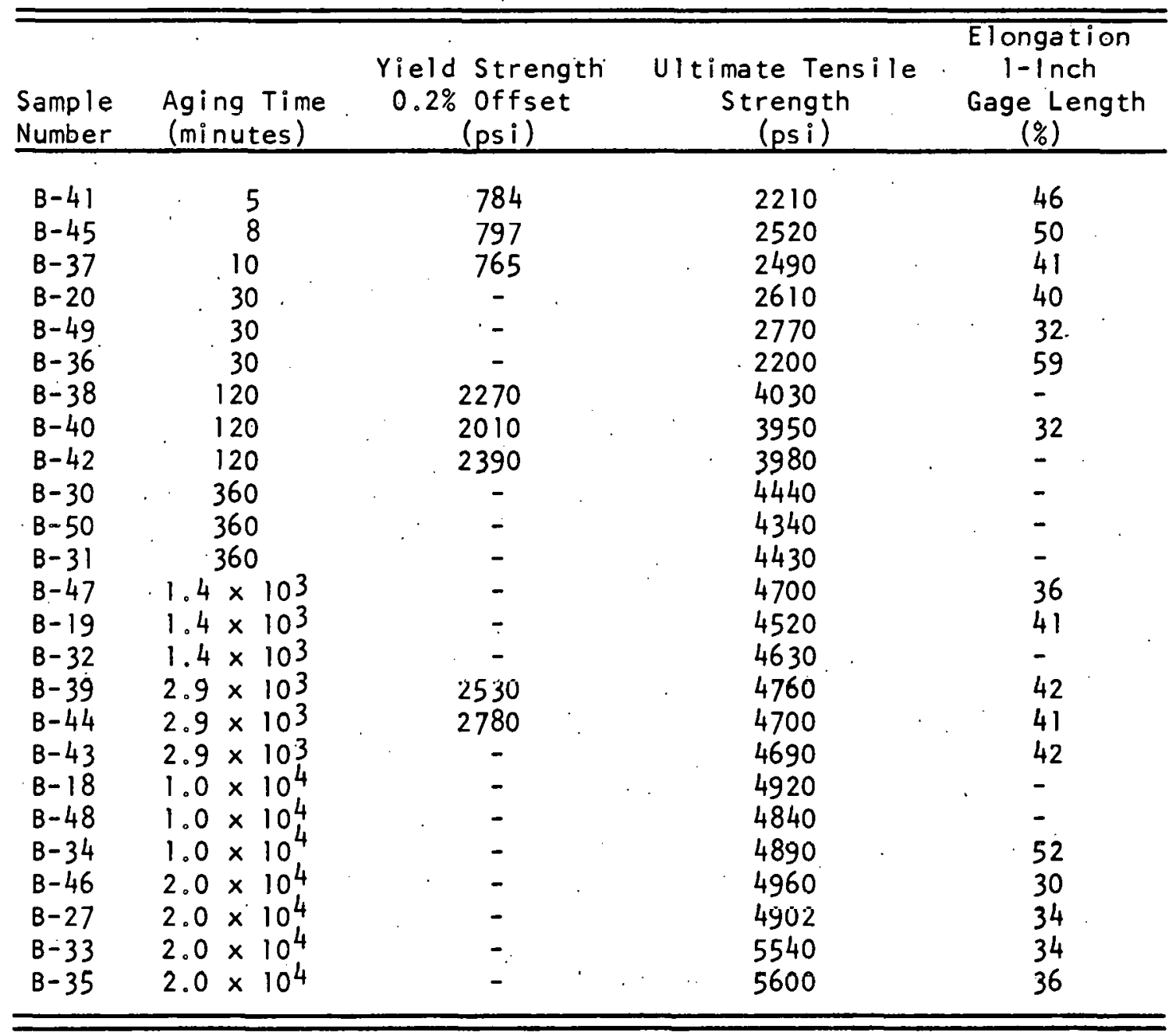


TABLE D-2

TENSILE STRENGTH AT VARIOUS AGING TIMES FOR BASE METAL SAMPLES SOLUTION HEAT TREATED AT $300^{\circ} \mathrm{C}$ FOR TWO HOURS, WATER QUENCHED AND AGED AT $100^{\circ} \mathrm{C}$

\begin{tabular}{lccc}
\hline \hline Sample & $\begin{array}{c}\text { Aging Time } \\
\text { (minutes) }\end{array}$ & $\begin{array}{c}\text { U1timate Tensile } \\
\text { Strength } \\
(\text { psi) }\end{array}$ & $\begin{array}{c}\text { Elongation } \\
\text { I-Inch } \\
\text { Gage Length } \\
(\%)\end{array}$ \\
\hline$B-15$ & 30 & 4060 & 57 \\
$B-22$ & 30 & 4110 & 37 \\
$B-12$ & 30 & 4060 & 25 \\
$B-14$ & 60 & 4170 & 50 \\
$B-17$ & 60 & 4110 & 42 \\
$B-13$ & 60 & 4140 & 39 \\
$B-11$ & 240 & 4280 & 30 \\
$B-28$ & 240 & 4230 & 39 \\
$B-21$ & 240 & 4330 & - \\
$B-16$ & $1.4 \times 103$ & 4320 & 46 \\
$B-23$ & $1.4 \times 103$ & 4320 & - \\
$B-25$ & $1.4 \times 103$ & 4510 & 38 \\
$B-24$ & $2.8 \times 103$ & 4500 & 39 \\
$B-26$ & $2.8 \times 103$ & 4610 & \\
$B-29$ & $2.8 \times 103$ & 4620 & \\
\hline \hline
\end{tabular}


TABLE D-3

TENSILE STRENGTH AT VARIOUS AGING TIMES FOR LONGITUDINAL-WELD METAL SAMPLES SOLUTION HEAT TREATED AT $300^{\circ} \mathrm{C}$ FOR TWO HOURS, WATER QUENCHED AND ROOM TEMPERATURE AGED

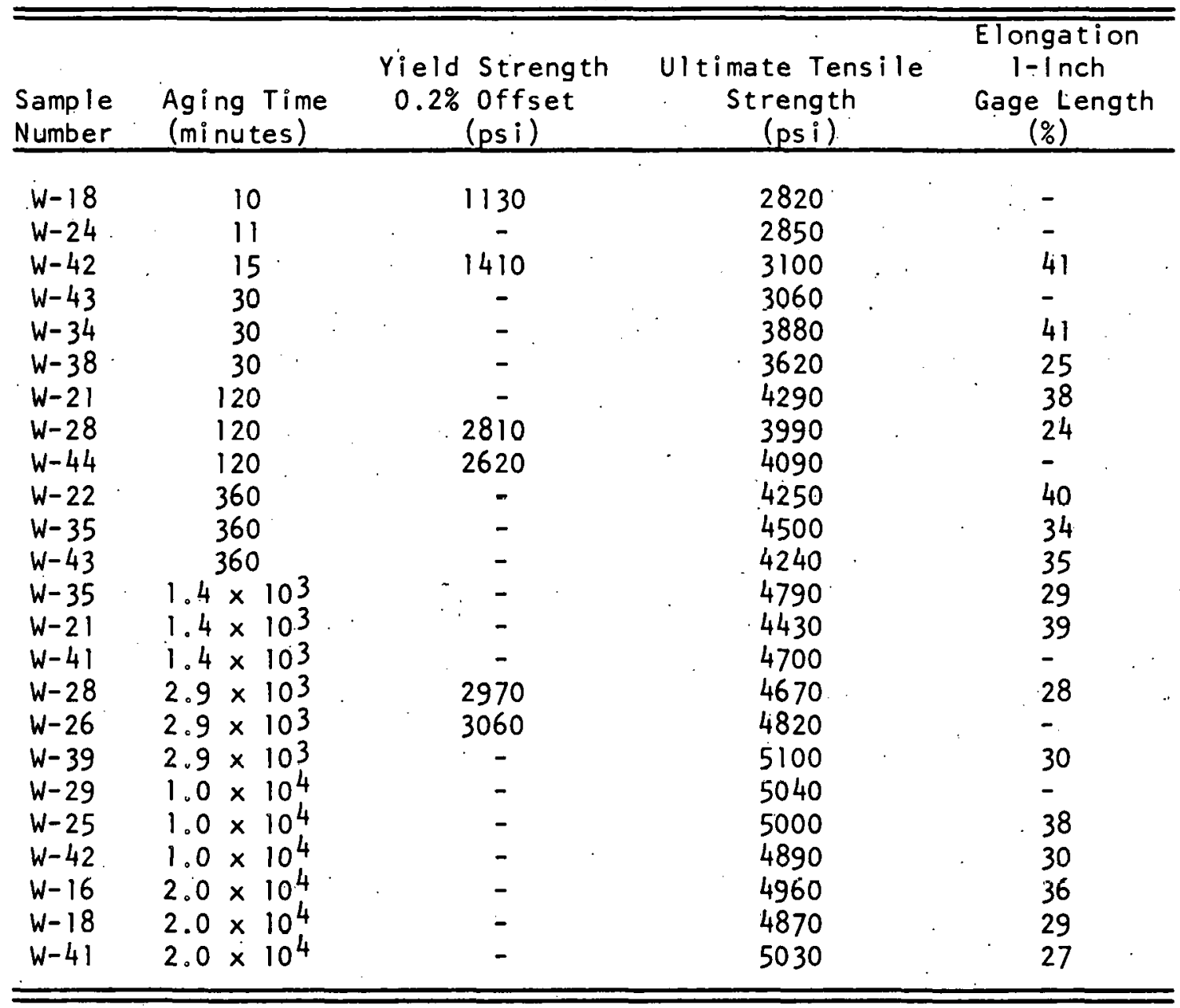


TABLE $D-4$

TENSILE STRENGTH AT VARIOUS AGING TIMES FOR LONGITUDINAL-WELD METAL SAMPLES SOLUTION HEAT TREATED AT $300^{\circ} \mathrm{C}$ FOR TWO HOURS, WATER QUENCHED AND AGED AT $100^{\circ} \mathrm{C}$

\begin{tabular}{|c|c|c|c|}
\hline $\begin{array}{l}\text { Sample } \\
\text { Numimber } \\
\end{array}$ & $\begin{array}{l}\text { Aging Time } \\
\text { (minutes) }\end{array}$ & $\begin{array}{c}\text { Ultimate Tensile } \\
\text { Strength } \\
\text { (psi) }\end{array}$ & $\begin{array}{c}\text { Elongation } \\
\text { I-Inch } \\
\text { Gage Length } \\
(\%)\end{array}$ \\
\hline$W=23$ & 30 & 3990 & - \\
\hline$w-17$ & 30 & 3930 & 52 \\
\hline$W-40$ & 30 & 11050 & 22 \\
\hline$w-33$ & 60 & 4560 & - \\
\hline$w-33$ & 60 & 4400 & 34 \\
\hline$w-19$ & 60 & 4490 & 45 \\
\hline$W-22$ & 240 & 4310 & 30 \\
\hline$W-25$ & 240 & 4220 & 13 \\
\hline$W-38$ & 240 & 4520 & 45 \\
\hline$W-30$ & $1.4 \times 103$ & 4.420 & 36 \\
\hline$W-32$ & $1.4 \times 103$ & 4810 & 34 \\
\hline$W-18$ & $1.4 \times 10^{3}$ & 4630 & 30 \\
\hline$w-19$ & $2.8 \times 103$ & 4510 & - \\
\hline$W-30$ & $2.8 \times 10^{3}$ & 4770 & 34 \\
\hline$W-34$ & $2.8 \times 10^{3}$ & 4760 & - \\
\hline
\end{tabular}


TABLE D -5

TENSILE STRENGTH AT VARIOUS AGING TIMES FOR TRANSVERSE-WELD METAL SAMPLES SOLUTION HEAT TREATED AT. $300^{\circ} \mathrm{C}$ FOR TWO HOURS, WATER QUENCHED AND ROOM TEMPERATURE AGED

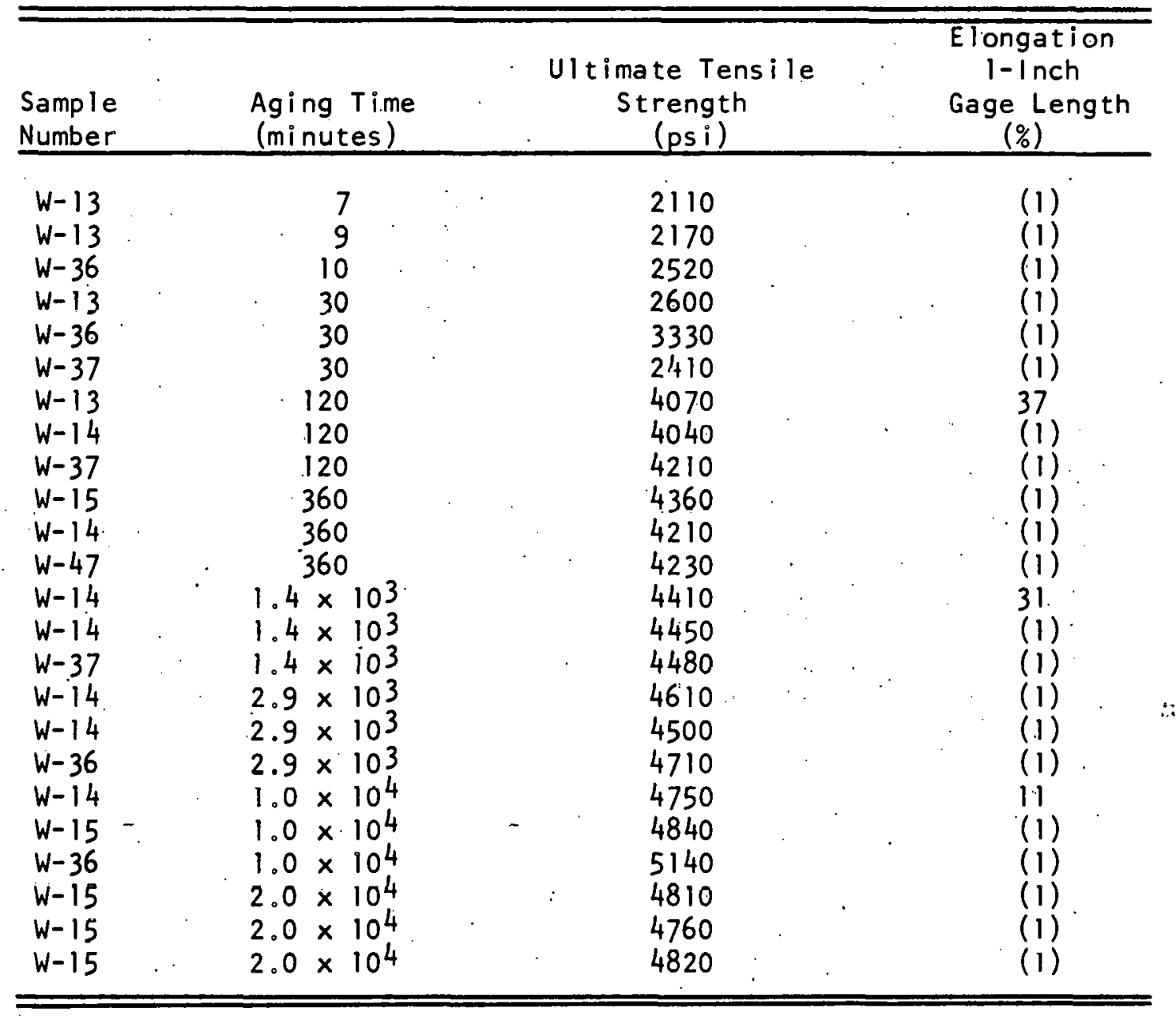

(1) Failed in the heat-affected zone 
TABLE $D-6$

TENSILE STRENGTH AT VARIOUS AGING TIMES FOR TRANSVERSE-WELD

METAL SAMPLES SOLUTION HEAT TREATED AT $300^{\circ} \mathrm{C}$ FOR TWO

HOURS, WATER QUENCHED AND AGED AT $100^{\circ} \mathrm{C}$

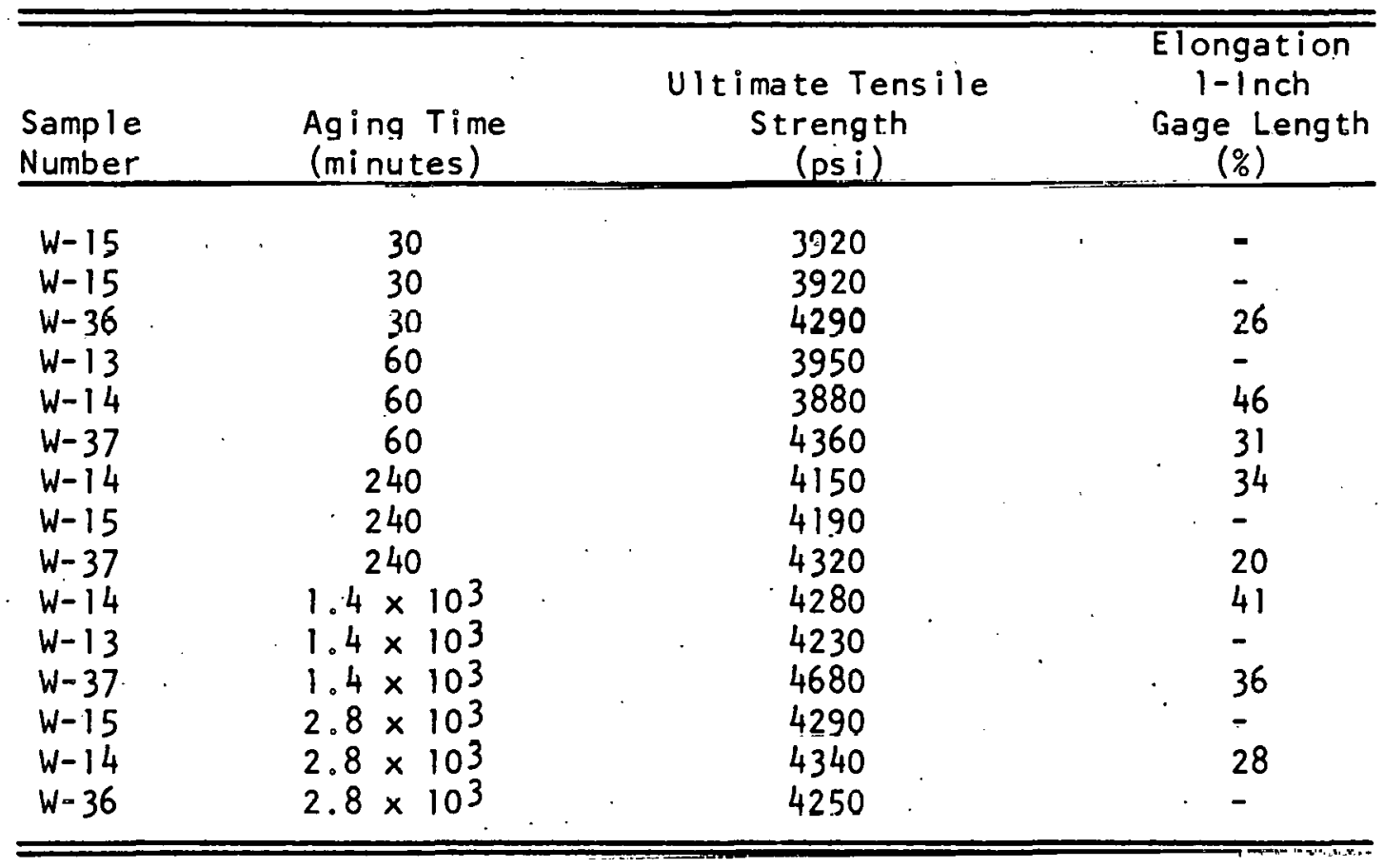


TABLE $D-7$

TENSILE STRENGTH AT VARIOUS AGING TIMES FOR WELDED SAMPLES

IN THE AS-WELDED AND ROOM TEMPERATURE AGED CONDITION

\begin{tabular}{|c|c|c|c|}
\hline $\begin{array}{l}\text { Sample } \\
\text { Number }\end{array}$ & $\begin{array}{l}\text { Aging Time } \\
\text { (minutes) }\end{array}$ & $\begin{array}{c}\text { Ultimate Tensile } \\
\text { Strength } \\
\text { (psi) }\end{array}$ & $\begin{array}{l}\text { Elongation } \\
1-\text { Inch } \\
\text { Gage Length } \\
(\%)\end{array}$ \\
\hline \multicolumn{4}{|c|}{ Longitudinal-Weld Samples } \\
\hline $\begin{array}{l}W-46 \\
W-46 \\
W-44\end{array}$ & $\begin{array}{l}2.8 \times 10^{4} \\
2.8 \times 10^{4} \\
2.8 \times 10^{4}\end{array}$ & $\begin{array}{r}5338 \\
5255 \\
5390\end{array}$ & $\begin{array}{l}- \\
23 \\
21\end{array}$ \\
\hline \multicolumn{4}{|c|}{ Transverse-Weld Samples } \\
\hline $\begin{array}{l}w-47 \\
W-47 \\
W-47\end{array}$ & $\begin{array}{l}2.8 \times 10^{4} \\
2.8 \times 10^{4} \\
2.8 \times 10^{4}\end{array}$ & $\begin{array}{l}4677 \\
4585 \\
4576\end{array}$ & $\begin{array}{l}\text { (1) } \\
(1) \\
(1)\end{array}$ \\
\hline
\end{tabular}

(1) Failed in the heat-affected zone 
Walter Wayne Canary

He attended elementary school in Grove $C i t y$ and Columbus and was graduated from Grove City High School in 1963. The following September he entered Ohio State University, and in June 1968, he received a Bachelor of Science degree in Welding Engineering. Immediately thereafter, he accepted employment with the Union Carbide Corporation-Nuclear Division ot the $Y-12$ Plant in Oak Ridue. Tennessee. Simultanenusly, he began part-time graduate studies at The University of Tennessee. 
DISTRIBUTION

Atomic Energy Commission-0RO

Hickman, H. D.

Zachry, D. S., Jr

Dow-Rocky Flats

Palan, R. C.

Lawrence Livermore Laboratory

Armstrong, R. E.

Mara, G. A.

Roberts, L. W.

Weiss, H.

Jones, F. W.

Kahl, K. G.

Keith, Alvin

Kite, H. T.

Mitchel, G. W.

Moisson, W. C.

Schreyer, J. M.

Smith, H. F., Jr

Smith, J. H.

Smith, R. D.

Stoner, H. H.

Tench, F. M.

Tilson, F. V.

Townsend, A. B.

Los Alamos Scientific Laboratory

Turner, P. W. (3)

Wilkinson, P. E.

Hanks, G. S.

Williams, R. D.

Yaggi, W. J.

Oak. Ridge Gaseous Diffusion Plant

$Y-12$ Central Files (5)

$Y-12$ Central Files (master copy)

$Y-12$ Central Files (route)

$Y-12$ Central Files $(Y-12 R C)$

Oak Ridge National Laboratory

Slaughter, G. M. (2)

Ohio State University

Department of Welding Engineering

Oak Ridge $Y-12$ Plant

McCauley, R..B.

Alvey, H. E.

Paducah Gaseous Diffusion Plant

Bernander, N. K.

Bostock, D. J.

Burditt, R. B.

Burkhart, L. E.

Canary, W. W. (10)

Levin, R. W.

Sandia-Albuquerque

Davis, M. J.

Denny, A. (2)

Dodson, W. H.

Ellingson, R. D.

Gritzner, V. B.

Hemphi11, L. F.

Huber, R. A. (2)

Sandia-Livermore

Adolphson, U. R.

Brooks, J.A.

Jackson, V. C.

Mote, M. W. , Jr

In addition, this report is distributed in accordance with category UC-25, Meta7s, Ceramics, and Materials, as given in the "USAEC Standard Distribution Lists for Unclassified Scientific and Technical Reports", TID-4500. 